UNIVERSIDADE DE SÃO PAULO

FACULDADE DE CIENCIAS FARMACEL'TICAS

Curso de P6s-Graduação em

Ciência dos Alimentos

\title{
DIGESTIBILIDADE E PROPRIEDADES NUTRICIONAIS DO FEIJÃO (Phaseolus vulgaris, L.) E DE SUAS PROTEINAS ISOLADAS
}

URSULA MARIA LANFER MARQUEZ

Tese para obtenção do tiftulo de DOUTOR

Orientador:

Prof. Dr. FRANCO SJ. LAJOLO

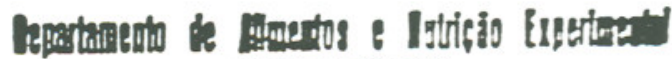

F CF / U SP

São Paulo

1988

11566 


\section{PREFACIO}

O estudo da digestibilidade e das caracteristicas bioquímicas do beijão, atē hā 20 anos, constituĩa campo de trabalho em que apenas alguns pioneiros se salientavam, dando-lhe a devida importância.

Com o desenvolvimento tecnolōgico surgiram novas "ferramentas" de trabalho e aperfeiçoaram-se outras pré-existentes, podendo-se assim verificar a complexidade do estudo bioquimico do beijão. Foram estudados os seus fatores antinutricionais, identificados os aminoācidos limitantes e ensaios em animais $e$ humanos revelaram o seu potencial nutricional.

o Prof. Franco M. Lajolo acompanhou esta evolução internacional ao criar por volta de 1973, no Departamento de Alimentos e Nutrição Experimental da Faculdade de Ciências Farmacêu ticas da USP, uma linha de pesquisa voltada ao estudo do beijäo.

Fomos introduzidos à recém-criada atividade, $e$ desde então, recebemos a constante e eficiente orientaçāo deste Mestre, podendo assim, serem implantadas técnicas analiticas e metodologias adequadas ao estudo bioquímico e nutricional do beijão e de outras leguminosas. Hoje com mais de uma dezena de teses apresentadas e inümeros trabalhos científicos publicados, sob orien- 
tação do prof. Franco M. Lajolo, nos deparamos com a formação de um grupo de pesquisadores, definitivamente ligados ao "beijäo".

Devemos, portanto, a nossa verdadeira formação profissional e universitäria ao Prof. Or. Franco M. Lajolo, a quem dedicamos os nossos mais profundos agradecimentos.

A realizaçäo deste trabalho, no entanto, não teria sido possivel, sem a colaboração dos Drs.: Siu Mui Tsai Saito, Rey naldo L. Victōrîa, Paulo Trivelin e Francisco Krug do CENA ICentro de Energia Nuclear na Agricultura, USP - Piracicabal, que nos orientaram em algumas etapas deste trabalho e nos auxiliaram na realização das anälises isotōpicas do ${ }^{15} \mathrm{~N}$ e na determinação do enxofre quimico.

Mencionam-se, contudo, os colegas do Departamento de Alimentos e Nutrição Experimental da Faculdade de Ciências Farma cêuticas da USP, e em especial os professores Marilene De vuono c. Penteado, Elizabete w. de Menezes e Maria Oriana Reyes Figueroa, por toda colaboração prestada.

Ressaltamos, tambêm a colaboração amiga e estimuladora do Prof. w. Baltes, Professor Titular do Instituto de Quimica de Alimentos da Universidade Técnica de Berlim (Rep. Fed. da Alema nhal durante o desenvolvimento desta tese.

A Srta. Celly Akemi Donomai, a quem, por sua dedicação e presteza, colaborando nas anälises quimicas e biolōgiccs, consignamos nosio reconhecimento.

Ao Dr. Eduardo A. Bulisani da Seção de Leguminosas do Instituto Agronômico de Campinas, pelo fornecimento desinteressa 
do das sementes de beijão, nossos agradecimentos.

Ao Prof. Clōvis de Araujo Peres do Instituto de Matemätica e Estatistica, agradecemos o auxîlio da interpretação es tatistica dos resultados.

A Srta. Moema Rodrigues dos Santos, bibliotecāria da Biblioteca do conjunto das Quimicas - USP, agradecemos pela revisão e normalização das reberências bibliográbicas.

A Srta. Loanda d'Eurydice, eficiente e dedicada secre tāria, nossa gratidäo.

A todos os que direta e indiretamente nos auxiliaram na realização do presente trabalho o nosso agradecimento.

A realização deste trabalho, no entanto, não boi apenas fruto da dedicação de diversas pessoas. Temos que mencionar o apoio binanceiro da Fundação Volkswagen, da Rep. Fed. da Alemanha, da FINEP, (Financidadora de Estudos e Projetos) e da ABIA (Associação Brasileira das Indūstrias de Alimentação).

Finalmente, e acima de tudo, permanece a inesquecivel lembrança do constante incentivo demonstrado pelo meu marido, Gerardo, o apoio da minha mäe, e a paciência dos meus bilhos, André, Tânia e Fābio. A eles, ofereço esta tese. 
1 - INTRODUÇÃO

pāg.

2 - REVISÃO DA LITERATURA

3 - OBJETIVOS

4 - PLANEJAMENTO

5 - MATERIAL

5.1 - Feijão

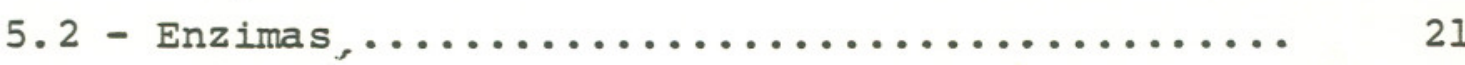

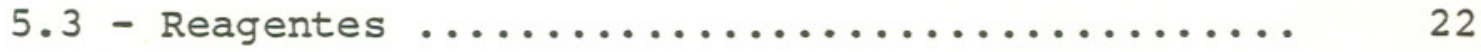

5.4 - Isótopos do nitrogênio e do enxofre ........ 22

5.5 - Obtenção de feijões marcados com ${ }^{15}{ }_{N}$ e ${ }^{35}$ s .. 22 5.5 .1 - Assimilação de compostos nitrogenados e sulfurados pela planta de feijão ..

5.5 .2 - Condições experimentais para a marcação dos feijões ............... 24

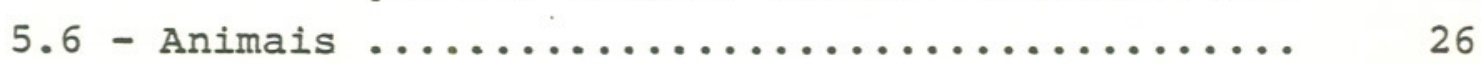

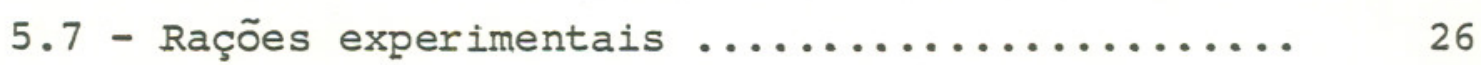

5.8 - Tratamento térmico (Cocção) ............. 27

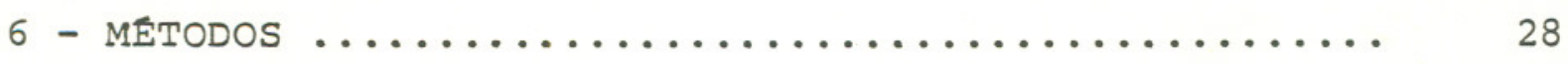

6.1 - Fisico-Quimicos e Quimicos .............. 28

6.1 .1 - Preparo das amostras ............ 28

6.1 .2 - Determinação da proteina .......... 28

6.1 .3 - Determinação dos carboidratos ...... 29 
pāg .

6.1 .4 - Determinação da fibra dietäria ...... 29

6.1 .5 - Extração e fracionamento das proteinas 29

6.1 .6 - Determinação do enxofre total ....... 31

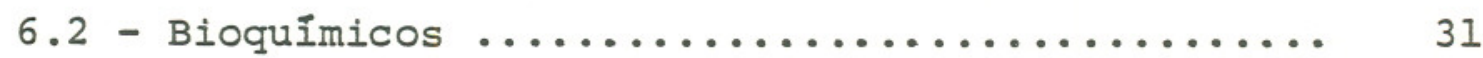

6.2 .1 - Atividade do inibidor da tripsina .... 31

6.2.2 - Atividade inibidora sobre a $\alpha$-amilase. $\quad 32$

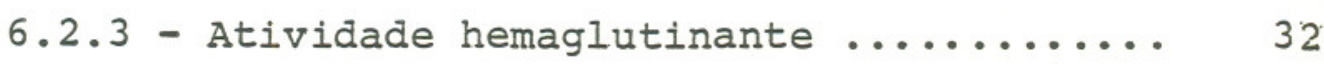

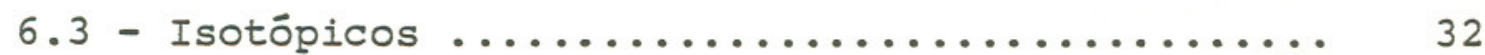

6.3 .1 - Determinação do enriquecimento $\operatorname{com~}^{15} 5_{\mathrm{N}} \quad 32$

6.3 .2 - Determinação da radioatividade do. ${ }^{35} \mathrm{~s} 33$

6.4 - Biológicos: ensaios em animais ............ 34

6.4.1 - la. Experiência: Utilização biolōgica das frações protéicas isoladas do feijão (albuminas, globulina Gl e gluteli

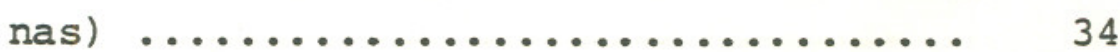

6.4 .2 - 2a. Experiência: Aproveitamento nutri cional do feijão integral, e do feijão adicionado da fração albuminica ......

6.4 .3 - 3a. Experiência: Ensaio das rações mar cadas isotopicamente. Efeito do feijão e de suas proteinas isoladas na perda de nitrogênio e enxofre fecais..

6.5 - Estatisticos ......................

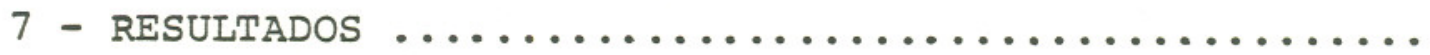

7.1 - Extração e fracionamento das proteinas do fei-

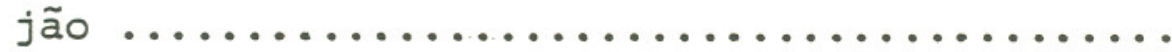

7.2 - Enriquecimento isotópico das proteinas do fei-

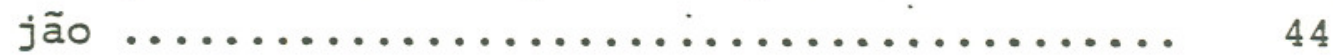

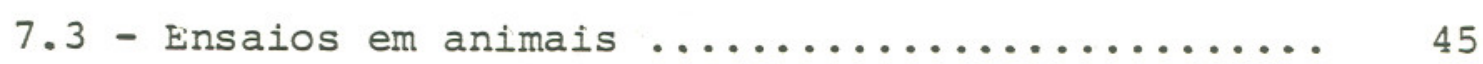

7.3.1 - Digestibilidade e Valor Nutricional .. 45

7.3 .2 - Ensaio biológico do feijão integral, al buminas e globulina Gl, marcados isoto

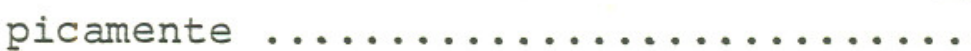


pāg .

7.3 .3 - Efeito do feijão integral, da fração al bumina e da globulina Gl na perda de

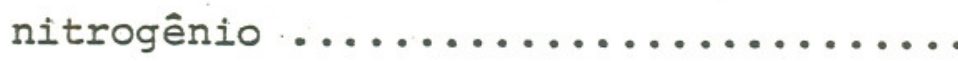

7.3.4 - Efeito do feijão integral e das fra- ções protéicas isoladas na excreção de

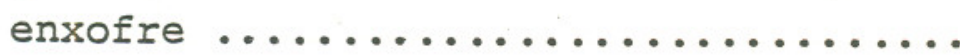

8 - DISCUSSÃO

8.1 - Propriedades nutricionais do feijão e digestibilidade de suas frações protēicas .......... 60

8.2 - Efeito do feijão integral, das albuminas e da globulina Gl, na perda de nitrogênio total e

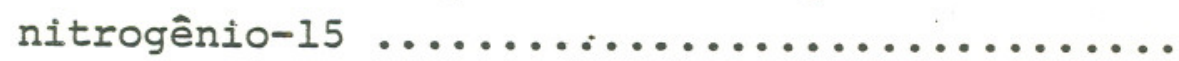

8.3 - Efeito do feijão integral, das albuminas e da globulina Gl na eliminação de enxofre .......

9 - CONCLUSÕES

10 - RESUMO/SUMMARY

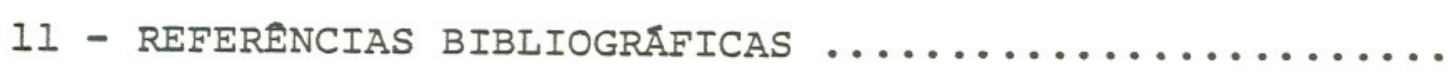

12 - APENDICE: Lista de figuras, tabelas e quadros .... 
1 - INTRODUÇÃO

Enquanto a produção e utilização de leguminosas na Eu ropa, oceania e Rússia se situam bem abaixo do seu potencial, elas constituem hoje em dia, um importante alimento protéico de origem vegetal, sendo difundidas especialmente na América, Ásia, India e Africa, onde o suprimento das necessidades protéicas ge ralmente não è coberto pelas "proteinas de alto valor biológi co".

As leguminosas incluem segundo os dados mais recentes, cerca de 740 gêneros e 16.000 a 19.000 espécies. Entretanto, apenas 20 espécies são utilizadas comumente como gênero alimentício. Entre estas os feijões, representados pelo gênero Phaseolus, se destacam pela sua grande aceitação (Kantha \& Erdman Jr., 1987). O consumo diário de feijão (Phaseolus vulgaris, L.) aqui no Brasil, é bastante elevado, situando-se ao redor de 60 gramas "per capita", e devido ao seu elevado teor protéico (em torno de 25\%), é capaz de suprir, em grande parte, as necessida des protéicas e energéticas da população, principalmente das classes sócio-econômicas menos favorecidas.

Durante os últimos 20 anos, muitos esforços tem sido feitos para suprir adequadamente as necessidades de proteinas. Iniciou-se um significativo aumento na produção de cereais como 
tambëm de leguminosas, e reconheceu-se experimentalmente que as proteinas de leguminosas, deficientes em aminoácidos sulfurados, são complementadas pelas proteinas de cereais, quando ingeridas em determinadas proporções.

Apesar desses aspectos favorāveis, diversos fatores limitam a qualidade nutricional das leguminosas. O reduzido va lor biológico dos feijões tem sido atribuido à baixa digestibilidade de suas proteínas, aliada à deficiência de aminoäcidos sulfurados, bem como à presença de fatores antifisiolögicos, tais como as antitripsinas e fitohemaglutininas, entre outros, variāveis quali e quantitativamente.

Extensas revisões sobre a importância biológica dessas substâncias indesejāveis e a sua inativação por um tratamen to térmico adequado, deixaram claro que esses fatores já descri tos, não são os unicos responsāveis pela baixa utilização biológica. Por outró lado, vārios pesquisadores sustentam a hipótese da reduzida digestibilidade estar relacionada com uma maior excreção de nitrogênio de origem metabōlica, falseando os dâ dos relativos à absorção de nitrogênio, determinada atravēs de métodos convencionais de anālise química.

O trabalho procurou explorar este ângulo da pesquisa, trazendo informações sobre a digestibilidade real do feijão e de suas principais frações p:otéicas. 
2 - REVISÃO DA LITERATURA

\section{1 - Digestibłlidade e valor biológico do feijão}

Estudos em animais situam a digestibilidade das proteinas do feijão ao redor de 70-80\%, mesmo após um aquecimento apropriado (Bressani e Elias, 1984; Durigan et al., 1987; Evans \& Bauer, 1978; Hernandez-Infante et al., 1979). Esses estudos no homem, revelaram uma digestibilidade ainda menor daquela encontrada em animais (Bressani et al., 1982; Navarrete \& Bressa ni, 1981), acompanhada de uma elevada excreção fecal de nitrogênio (Calloway \& Kretsch, 1978; Graham et al., 1979).

o reduzido valor biológico e nutricional dos feijões tem sido atribuỉdo tanto à deficiência em aminoácidos sulfurados, como à presença de fatores antifisiológicos. A importância dos inibidores de proteases e amilases, hemaglutininas e fatores de flatulência, foi amplamente revista na literatura ci entifica (Jaffē, 1980; Lajolo, 1977; Laskowski \& Kato,1980; Richardson, 1980-1981; Gallaher \& Schneeman, 1984; Liener, 1986 ; Menezes \& Lajolo, 1987; Reddy et al., 1984).

Embora o tratamento tērmico inative uma boa porcentagem dessas substâncias indesejāveis, o coeficiente de digestibi lidade das leguminosas permanece reduzido, sugerindo haver ou- 
tros fatores envolvidos com a baixa utilização biológica.

Alguns autores atribuiram a reduzida digestibilidade do feijão ao conteúdo em taninos e compostos fenōlicos existentes na casca, por serem termorresistentes e capazes de se ligarem a proteinas ou a outros componentes da semente, formando com plexos indigeriveis "in vitro" (Artz et al., 1987; Aw \& Swanson, 1985; Laurena et al., 1986) e mesmo "in vivo" (Bressani et al., 1977; Bressani et al., 1982; Deshpande \& Pradesh, 1986; Elias et al., 1979; Ronnencamp, 1977). Outra possibilidade è a da inibi ção direta de enzimas digestivas, pela ação de substâncias fenō licas (Fernandez, 1978; Griffiths \& Moseley, 1980; Singh, 1984). Já em 1950, Jaffé, encontrou valores de 76,8, 79,5 e 84,1\% para a digestibilidade do feijão (Phaseolus vulgaris, L.) preto, ver melho e branco respectivamente, relacionando o decréscimo da digestibilidade com o aumento no conteúdo de compostos fenóli cos e com a cor.

Bicudo, em 1978, relatou que a remoção da casca do feijão, anteriormente à cocção, aumentava significativamente a digestibilidade e a sua utilização protēica líquida em ensaios realizados com ratos.

Os valores dessas variäveis passaram respectivamente de 66,7 para 76,0 e de 45,1 para 60,0 . Da mesma forma, a adição da cascé de feijão à dietas de caseina afetou negativamente a sua utilização, diminuindo tambēm a digestibilidade. No entanto, a remoção de $90 \%$ dos compostos polifenólicos presentes na casca, atravēs de extrações sucessivas, e a adição dessas cascas à dietas de caseina, não mostrou o efeito benéfico espe- 
rado, sugerindo o autor, que esse mecanismo não seria o único responsāvel pela reduzida digestibilidade.

Vários autores relacionaram o reduzido aproveitamento biológico dos feijões, não somente com a baixa digestibilidade das proteinas, mas especificamente com a reduzida digestibilida de e biodisponibilidade dos aminoäcidos essenciais. Informações sobre a biodisponibilidade dos aminoäcidos sulfurados são escas sas: em feijões da espécie Vicia faba por exemplo, a digestibilidade "verdadeira" da cisteina (52-66\%) foi consideravelmente in ferior a do nitrogênio (79-83\%) sendo a medida feita através da recuperação do aminoácido ao nỉvel do segmento ileo-intestinal em porcos (Ivan \& Bowland, 1976). O efeito benéfico causado pe la suplementação das proteinas de feijão com aminoãcidos sulfurados e outros aminoácidos limitantes, tem sido demonstrado por vărios pesquisadores (Antunes et al.; 1979; Bressani \& Elias, 1976; Bressani et al., 1963; Hernandez-Infante et al.; 1979; Moraes e San tos \& Dutra de Oliveira, 1972; Sgarbieri \& Whitaker, 1982.

Em 1978, Evans \& Bauer confirmaram a reduzida utiliza ção dos aminoácidos sulfurados e mostraram, atravēs de uma tēcnica de balanço metabölico, que os animais absorvem $50 \%$ da metionina e $41 \%$ da cisteina provenientes do feijão, sendo porém a metionina suplementar adicionada, totalmente absorvida.

$$
\text { Sgarbieri et al. (1979), Antunes \& Saarbieri (1979) e }
$$

Durigan et al., (1987) atribuem à metionina uma disponibilidade biológica ainda menor, mas variável em função da variedade do feijão, do tempo e das condições de armazenamento.

Recentemente, Sarwar \& Peace (1986) tambēm demonstra- 
ram que a digestibilidade de aminoácidos limitantes em feijões, ervilhas e lentilhas era consideravelmente inferior à digestibi lidade do nitrogênio total, recomendando que a digestibilidade da proteina não fosse tomada como indicador da biodisponibilida de de todos os aminoácidos essenciais, indistintamente.

\section{2 - Quimica das frações protéicas do feijão}

As proteinas de leguminosas são de natureza complexa e assumem funções de reserva, metabólicas ou estruturais. Atra vês de técnicas de isolamento e fracionamento, baseados em dife renças de solubilidade, identificaram-se dois tipos de globulinas, consideradas as principais proteinas de reserva do feijão. A globulina Gl, solúvel em soluções salinas de concentração ele vada $(\mathrm{NaCl} 0,5 \mathrm{M})$ e a globulina $\mathrm{G} 2$, solúvel mesmo em concentra ções salinas muito reduzidas (Sun \& Hall, 1975).

A fração globulinica predominante no feijão, tem sido referida na literatura por värias denominações: globulina Gl, glicoproteina II, phaseolina, vicilina, componente a e por fração E, gerando certa confusão (Barker et al., 1976; Derbyshire et al., 1976; Mcleester et al., 1973; Pusztai \& Watt, 1970 ; Ishino \& Ortega, 1975; Seidl et al., 1969). Apesar das diferen ças encontradas nessas preparações, elas parecem possuir a mesma identidade e serão referidas por nōs, daqui em diante, pelo termo globulina Gl, como descrita originalmente por McLeester et al., 1973 e Sun \& Hall (1975).

A fração albuminica, solúvel em água se constitui nu- 
ma mistura, incluindo proteỉnas com atividade enzimática, fa tores antinutricionais e possivelmente componentes com função de reserva. Schroeder (1984) relata que as albuminas presentes nos cotilēdones de ervilhas são degradadas durante a germinação da semente, possuindo portanto uma função de reserva, similar à das globulinas. Esta fração tem sido encontrada no feijão em concentrações variāveis, de 14 a $31 \%$ da proteina total (Lanfer Marquez \& Lajolo, 1981; Sathe \& Salunkhe, 1981; Sgarbieri et al., 1979). Essas discrepâncias nos valores encontrados para a fração albuminica, foram atribuidas por Bhatty (1982) a contami nação cruzada de proteinas solúveis em água e em soluções salinas.

Nesse sentido, Desphande \& Nielsen (1987a) julgam di fícil uma quantificação do teor de albuminas "verdadeiras" em leguminosas, uma vez que mesmo a globulina Gl è parcialmente so lubilizada em extrações com água, sendo a quantidade extraỉa , variāvel em função da variedade do feijão.

Alēm dessas três frações protēicas, foi descrita em feijões, a presença de outras, insolúveis em soluções salinas, como è o caso das glutelinas e prolaminas (Lanfer Marquez, 1979 e Ma, 1977).

Estudos relacionados com a composição de aminoácidos dessas frações protéicas, moscraram que as globulinas são deficientes em aminoácidos sulfurados, apesar dos teores encontra dos terem sido discrepantes. A maior parte dos aminoácidos sul furados presentes no feijão, parece estar concentrada na fração albuminica, que engloba tambëm a maioria dos fatores antinu 
tricionais (Barker et al., 1976; Bradbear \& Boulter, 1984; Chang \& Satterlee, 1981; Lanfer Marquez \& Lajolo, 1981; Liener \& Thompson, 1980). Em outras espécies, como é o caso do "Phaseolus mungo" por exemplo, Padhye \& Salunkhe (1979) relataram um cômputo químico dos aminoácidos sulfurados de 64,$0 ; 0,0 ; 56,0$ e 70,7, para a albumina, globulina, prolamina e glutelina, respec tivamente.

Esses resultados mostram no seu conjunto, haver uma predominância maior ou menor de aminoäcidos sulfurados nas proteinnas solúveis em água, apesar da problemática relacionada com a separação das frações protēicas, comentada anteriormente.

2.3 - Digestibilidade das frações protēicas isoladas "in vitro"

As possiveis diferenças na digestibilidade "in vitro" das frações protéicas isoladas do feijão, jã foram assunto de diversos trabalhos. Assim a fração Gl, proteina predominante no feijão, representando mais de $50 \%$ da proteina total (Romero et al., 1975), mostrou-se altamente susceptivel à digestão por enzimas proteolíticas, após um tratamento tērmico adequado (Brad bear \& Boulter, 1984; Desphande \& Nielsen, 1987b; Lanfer Mar quez, 1979, Liener \& Thompsun, 1980; Romero \& Ryan, 1978; Vaintraub et al., 1979).

Embora a maioria dos estudos tenha mostrado uma boa digestibilidade da globulina Gl, seidl et al. (1969), reporta- 
ram que a fração globulinica do feijão preto (Ph. vulgaris), é resistente ao ataque enzimático por diversas enzimas proteolíti cas, mesmo após o aquecimento. Vaintraub \& Sayanova (1977) atri buem esse fato, à presença de teores significativos de inibidores de proteases, uma vez que o tratamento tërmico foi relativa mente brando (solução protéica a $1 \%$ em tampão fosfato 0,1M, pH 7,0, em banho-maria fervente). Trabalhos recentes, realizados por Desphande \& Nielsen (1987b. e c) evidenciaram uma efetiva hi drólise "in vitro" da phaseolina ou fração Gl, aquecida, por diversas enzimas proteoliticas inespecificas num prazo de apenas 30 minutos, levando à formação de polipeptídeos de baixo pe so molecular. Por outro lado, a hidrölise, dessa proteína "in vitro" por tripsina e quimotripsina è grandemente influenciada pela proporção enzima : substrato e pela presença de inibidores enzimāticos termorresistentes.

Enquanto a literatura é mais ou menos concordante em relação à elevada digestibilidade da globulina Gl do feijão, os resultados relacionados com a fração albuminica tem evidenciado um comportamento variável frente à ação de enzimas proteolíti cas.

Sathe et al. (1982), trataram frações protēicas isola das do "Great Northern bean" com uma combinação de peptidase, tripsina e alfa-quimotripsina, medindo a liberação de grupos aminicos com TNBS (ácido trinitrobenzenosulfônico). A digestibilidade das proteinas da farinha do feijão, albuminas, globuli nas, concentrado protéico e isolado protéico sem aquecimento foi baixa, da ordem de 9,$30 ; 2,73 ; 10,09 ; 13,60$ e 28,59\%, respectivamente. O aquecimento a seco elevou a digestibilidade para 
68,$58 ; 24,05 ; 29,67 ; 24,05$ e $34,31 \%$ respectivamente, tendo os autores conseguido valores mais elevados com $\circ$ aquecimento por via úmida.

Ao contrário dos resultados encontrados por Sathe et al. (1982), Lanfer Marquez \& Lajolo (1981) trataram as frações protēicas isoladas de feijão (albuminas, globulina Gl, globulina G2 e glutelinas) com tripsina, pancreatina e pepsina seguida de pancreatina; verificaram que o aquecimento elevava a liberação de alfa-amino grupos, tanto nas globulinas como nas glu彑 telinas; porém a fração albumina aquecida, era formada de agre gados de alto peso molecular, apresentando uma digestibilidade inferior em relação à albumina nativa. A explicação encontrada foi de um impedimento estérico ou de um bloqueio de resíduos de aminoācidos dificultando a ação enzimática, sendo que a possibilidade do envolvimento de fenöis ou quinonas, livres ou complexadas com a prọteina, não podia ser excluida. De fato, agre gados de alto peso molecular eram formados pelo aquecimento, não penetrando no gel de poliacrilamida. Peptideos com um peso molecular de 14.000 a 20.000 permaneciam no resíduo, apōs a diges tão da albumina autoclavada. Estes resultados estão de acordo com a reduzida biodisponibilidade dos aminoácidos sulfurados, já comentada anteriormente.

Desphande \& Nielsen, em 1987c, examiraram, por eletro forese em gel de poliacrilamida, sódio-dodecilsulfato, a hidrölise enzimätica de extratos de feijão integral e das proteinas solúveis em água e soluções salinas, de 11 cultivares de $\underline{\mathrm{Ph}}$. vulgaris. A hidrólise do feijão integral era dependente da 
variedade, mas altamente influenciada pela razão proteina:enzima. A fração globulina era fácil e completamente hidrolisada, e a fração solúvel em água, apresentou apōs o tratamento térmico, um comportamento semelhante ao descrito por Lanfer Marquez e Lajolo (1981) onde durante o aquecimento foram formados agregados protéicos dé peso molecular muito elevado, incapazes de serem degradados pela tripsina.

2.4 - Ensaios biológicos das frações protēicas isoladas

Enquanto a digestibilidade "in vitro" è regularmente citada pela literatura cientifica, poucos são os trabalhos rela tando ensaios biológicos com proteinas isoladas do feijão, e destes, a maioria se refere apenas à globulina Gl.

Apesar da boa digestibilidade da fração globulinica aquecida $(92,5 \%)$, levemente inferior à da caseína $(95,1 \%)$, Liener \& Thompson (1980), observaram um reduzido crescimento de ratos quando alimentados com essa fração. Alēm deste estudo "in vivo", conduzido durante 4 semanas, outros autores observaram tambēm a sua elevada digestibilidade (Bradbear e Boulter, 1984; Navarrete \& Bressani, 1981; Vaintraub et al., 1979) . Apenas Pusztai e Palmer (1977) relataram que uma globulina isolada de feijão, isenta de lectinas, não inibia o crescimento de ratos. Esta conclusão, no entanto, se baseou em experimen tos, nos quais a globulina Gl era acrescentada num teor de apenas $0,5 \%$ a uma dieta de caseina $(5 \%)$. 
Antunes \& Sgarbieri (1980) em ensaios com animais, obtiveram reduzido aproveitamento biológico de extratos protéi cos totais, albuminas e globulinas.

Outros (Sgarbieri et al., 1982), relataram que a frạ ção Gl não aquecida, oferecida a ratos em jejum, atravēs de uma dose ünica por intubação, era digerida em 80-90\%. No entanto, ocorria uma produção aumentada de secreções intestinais contendo um teor relativamentè elevado de nitrogênio. Este ni trogênio não reabsorvido, reduzia então a digestibilidade aparente da fração $G 1$ para $35 \%$.

$\mathrm{Na}$ verdade, pouco se sabe sobre as razões do reduzido valor biológico da globulina Gl. Uma das causas está relacionada com a deficiência em aminoácidos sulfurados. Apesar da elevada digestibilidade "in vitro", a ingestão da globulina aquecida é capaz de provocar além do reduzido crescimento, uma hipertrofia pancréática nos animais, geralmente observada na presença de proteína não digerida. Uma explicação alternativa seria supor uma perda de proteina de origem endógena na forma de enzimas pancreāticas.

2.5 - A secreção e excreção de nitrogênio enđógeno

A reduzida "digestibilidade aparente" de leguminosas, observada "in vivo" tanto em animais como humanos, alēm das causas citadas anteriormente, pode ter uma explicação alternativa, atravēs de um aumento da secreção de nitrogênio endógeno, 
estimulado por algum mecanismo ainda não totalmente elucidado (Slump \& Van Beck, 1975; Costa de Oliveira \& Sgarbieri, 1986b).

Diversos trabalhos falam a favor dessahipötese. Amos tras contendo elevados' teores de nitrogênio endógeno, coleta das no intestino de ratos, foram observados por Nasset e Ju (1961), Nasset (1972) e Kohler et al. (1984). Estas secreções endōgenas são de digestão mais lenta do que as proteinas da dieta estendendo-se a sua hidrốlise ao longo do trato gastro-intestinal (Partridge et al., 1985) causando uma significati va diluição do nitrogênio da dieta pelo nitrogênio endógeno.

$\mathrm{Na}$ verdade, esse efeito pode ser causado tanto por uma secreção pancreātica aumentada, apōs a ingestão de proteî nas de leguminosas (Green \& Nasset, 1983) como por algum mecanismo que impede a reabsorção desse nitrogênio enđógeno.

A excreção de nitrogênio enđögeno, na forma de enzimas digestivas, déscamações da mucosa intestinal e bactērias da flora intestinal, dificulta a interpretação dos resultados da anālise do nitrogênio fecal. A denominada "digestibilidade aparente" ignora o nitrogênio metabólico presente nas fezes e não' representa um indice adequado para estimar a digestibili dade verdadeira da proteina. Por outro lado, a "digestibilida de real" pelo método clássico de Mitchell (1924), avalia o nitrogênio endógeno, atravēs da excreção de nitrogênio de um gi po paralelo de animais sob dieta aprotéica. No entanto, esta correção nem sempre é adequada, pois parece haver influência da natureza do alimento e da concentração protēica ingerida, na taxa de excreção endógena. 
Segundo Mitchell e Bert (1954) a proteina isolada, não exerce um efeito significativo, sendo o nitrogênio endögeno excretado, normalmente reduzido, e da ordem de $3 \mathrm{mg} / \mathrm{rato}$ de $50 \mathrm{~g} /$ /dia. No entanto, baseado na literatura, parece haver umá correlação entre a concentração de componentes indigeriveis e nãonitrogenados da ração, com o nỉvel de excreção de nitrogênio endógeno, como veremos.

Krawielitzki e cols:; em estudos sucessivos empregando isótopos, demonstraram haver um aumento do nitrogênio endóge no, proporcional à ingestão de proteina. As dietas oferecidas aos animais, por estes autores, consistiam, no entanto, de ceva da, levedura e soja, e não de proteínas isoladas. Assim, por exemplo, a ingestão de lo0mg N/dia proveniente de uma ração a base de leveduras causou em ratos, um excreção de nitrogênio endógeno de $16,62 \mathrm{mg} \mathrm{N} /$ dia. Animais alimentados com 200, 300 e $400 \mathrm{mg}$ N/dia, tiver̦am uma participação do nitrogênio enđógeno mai or, da ordem de $17,37,25,41$ e $35,26 \mathrm{mg}$ N/dia, respectivamente (Krawielitzki \& Bock, 1976; Krawielitzki \& Tim, 1978; Krawielitzki et al., 1981).

Zebrowska e Low (1987), estudanḍo a variação da secreção pancreātica exócrina em função do tipo e da quantidade de fibra dietária, concluiram a fração não celulósica da fibra ser responsável pelo aumento do volume da secreção pancreática.

Da mesma forma, alimentos ricos em compostos polifenó licos, devem ser vistos com cautela, por serem capazes de elevar a excreção de nitrogênio de origem endógena (Tamir e Alumot, 1970). 
Outros estudos relacionaram a elevada excreção de nitrogênio com um aumento da proliferação bacteriana. Na verdade, este efeito não è especîfico para os feijões, mas parece ocorrer com outras dietas, ricas em polissacarídeos não-digeríveis (Salter, 1983, Liebert \& Gebhardt, 1986). A literatura concernente indica que a atividade microbiana, e paralelamente, a retenção de nitrogênio, são influenciadas pelo tipo e teor de car boidratos, bem como pelo teor de fibra presente na dieta. No entanto, os efeitos de carboidratos indigeriveis sobre a excreção de nitrogênio endögeno e o seu envolvimento com a sintese protéica microbiana são complexos e ainda não podem ser generalizados, necessitando de mais estudos (Dreyer \& van der Walt, 1984; Kreuzer \& Kirchgessner, 1985).

Costa de Oliveira \& Sgarbieri (1986a), mostraram que ratos injetados com ${ }^{14}$ C-glicina e alimentados por 4 dias com cá seina, feijões cozidos ou crus, excretaram 2, 5 e 10 vezes mais radioatividade e $\mathrm{N}$ endógeno, respectivamente, em relação àqueles que ingeriram a ração aprotéica. O cālculo da quantidade de $\mathrm{N}$ endógeno foi baseado na premissa de haver uma marcação isotōpi ca semelhante entre $\circ \mathrm{N}$ endögeno excretado a partir das rações experimentais e a ração aprotéica.

Em outro trabalho, Costa de Oliveira \& Sgarbieri (1986b) utilizando feijão integral e o seu extrato protéico total autoclavados, verificaram que as digestibilidades e os valo res biológicos calculados a partir do balanço entre ${ }^{15} \mathrm{~N}$ ingerido e excretado eram superiores àqueles baseados no balanço do N total. 
Por outro lado, Bender e Mohammadiha (1981) e Sandaradura e Bender (1984), acreditam que as elevadas excreções de DNA e nitrogênio, observadas em ratos alimentados com feijões co zidos, se devem a um aumento no "turnover" das células da mucosa intestinal. Esta afirmação foi baseada na determinação do número de bactēriás fecais viāveis e na contagem do número de mitoses celulares nas criptas intestinais de ratos, após injeção intraperitoneal de colchicina. No entanto, a medida. do "turnover" da timidina- ${ }^{3} \mathrm{H}$ realizada por outros autores (Fairweather-Tait et al., 1983) mostrou que a alimentação de ratos com feijōes cozidos provocava apenas um moderado aumento da des camação das células da mucosa, atribuindo o efeito da elevada ex creção fecal não somente à um aumento na descamação da mucosa intestinal mas tambēm à presença de carboidratos indigeríveis, que por sua vez podem incrementar a excreção de $\mathrm{N}$ por via endögena.

Resultados concordantes com uma reduzida contribuição da descamação celular foram descritos anteriormente por Da Costa et al. (1971), mostrando que apenas 8-15\% da proteina secretada pelo intestino delgado, são provenientes de descamação celulares.

Parece que o nitrogênio fecal è um complexo representado por nitrogênio de origem exógena e endógena em proporções variāveis, dificilmente determinadas, podendo a sua composição e estrutura serem modificadas significativamente pela ação da flo ra microbiana intestinal (Souffrant et al., 1986).

As informações apresentadas, permitiram supor que a 
reduzida utilização biológica do feijão poderia estar relacionada diretamente com a resistência à digestão de algumas das frações protéicas "per si" ou a um complexo resultante da interação dessas frações com outros componentes do feijão durante o cozimento. Nesse contexto parecia importante tambēm, determi nar quanto do nitrogênio fecal era proveniente da proteína do feijão e quanto tinha origem indireta ou endógena. 
3 - OBJETIVOS

A investigação aqui relatada teve como objetivos espe cificos:

3.1 - Determinar a digestibilidade e a utilização biolögica do feijão e de suas frações protēicas isoladas em ensaios com ratos.

$3 . \dot{2}$ - Avaliar, atravēs do emprego de proteinas marcadas, a contribuição do nitrogênio e enxofre de origem endóge na, nas perdas fecais causadas pela ingestão do feijão ou de suas frações protéicas. 
4 - PLANEJAMENTO

O planejamento proposto a seguir foi desenvolvido em vărias etapas sucessivas, no sentido de se poder obter informações de complexidade crescente sobre a digestibilidade do fei jão e de suas principais frações protēicas.

Inicialmente, procedemos à extração e isolamento das principais frações protēicas do feijão (albuminas, globulina GI e glutelinas). A seguir foram realizados os ensaios biológi cos em ratos, com a finalidade de avaliar a digestibilidade do feijão integral bem como de cada uma das frações protéicas isoladas, visando exṕlicar algumas de suas propriedades nutricio nais. A anālise e interpretação dos resultados assim obtidos, foram realizados primeiramente através de metodologia convencio nal, baseada nos ganhos de peso e na razão entre o nitrogênio in gerido e excretado por via fecal. Mas, sō por esse "balanço" se ria dificil determinar a origem do material fecal, pois não são reconsiderados ai, os processos metabólicos de absorção e secreção inerentes à fisiologia do aparelho gastro-intestinal, os quais alteram significativamente a sua composição. Daí, planejarmos utilizar "material marcado" como técnica mais especifica, nos ensaios biológicos em ratos. 
mente atravēs da marcação das suas proteinas com nitrogênio-15 e enxofre-35. Após a colheita destes feijões marcados e do isolamento das suas principais frações protéicas, essas foram ensaidas em ratos, agrupados de acordo com a dieta recebida. Um grupo recebeu o feijão integral, outro a fração albumina e um terceiro a fração globulina Gl. Incluimos ainda dois grupos controles: um com caseína e outro aprotéico.

Essa metodologia permitiu obter, assim, informações sobre a origem do nitrogênio-15 e do enxofre-35 excretados, podendo assim diferenciar sua origem, se endögena ou exógena. 
5 - MATERIAL

$$
5.1-F e i j a ̃ o
$$

Estudamos sementes da variedade Carioca, espécie phaseolus vulgaris, L. provenientes da Estação. Experimental do Ins tituto Agronômico de Campinas, SP, onde foram cultivadas em con dições controladas.

\section{2 - Enzimas usadas}

Tripsina de pâncreas bovino (tipo III, 2 x cristaliza da), Pancreatina de pâncreas de porco (grau VI, 4 X NF), e Pepsina de mucosa de estômago de porco (P7012) da Sigma Chemical Co. Alfa-Amilase termoestável - Termamyl-120I da Novo Industri AS.

Amilase salivar (1,4-alfa-D-glucano hidrolase EC 3.2.1.1) foi obtida de saliva humana, purificada por precipita ção fracionada com acetona, de acordo com a técnica descrita por Finardi Filho \& Lajolo (1982). 
5.3 - Reagentes

Albumina sērica bovina ( 2 x cristalizada), BAPA (benzoilarginina-p-nitroanilida), ácido 3,5, di-nitrosalicilico, POPOP (1,4-di-2-(5-feniloxazol) benzeno, PPO (2,5 difeniloxazol) foram obtidos da Sigma Chemical Co.; naftaleno da Merck; etilenoglicol da Baker; os demais reagentes utilizados foram de grau analitico.

5.4 - Isótopos do nitrogênio e do enxofre

o cloreto de amônio enriquecido com nitrogênio-15

$\left(10,5\right.$ átomos \& de $\left.{ }^{15} \mathrm{~N}\right)$ foi produzido e cedido gentilmente pelo CENA (Centro de Energia Nuclear na Agricultura - USP, Piracicaba, SP).

O sulfato de sódio radioativo $\left({ }^{35} \mathrm{~S}\right)$ de pureza isotópi ca de no minimo 99,998, livre de carregador, foi adquirido do IPEN (Instituto de Pesquisas Energéticas e Nucleares) São Pau10 .

5.5 - Obtenção de feijões marcados com ${ }^{15}{ }_{N}$ e ${ }^{35} \mathrm{~S}$.

5.5.1 - Assimilação de compostos nitrogenados e sulfux rados pela planta de feijão.

Embora não fosse o escopo central deste trabalho, es- 
tudar a metabolização de compostos nitrogenados e sulfurados no feijoeiro, achamos interessante citar alguns resultados obtidos por vários autores sobre a sua fisiologia.

Durante a germinação da semente e após a exaustão do nitrogênio de reserva, a planta depende das raizes para a obtenção de nitrogênio, na forma de $\mathrm{NO}_{3}^{-}$ou $\mathrm{NH}_{4}^{+}$do solo, ou de $\mathrm{NH}_{4}^{+}$proveniente da fixação de nitrogênio nos nödulos radi culares. O crescimento da planta obriga o vegetal a transpor tar o nitrogênio aos örgãos em formação, e posteriormente às sementes, devendo ser incorporado numa forma orgânica para pre venir a sua ação tóxica (Miflin, 1980).

A maioria das informações sobre os mecanismos de trans porte do nitrogênio, foram obtidas pela análise do exsudato co letado de raizes e caules cortados.

Leguminosas noduladas, podem ser classificadas em dois grupos com rélação ao seu mecanismo de assimilação e trans porte de nitrogênio. Nas leguminosas de clima temperado, tais como "alfafa" e "tremoço" o nitrogênio é transportado princi palmente através de amidas (asparägina e glutamina), enquanto que nas leguminosas de origem tropical, incluindo o feijão Phaseolus vulgaris, L., ocorre a assimilação e transporte do nitrogênio atravēs de ureídeos (alantoina e ácido alantóico) (Tri plett, 1986). Este mecanismo, em sojz e "cowpea" (Vigna un guiculata, L.) parece ser responsável pelo transporte de mais de $90 \%$ do nitrogênio, sendo estas substâncias utilizadas como substrato para a sintese protéica em órgãos aéreos da planta (Herridge et al., 1978; Schubert, 1981). 
Quanto à assimilação e metabolização do enxofre, o sulfato parece ser a fonte mais frequente para a sintese de compostos sulfurados essenciais, entre eles; a cisteina, a me tionina e a glutationa (Miflin, 1980).

Os vegetais absorvem o sulfato pelo sistema radicu lar, sendo transportado através do xilema até os órgãos clorofilados, onde è reduzido e incorporado em L-cisteína numa rea ção luz dependente. A L-cistëina representa o principal precursor de outros compostos sulfurados, sendo os aminoácidos, portadores de $90 \%$ do enxofre total da planta (Miflin, 1980).

\subsection{2 - Condições experimentais para a marcação dos feijōes}

Para a realização dos ensaios biolögicos em ratos, foi necessārio obter uma quantidade suficiente de feijão marcado para se isolar as suas principais frações protēicas e Incorporā-las nas rações para os animais.

Sementes de feijão contendo nitrogênio-15 e enxofre-35 foram obtidas atravēs de uma marcação por via radicular, pe la adição de soluções de ${ }^{15} \mathrm{NH}_{4} \mathrm{Cl}$ e $\mathrm{Na}_{2}{ }^{35} \mathrm{SO}_{4}$ à terra de cultivo.

Inicialmente foram feitos ensaios para se estabele cer as condições de marcação, as quais permitissem um enriquecimento satisfatörio em ${ }^{15} \mathrm{~N}$ e particularmente em ${ }^{35} \mathrm{~s}$ por causa 
da curta meia-vida desse isótopo (87 dias). Deve-se lembrar que na época da colheita ( \pm três meses apōs o plantio), a radio atividade do ${ }^{35} \mathrm{~S}$ já havia decaỉa uma meia-vida.

Apōs essas experiências preliminares, estabelecemos a forma de marcação, que descrevemos abaixo.

Foi preparado um canteiro coberto de $105 \times 390 \times 15 \mathrm{~cm}$ contendo terra roxa extruturada. Os feijões (Phaseolus vulgaris, L.) variedade Carioca foram semeados aos pares, com espaços de $10 \mathrm{~cm}$ e em linhas distanciadas de $25 \mathrm{~cm}$. Contamos nesta fase com a colaboração do CENA (Centro de Energia Nuclear na Agricultura, USP, Piracicaba, SP).

o plantio foi efetuado na época mais quente do ano, exigindo uma rega 2 vezes ao dia.

A adubação radicular realizada na época do plantio foi feita com uma solução $10,0 \%$ de $\mathrm{NH}_{4} \mathrm{Cl}$, contendo 10,5 átomos $\%$ de ${ }^{15} \mathrm{~N}$. Ao total foram aplicados uniformemente $67,5 \mathrm{~g}$ de $\mathrm{NH}_{4} \mathrm{Cl}$.

Concomitantemente foram aplicados aproximadamente $0,5 \mathrm{~m} i$ de $\mathrm{Na}_{2}{ }^{35} \mathrm{SO}_{4}$, com uma pureza isotópica de no minimo 99,99\% di luỉos em 2 litros de água destilada (concentração final de $\mathrm{Na}_{2} \mathrm{SO}_{4}$ na solução $=0,25 \mu$ molar $)$.

Na época prē-florescimento ( 5 semanas apōs 0 plantio) a adubação isotópica radicular foi complementada por uma adubação foliar, pulverizando-se em dias alternados aproximadamente $400 \mathrm{ml}$ de uma solução de ${ }^{15} \mathrm{NH}_{4} \mathrm{Cl}$ a $2 \%$ na la. aplicação e a $1 \%$ nas 5 aplicações subsequentes. Ao total foram aplicados $21,4 \mathrm{~g}$ de ${ }^{15} \mathrm{NH}_{4} \mathrm{Cl}$. A colheita das sementes secas, 15 semanas 
após o plantio, forneceu $1000 \mathrm{~g}$ de feijões.

A adubação com ${ }^{15} \mathrm{~N}$ via radicular e por pulverização fo liar, resultou em 0,526 átomos de ${ }^{15} \mathrm{~N}$ em excesso no feijão inte gral, 1,124 ätomo \% de ${ }^{15} \mathrm{~N}$ em excesso na fração albuminica e de $0,480 \%$ na fração globulina após mistura do feijão integral e da fração globulina com $50 \%$ da mesma fonte protēica, não marcada. Da mesma forma, a marcação com o isótopo radioativo enxofre-35 por via radicular, foi suficiëte e acompanhou o teor de enxo fre total em cada fração protéica, mantendo-se constante a rela ção entre o teor de enxofre total e a atividade do enxofre-35.

\section{6 - Animais}

Foram utilizados ratos machos ou fêmeas (Rattus norvegicus, var. albinus) da linhagem "Wistar", recēm-desmamados, obtidos a partir de colônias mantidas no biotērio da Faculdade de Ciências Farmacêuticas da USP, com rações comerciais.

\section{7 - Rações experimentais}

As dietas para as experiências foram formuladas para conterem 10\% de proteina, fornecida pela caseina (Grau far macêutico - USP), pelas sementes de feijão ou pelas suas proteinas isoladas. A ração à base de caseina foi suplementada com $0,1 \%$ de DL-metionina. As dietas continham ainda, 8\% de óleo de 
soja, 4\% de mistura salina, $1 \%$ de celulose, $1 \%$ de mistura vitaminica e amido suficiente para completar 100\%. As misturas salinas e vitaminicas foram preparadas conforme as necessidades de ratos (Institute of laboratory animal resources, 1979). A adição de caseina, feijão integral ou proteinas isoladas do fei jão era feita às expensas do amido.

\section{8 - Tratamento tērmico (Cocção)}

Antes da sua incorporação na ração, os feijões inteiros foram autoclavados a $120^{\circ} \mathrm{C}$ durante 30 minutos após a adição de ãgua na proporção 1:5 (feijão-ăgua), secos juntamente com a água de cozimento em estufa ventilada a $45^{\circ} \mathrm{C}$, durante $36 \mathrm{~h}$ e moídos para passarem uma malha de $0,25 \mathrm{~mm}$ de abertura. As frações protéicas isofladas foram autoclavadas em condições idênticas e liofilizadas. 


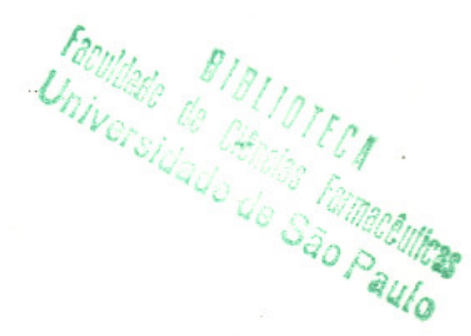

6 - METODOS

$$
6.1 \text { - Fisico-Químicos e Químicos }
$$

6.1 .1 - Preparo das amostras

Tanto as sementes de feijões "frios" como as marcadas isotopicamente foram moídas em moinho de martelos (Lab. pulverí zing Mill, Weber Bros \& White Metal Works) atē passarem uma matha de $0,25 \mathrm{~mm}$ de abertura.

6.1 .2 - Determinação da proteỉna

o nitrogênio total foi determinado pelo mētodo de micro-Kjeldahl (AOAC, 1975) utilizando-se (na conversão do nitrogênio em proteina) o fator 6,25 para as amostras biológicas e 5,7 para as demais (Sosulski \& Holt, 1980). Nos extratos pro téicos mpregou-se ainda o método de Lowry et al. (1951). 


\section{1 .3 - Determinação doś carboidratos}

Foram dosados pelo método de Dubois et al. (1956), uti lizando-se para o cálculo, uma curva padrão de glicose.

\section{1 .4 - Determinação da fibra dietăria}

A fibra dietária total, no feijão ou nas suas frações protéicas, foi determinada por via enzimática, de acordo com o mëtodo descrito por Asp et al. (1983). As anâlises dife riram do método descrito, apenas quanto ao agente de filtração, sendo a Celite substituida por lã de vidro.

\section{1 .5 - Extração e fracionamento das proteỉnas}

- Extração aquosa

As albuminas foram extraidas de uma suspensão de $20 \mathrm{~g}$ de farinha de feijão integral em 100ml de água destilada, por agitação, durante 1 hora à $4^{\circ} \mathrm{C}$. Esta suspensão foi filtrada em gaze, centrifugada a $30.000 \mathrm{~g} / 30 \mathrm{~min}$ e o sobrenadante dialisa do contra água destil:ảa por 48 horas e novamente contra água destilada e desmineralizada por mais 24 horas a temperatura de 0-4 ${ }^{\circ} \mathrm{C}$. Esta segunda diálise teve por finalidade promover a precipitação de globulinas que se solubilizaram pela presença de sais naturalmente existentes na semente do feijão. As so- 
Iuções foram concentradas então em evaporador rotatório até a metade do seu volume inicial, liofilizadas e guardadas em congelador atè o uso.

- Extração dás globulinas

As globulinas foram extraỉas e isoladas seguindo ba sicamente o mētodo descrito por McLeester et al. (1973). Uma suspensão de $20 \mathrm{~g}$ de farinha de feijão integral em $100 \mathrm{ml}$ de $\mathrm{NaCl}$ $0,5 \mathrm{M}$ contendo äcido ascörbico $0,25 \mathrm{M} ; \mathrm{pH} 2,2$ foi extraỉda durante 1 hora à temperatura ambiente, filtrada em gaze e centrifugada a $23.000 \mathrm{~g} / 30 \mathrm{~min}$. O sobrenadante constituiu uma prepara ção bruta das globulinas. A partir deste extrato foi obtida a fração globulina Gl pela redução da força iônica do meio. A diluição do extrato com 5 vezes o seu volume de água destilada e deionizada, reduz a força iônica inicial de 0,5M para 0,08M, condição em que ocorre a precipitação da fração Gl (Sun \& Hall, 1975). Este precipitado foi coletado por centrifugação a $23.000 \mathrm{~g} / 30 \mathrm{~min}$ a $4^{\circ} \mathrm{C}$.

- Extração das glutelinas

A fração glutelina foi obtida a partir do residuo da extração das globulinas tendo-se utilizado para esta finalidade um feijão previamente descascado. $100 \mathrm{~g}$ do residuo, seco em estufa ventilada a $45^{\circ} \mathrm{C}$, foram suspensos em $500 \mathrm{ml}$ de $\mathrm{NaOH}$ 
$0,1 \mathrm{~N}$ e extraidas durante 1 hora à temperatura ambiente sob agi tação; o extrato foì centrifugado a $23.000 \mathrm{~g} / 30 \mathrm{~min}$, o resíduo reextraido e os sobrenadantes combinados, constituiram a fração glutelina. Esta solução foi ainda neutralizada e dializada, ocorrendo então a precipitação das glutelinas que: foram recolhidas por centrifugação $(30.000 \mathrm{~g} / 30 \mathrm{~min})$.

As três frações protēicas, albuminas, globulina Gl e glutelinas foram liofilizadas 'e congeladas atẻ o uso.

\section{1 .6 - Determinação do enxofre total}

Um sistema automático de injeção de reagentes em flū xos alternados, desenvolvido e descrito por Krug et al. (1983) foi empregado para a determinação turbidimētrica do sulfato. Tó das as amostras (fontes protēicas, raçōes e fezes) foram digeridas como descrito em 6.3.2). As soluções resultantes foram injetadas e misturadas com cloreto de bärio, para formar a sus pensão de sulfato de bārio, cuja medida turbidimétrica foi efe tuada em espectrofotômetro Varian G34, com unidade de alta sensibilidade REA-112, em comprimento de onda de 4l0nm.

\section{2 - Bioquimicos}

\section{2 .1 - Atividade do inibidor de tripsina}

Empregamos o mëtodo descrito por Kakade et al. (1974), 
medindo-se a redução da velocidade de ação da tripsina bovina sobre o BAPA, na presença do inibidor de tripsina.

\subsection{2 - Atividade inibidora da alfa-amilase}

Foi determinada, usando-se o mêtodo originalmente des crito por Bernfeld, adaptado por Lajolo \& Finardi Filho (1984).

\subsection{3 - Atividade hemaglutinante}

A dosagem da atividade hemaglutinante foi efetuada es sencialmente como descrito por Liener (1955) sendo a leitura fi nal feita atravēs de detecção visual da aglutinação apōs diluição seriada do extrato.

\section{3 - Isotópicos}

6.3 .1 - Determinação do enriquecimento com ${ }^{15} \mathrm{~N}$

A abundância relativa do isōtopo de massa ${ }^{15} \mathrm{~N}$ foi determinada por espectrometria de massa. Para tal, o nitrogênio presente nas amostras foi oxidado a nitrogênio molecular, de acordo com o mētodo de Dumas, modificado para a determinação do nitrogênio-15 (Proksch, 1969; Trivelin et al., 1973). 
intensidade das correntes iônicas correspondentes a massa 28 $\left({ }^{14} \mathrm{~N}-{ }^{14} \mathrm{~N}\right)$ e massa $29\left({ }^{14} \mathrm{~N}-{ }^{15} \mathrm{~N}\right)$. A relação entre essas cor rentes foi convertida em átomos zo do isótopo.

A concentração expressa em ātomo ơ de ${ }^{15} \mathrm{~N}$ em excesso foi obtida, subtraindo-se a abundância natural do ${ }^{15} \mathrm{~N}(0,365 \%)$ dos valores calculados de átomos ò de ${ }^{15} \mathrm{~N}$.

6.3 .2 - Determinação da radioatividade do ${ }^{35} \mathrm{~S}$

A contagem da atividade do ${ }^{35} \mathrm{~S}$ foi determinada após a äigestão de $350 \mathrm{mg}$ das amostras (fontes protéicas, dietas pre paradas e fezes) com ácido nitrico e perclórico, em bloco digestor Tecnal, de acordo com a tëcnica descrita por Krug et al. (1977). As soluções limpidas, resultantes da digestão, foram diluídas com água destilada e deionizada para um volume final de $35 \mathrm{ml}$. Amostras com um peso inferior a $350 \mathrm{mg}$ foram digeridas e diluidas com volumes proporcionais.

As contagens da radioatividade foram efetuadas no

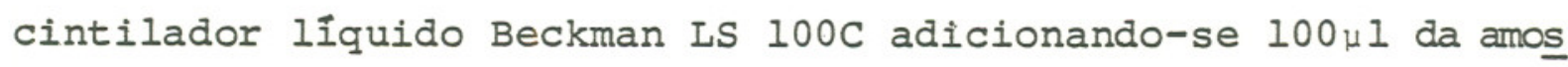
tra a 10ml da solução cintiladora, segundo Bray (1960). As amostras foram contadas por um tempo suficiente para se obter um erro estatistico inferior a $2 \%$. Foi preparada uma curva de padrões com radioatividade conhecida, e, para se obter uma correção do "quenching" adicionou-se a esses padrões amostras das fontes protēicas, dietas e fezes não marcadas, igualmente dige ridas e diluidas medindo-se a redução na contagem dos padrões. 
A eficiência do contador $(0,45)$ foi determinada comparativamen te com outro de eficiência conhecida.

Os resultados foram expressos em dpm (desintegrações por minuto), calculados a partir das contagens por minuto e da eficiência de contador.

$$
\text { dpm }=\frac{c p m}{\text { eficiência do contador }}
$$

\section{4 - Biológicos: ensaios em animais}

6.4.1 - 1a. Experiência: Utilização biolögica das frações protēicas isoladas do feijão (albumi nas, globulina Gl e glutelinas)

o ensaio de 7 dias de duração foi realizado, para avaliar a digestibilidade e o aproveitamento biológico das fra ções protēicas isoladas (albuminas, globulina Gl, glutelinas) e comparando-se os resultados com os indices obtidos a partir de uma ração controle de caseina, contendo o mesmo teor protéico (10\%). Todas as frações protēicas do feijão foram autoclavadas durante $30 \mathrm{~min}$ a $121^{\circ} \mathrm{C}$, liofilizadas e incorporadas nas rações. Os animais (6 ratos Wistar, machos por grupo; peso médio inicial $=38,5 \mathrm{~g}$ ) foram alojados em gaiolas metabólicas individuais. A coleta de fezes foi ini ciada 24 horas após a administração das rações, feita em inter valos de 24 horas e terminada 1 dia após a última ingestão de 
ração. As fezes foram secas em estufa ventilada a $90^{\circ} \mathrm{C}$, e os resíduos de ração removidos, passando-se rapidamente um jato de água corrente pelas fezes que se encontravam numa peneira. A seguir as fezes foram secas novamente, a $90^{\circ} \mathrm{C}$, até peso cons tante, moỉdas e guardadas em geladeira para as determinações ana líticas. Um grupo de animais sob dieta aprotēica foi mantido paralelamente.

A digestibilidade dảs proteinas foi expressa de duas formas :

- Coeficiente de digestibilidade "aparente":

C.D. "aparente" $=\frac{\mathrm{N} \text { absorvido }}{\mathrm{N} \text { ingerido }} \times 100$

- Coeficiente, de digestibilidade "real":

C.D. "real" = $\mathrm{N}$ ingerido $-\frac{(\mathrm{N} \text { fecal }-\mathrm{N} \text { fecal aprotéico })}{\mathrm{N} \text { ingerido }} \times 100$

- O NPR (net protein ratio) (ou razão protēica líquida) foi calculado pela relação:

$N L R=\frac{G \cdot P \cdot \text { teste }+P \cdot P \cdot \text { aprotéico }}{\text { P.I. }}$

G.P.teste - ganho de peso dos animais alimentados com a ração contendo a proteina em estụ do. 


$$
\begin{aligned}
& \begin{aligned}
\text { P.P.aprotéico - } & \text { perda de peso dos animais ali- } \\
& \text { mentados com a ração aprotéica. }
\end{aligned} \\
& \text { P.I. - proteîna em estudo, ingerida. }
\end{aligned}
$$

\subsection{2 - 2a. Experiência: Aproveitamento nutricional do feijão integral, e do feijão adicionado da fração al̈̈uminica}

Examinou-se nessa experiência o efeito da suplementa ção do feijão integral com a albumina isolada, ao nivel : de 10\% da albumina em relação a proteina do feijão integral, num ensaio biológico com ratos. Os feijões e a fração albumina fo ram autoclavados conjuntamente e preparadas as rações experi mentais e controle, de forma semelhante ao experimento anterior, contendo um teor protéico de 10\%. Os animais (6 ratos machos Wistar por grupo, peso médio inicial $=44 \mathrm{~g}$ ) foram alojados individualmente em gaiolas metabólicas e receberam as duas rações experimentais e a ração controle "ad libitum". Paralelamente foi mantido um grupo de animais sob ração aprotéica. o controle de ganho de peso, consumo de ração e excreção fecal foi feito durante 13 dias. 
6.4 .3 - 3a. Experiência: Ensaio das rações marcadas isotopicamente. Efeito do feijão e de suas proteinas isoladas na perda de nitrogênio e enxofre fecais.

A partir dos feijões não marcados ou marcados cam ${ }^{15} \mathrm{~N}$ $e^{35} \mathrm{~s}$ foram obtidas as frações protéicas (albuminas e globulina Gl) pela técnica já descrita anteriormente, e preparadas as rações para ratos, da forma descrita para os dois ensaios anteriores.

A fração glutelina, apesar de merecer mais estudos, não foi incluĩa, em virtude da preemência de tempo para 0 iso lamento das proteinas e o seu ensaio em animais, uma vez que a meia-vida do enxofre radioativo é reduzida (87 dias).

Para uma melhor compreensão dos dados relativos ao conteúdo de nitrogêenio e enxofre, e à marcação isotópica, apre sentamos nas Tabelas 1 a 4 os teores de nitrogênio, nitrogênio-15, enxofre e enxofre-35, tanto para as três fontes protéi cas (feijão integral, albuminas e globulina Gl) bem como das rações preparadas.

Adotou-se $\circ$ seguinte esquema experimental para 0 ensaio com ratas da linhagem Wistar, com peso mëdio inicial de $42 \mathrm{~g}$.

Seis animais em cada grupo (controle e experimentais) receberam durante três dias as rações não marcadas. Apōs este período de adaptação, o número de animais foi reduzido para quatro, que então passaram a receber do 19 ao 69 dia as rações 
TABELA 1 - Teor de nitrogênio total $\left({ }^{14} \mathrm{~N}+{ }^{15} \mathrm{~N}\right)$, nas fontes protéicas e nas rações experimentais.

\begin{tabular}{|c|c|c|c|c|}
\hline \multirow{2}{*}{$\begin{array}{c}\text { Fonte } \\
\text { Protéica }\end{array}$} & \multicolumn{4}{|c|}{8} \\
\hline & $\begin{array}{l}\text { Nitrogênio } \\
\text { na fonte } \\
\text { protēica }\end{array}$ & $\begin{array}{l}\text { Fonte pró } \\
\text { tëica na } \\
\text { ração }\end{array}$ & $\begin{array}{c}\text { Nitrogênio } \\
\text { na } \\
\text { ração }\end{array}$ & $\begin{array}{l}\text { Proteína } \\
\text { na ração } \\
(\mathrm{N} \times 5,7)\end{array}$ \\
\hline & $\cdot$ & & & \\
\hline \multirow[t]{2}{*}{ Feijão integral } & $4,29 *$ & 40,89 & 1,77 & 10,08 \\
\hline & $4,12 * *$ & 42,57 & 1,64 & 9,35 \\
\hline \multirow[t]{2}{*}{ Albuminas } & $11,46 *$ & 15,32 & 1,75 & 9,98 \\
\hline & $11,31 * *$ & 15,52 & 1,60 & 9,13 \\
\hline \multirow[t]{2}{*}{ Globulina Gl } & $15,38 *$ & 11,42 & 1,57 & 8,94 \\
\hline & $16,92 * *$ & 10,94 & 1,54 & 8,80 \\
\hline $\begin{array}{l}\text { Caseina + } \\
1 \% \text { DL-metionina }\end{array}$ & $12,34 *$ & 12,34 & 1,60 & $9,98 * *$ \\
\hline
\end{tabular}

Os valores analíticos representam a média de 3 determinações

* fonte protéica não marcada isotopicai.ente

** fonte protéica marcada com ${ }^{15} \mathrm{~N}$ e ${ }^{35} \mathrm{~S}$

*** fator de conversão do $\mathrm{N}=6,25$ 
TABELA 2 - Teor de ${ }^{15} \mathrm{~N}$ nas fontes protêicas e nas rações experimentais.

\begin{tabular}{|c|c|c|c|c|c|}
\hline \multirow{3}{*}{ Fonte Protéica } & \multicolumn{2}{|c|}{$\begin{array}{c}\text { Atomos \& de }{ }^{15} \mathrm{~N} \\
\text { em excesso* }\end{array}$} & \multirow{3}{*}{$\begin{array}{l}8 \text { de } \mathrm{N} \\
\text { total } \\
\text { na ração }\end{array}$} & \multicolumn{2}{|c|}{$\begin{array}{c}\mathrm{mg} \text { de }{ }^{15} \mathrm{~N} \text { em excesso/ } \\
/ 100 \mathrm{~g} \text { de ração }\end{array}$} \\
\hline & Resultado & Analitico & & Calculado a & Calculado a \\
\hline & $\begin{array}{l}\text { Fonte } \\
\text { Protēica }\end{array}$ & Ração & & $\begin{array}{l}\text { partir do } \\
{ }^{15} \mathrm{~N} \text { da fon } \\
\text { te protéica }\end{array}$ & $\begin{array}{l}\text { partir do } \\
15 \mathrm{~N} \text { da ra- } \\
\text { ção }\end{array}$ \\
\hline Feijão integral* & 0,526 & 0,493 & 1,641 & 8,63 & 8,09 \\
\hline Albuminas & 1,124 & 1,076 & 1,602 & 18,01 & 17,24 \\
\hline Globulina Gl * & 0,480 & 0,498 & 1,544 & 7,41 & 7,69 \\
\hline
\end{tabular}

Os valores analíticos representam a média de duas ou três determinações.

* abundância natural de ${ }^{15} \mathrm{~N}=0,365$ átomos \& de ${ }^{15} \mathrm{~N}$.

** após diluição com $50 \%$ de fonte protéica não marcadá. 
TABELA 3 - Teor de enxofre total nas fontes protéicas e nas ra ções experimentais.

\begin{tabular}{|c|c|c|c|c|}
\hline & $\%$ enxofre & \% fon- & enxofre & na ração \\
\hline Fonte Protéica & $\begin{array}{l}\text { na fonte } \\
\text { protéica* }\end{array}$ & $\begin{array}{l}\text { te protēi } \\
\text { ca na ração }\end{array}$ & Calculado* & Analítico \\
\hline Feijão integral & $0,238 \pm 0,007$ & 42,57 & 0,148 & $0,167 \pm 0,006$ \\
\hline Albuminas & $0,511 \pm 0,010$ & 15,52 & 0,126 & $0,137 \pm 0,006$ \\
\hline Globulina Gl & $0,240 \pm 0,000$ & 10,94 & 0,069 & $0,087 \pm 0,005$ \\
\hline
\end{tabular}

Os valores analíticos representam a média de 3 determinações 士 desvio padrão.

* calculado a partir da o de enxofre na fonte protéica + $\frac{q}{8}$ enxo fre na ração aprotēica $(0,047)$.

TABELA 4 - Atividade do ${ }^{35} \mathrm{~S}$ nas fontes protēicas e nas rações experimentais.

\begin{tabular}{|c|c|c|c|c|}
\hline \multirow{2}{*}{$\begin{array}{l}\text { Fonte } \\
\text { Protēica }\end{array}$} & \multirow{2}{*}{$\begin{array}{l}\text { Atividade } \\
\text { na fonte } \\
\text { protēica } \\
\text { dpm.10-4/g }\end{array}$} & \multirow{2}{*}{$\begin{array}{l}\text { o Fonte } \\
\text { protéica } \\
\text { na ração }\end{array}$} & \multicolumn{2}{|c|}{$\begin{array}{l}\text { Atividade na ração } \\
\text { dpm } \cdot 10^{-5} / 100 \mathrm{~g}\end{array}$} \\
\hline & & & Calculado & Analítico \\
\hline $\begin{array}{l}\text { Feijão } \\
\text { integral* }\end{array}$ & 11,2 & 42,57 & 47,7 & 49,1 \\
\hline Albumina & 44,4 & 15,52 & 68,9 & 71,4 \\
\hline Globulina Gl* & 10,7 & 10,94 & 11,7 & 11,73 \\
\hline
\end{tabular}

Os valores analíticos representam a mëdia de 3 determinações. *após diluição com $50 \%$ de fonte protéica não marcada. 
com proteina marcada, sendo que no lo dia os animais receberam a ração por um periodo de 12 horas. Do 7\% ao 11 : dia os ratos voltaram a receber as rações não marcadas.

A ägua e o alimento foram oferecidos "ad libitum" e os animais mantidos em gaiolas metabölicas individuais. A coleta de fezes e urina foi iniciada 12 horas após a administração das rações marcadas e daĩ por diante, em intervalos de 24 horas, sendo terminada 24 horäs após a última ingestão da ração. As fezes foram secas e tratadas como jā descrito. o con sumo de ração foi anotado diariamente durante todo o experimen to.

\section{5 - Estatisticos}

Os resultados obtidos através dos ensaios biológi cos foram submetidos à análise de variância. Em virtude das diferenças significativas encontradas, prosseguiu-se a análise de variância atravēs das Comparações Múltiplas de Tukey (Nê ter et al., 1985). 
Inicialmente apresentamos os resultados das experiências, compreendendo a extração e purificação das proteínas do feijão (Phaseolus vulgaris, L.), enriquecidas ou não isotopicamente com ${ }^{15} \mathrm{~N}$ e ${ }^{35} \mathrm{~s}$, seguidos dos resultados dos ensaios biológicos.

Esses ensaios, foram realizados primeiramente com as frações protēicas isoladas e aquecidas, porēm não marcadas, na tentativa de identificar a fração ou frações responsáveis pela reduzida utilização biológica do feijão. Demos sequência ao es tudo através de um ensaio biológico dos feijões e de suas pro teinas marcadas, com a finalidade de se obter resultados que pudessem explicar o comportamento observado em trabalhos anteriores (Lanfer Marquez \& Lajolo, 1981).

7.1 - Extração e fracionamento das proteinas do feijão

Com a metodologia adotada (descrita no item 6.1.5) foi possivel obter as frações protēicas, atravēs de extrações suces sivas de pequenos lotes de feijão. 
A fração globulina Gl isolada, representando aproximadamente $50 \%$ das proteinas totais do feijão, mostrou em média após a sua liofiização, um teor de nitrogênio da ordem de $16 \%$, que convertido, forneceu uma concentração de proteína em torno de $90 \%$. O teor de carboidratos nesta fração foi aproximadamen te de $12 \%$.

A fração albuminica liofilizada, continha em média $11,4 \%$ de nitrogênio (65\% proteîna). Concentrações de nitrogênio superiores a esse valor foram observadas algumas vezes e re lacionadas com uma maior contaminação cruzada pela globulina G2, solúvel mesmo em concentrações salinas muito reduzidas.

A fração albuminica obtida dessa forma, representa 16,5\% da proteína total do feijão e está acompanhada de um elevado teor de carboidratos ( $30 \mathrm{mg} / 100 \mathrm{mg}$ proteina).

A precipitação das proteinas dessa fração com ãcido tricloroacético (ćoncentração final 5\%) mostrou que $1 / 3$ desses carboidratos foram recuperados no precipitado, evidenciando pos suir glicoproteínas ou açúcares ligados a outras macromolécu las ou ainda conter polissacarideos de alto peso molecular.

A fração glutelina foi obtida a partir de feijão pre viamente descascado. Este procedimento tornou-se necessärio, pois uma grande quantidade de pigmentos da casca seriam extraidos concomitaiicemente. Esta fração protéica constitui uma preparação bastante impura, com 10,4\% de nitrogênio, necessitando no futuro uma caracterização química mais completa. 


\section{2 - Enriquecimento isotópico das proteinas do feijão}

As sementes de feijão, marcadas com os isótopos duran te o seu desenvolvimento, apresentaram um enriquecimento satisfatório, com uma concentração de 1,052 ätomos $\%$ de ${ }^{15} \mathrm{~N}$ em exces so. As frações protēicas isoladas a partir desse feijão (albuminas e globulina Gl), apresentaram um teor de 1,124 e 0,960 ató mos $\%$ de ${ }^{15} \mathrm{~N}$ em excesso, respectivamente, mostrando que esse isōtopo está distribuỉo de uma forma relativamente homogênea entre as proteinas do feijão.

A metabolização do sulfato marcado pela planta inteira resultou numa atividade radioativa de $22,3 \cdot 10^{-4} ; 44,4 \cdot 10^{-4}$ e $21,4 \cdot 10^{-4} \mathrm{dpm} / \mathrm{g}$ de feijão integral, fração albuminica e glo bulina Gl, respectivamente.

Determinou-se tambēm o teor de enxofre total nas mesmas frações protēícas, tendo-se observado uma correlação entre a concentração total de enxofre e a atividade do enxofre-35. A relação ${ }^{35} \mathrm{~S} / \mathrm{s}$ manteve-se constante para as três fontes protéi cas.

Os valores numëricos relativos ao conteúdo de nitrogê nio e enxofre totais e ao ${ }^{15} \mathrm{~N}$ e ${ }^{35} \mathrm{~s}$ no feijão integral, nas fra ções protéicas e nas rações preparadas são apresentadas nas Tabelas 1 a 4 . 


\section{3 - Ensaios em animais}

\subsection{1 - Digestibilidade e valor nutricional}

Os resultados de dois ensaios biológicos, visando verificar o efeito da ingestão do feijão cozido ou de suas proteinas isoladas sobre o crescimento e aproveitamento alimentar, estão apresentados nas Tabelas 5 e 6 e na Figura 1.

Observamos uma elevada digestibilidade "real" para a albumina $(92,5 \%)$ e globulina Gl $(90,8 \%)$, sendo apenas a digesti tibilidade da fração glutelinica $(78,7 \%)$ significativamente inferior à da caseina $(95,2 \%)$.

Independentemente da digestibilidade, as glutelinas e albuminas promoveram $\circ$ melhor crescimento dos animais embora este tenha sido baixo em comparação ao controle de caseina. O NPR ("net protein utilization" ou razão protéica líquida) calculado (mesmo para um experimento de apenas sete dias) foi muito reduzido para a globulina $\mathrm{Gl}(2,20)$ e para as albuminas e glutelinas foi $30 \%$ inferior ao controle de caseina $(4,26)$.

Este ensaio procurou evidenciar os efeitos da ingestão do feijão integral sobre os indices de digestibilidade e vạ lor nutricional, comparando-os com os efeitos causadus, pela ingestão das frações protēicas isoladas. Foi incluido tambēm, um grupo de animais que recebeu uma farinha de feijão suplementada com a fração albuminica. 
TABELA 5 - Experiência 1 - Digestibilidade e "NPR" das proteínas isoladas do feijão (Ensaio de 7 dias de duração) *

\begin{tabular}{|c|c|c|c|c|c|c|c|c|}
\hline \multirow{2}{*}{$\begin{array}{c}\text { Fonte } \\
\text { Protêica }\end{array}$} & \multirow{2}{*}{$\begin{array}{l}\text { Ganho de } \\
\text { peso (g) }\end{array}$} & \multirow{2}{*}{$\begin{array}{l}\text { Proteina } \\
\text { ingerida } \\
\text { (g) }\end{array}$} & \multirow{2}{*}{ NPR } & \multicolumn{2}{|c|}{ Nitrogēnio $(\mathrm{g})$} & \multicolumn{2}{|c|}{ Digestibilidade $\left(\frac{8}{)}\right)$} & \multirow{2}{*}{$\begin{array}{l}\text { Matērita } \\
\text { seca fecal } \\
\text { mg/g ração }\end{array}$} \\
\hline & & & & ingerido & fecal & "aparente" & "real" & \\
\hline Caseĩna & $17,9 \pm 3,9$ & $5,44 \pm 0,44$ & $4,26 \pm 0,60^{\mathrm{a}}$ & $0,87 \pm 0,07$ & $0,08 \pm 0,02$ & $90,0 \pm 2,6$ & $95,2 \pm 1,7^{\mathrm{a}}$ & $34,0 \pm 5,0^{a}$ \\
\hline Albuminas & $3,8 \pm 0,7$ & $3,03 \pm 0,03$ & $3,00 \pm 0 ; 19^{\mathrm{bc}}$ & $0,53 \pm 0,00$ & $0,08 \pm 0,01$ & $84,6 \pm 1,2$ & $92,5^{+}-2,3^{\text {ac }}$ & $46,8^{+} 2,4^{\text {ad }}$ \\
\hline Globulina Gl & $1,3 \pm 2,3$ & $2,96 \pm 0,46$ & $2,20 \pm 0,48 \mathrm{bde}$ & $0,52+0,08$ & $0,08-^{+} 0,02$ & $84,1 \pm 4,8$ & $90,8 \pm 4,3^{\text {ace }}$ & $54,6^{+} 14,6$ bdf \\
\hline Glutelinas & $7,0 \pm 1,6$ & $3,94 \pm 0,28$ & $2,91 \pm 0,63^{\text {bce }}$ & $0,69 \pm 0,05$ & $0,18 \pm 0,03$ & $73,2 \pm 3,4$ & $78,7 \pm 3,5$ bdf & $68,4-11,1^{\text {cef }}$ \\
\hline
\end{tabular}

*Valores médios \pm desvio padrão de 4 ou 6 animais (caseína) por grupo.

Perda de peso de animais sob dieta aprotēica: 5,3g/rato/7 dias

Nitrogênio fecal dos animais sob dieta aprotéica: 5,28mg N/rato/dia

$a, b, c, \ldots$ Valores nas mesmas colunas verticais, com letras diferentes, diferem estatís ticamente $(p \leqslant 0,05)$. 
TABELA 6 - Experiência 2 - Digestibilidade e "NPR" do feijão ou feijão suplementado com a fra ção albumina (Ensaio de 13 dias de duração).

\begin{tabular}{|c|c|c|c|c|c|c|c|c|}
\hline \multirow{3}{*}{$\begin{array}{c}\text { Fonte } \\
\text { Protēica }\end{array}$} & \multicolumn{3}{|c|}{13 dias } & \multicolumn{5}{|c|}{7 ūltimos dias } \\
\hline & \multirow{2}{*}{$\begin{array}{l}\text { Ganho de } \\
\text { peso } \\
\text { (g) }\end{array}$} & \multirow{2}{*}{$\begin{array}{l}\text { Proteina } \\
\text { ingerida } \\
\text { (g) }\end{array}$} & \multirow[b]{2}{*}{ NPR } & \multicolumn{2}{|c|}{ Nitrogênio (g) } & \multicolumn{2}{|c|}{ Digestibilidade (₹) } & \multirow{2}{*}{$\begin{array}{l}\text { Matēria } \\
\text { seca } \\
\text { fecal } \\
\text { mg/g ração }\end{array}$} \\
\hline & & & & ingerido & fecal & "aparente" & "real" & \\
\hline Caseỉna & $44,2^{ \pm}-6,8^{\mathrm{a}}$ & $12,82 \pm_{1}, 20$ & $4,12 \pm 0,27^{\mathrm{a}}$ & $1,01 \pm 0,06$ & $0,07 \pm 0,01$ & $93,1 \pm 0,7$ & $96,1 \pm 0,6^{a}$ & $33,9 \pm 3,0^{\mathrm{a}}$ \\
\hline $\begin{array}{l}\text { Feijão } \\
\text { integral }\end{array}$ & $14,4-1,6^{\mathrm{bd}}$ & $9,56 \pm 0,85$ & $2,43 \pm 0,32^{\mathrm{bd}}$ & $0,77 \pm 0,05$ & $0,26 \pm 0,04$ & $66,0 \div 5,7$ & $69,9 \pm 5,7^{\mathrm{bd}}$ & $145,5-22,0 \mathrm{bd}$ \\
\hline $\begin{array}{l}\text { Feijão } \\
\text { integral + } \\
\text { albumina }\end{array}$ & $18,5^{ \pm}-1,9^{\mathrm{cd}}$ & $10,17 \pm 0,33$ & $2,68^{ \pm}-0,26^{\mathrm{cd}}$ & $0,91 \pm 0,09$ & $0,30 \pm 0,02$ & $66,7 \pm_{1,6}$ & $69,9 \pm 1,3^{\mathrm{cd}}$ & $128,8^{ \pm} 8,7^{\mathrm{od}}$ \\
\hline
\end{tabular}

*Valores médios \pm desvio padrão de 6 animais por grupo.

Perda de peso dos animais sob dieta aprotêica: 8,7g/rato/13 dias.

Nitrogênio fecal dos animais sob dieta aprotēica: 4,28mg N/rato/dia.

a, b, c, d - Valores nas mesmas colunas verticais, com letras diferentes, diferem estatísticamente $(p \leqslant 0,05)$. 


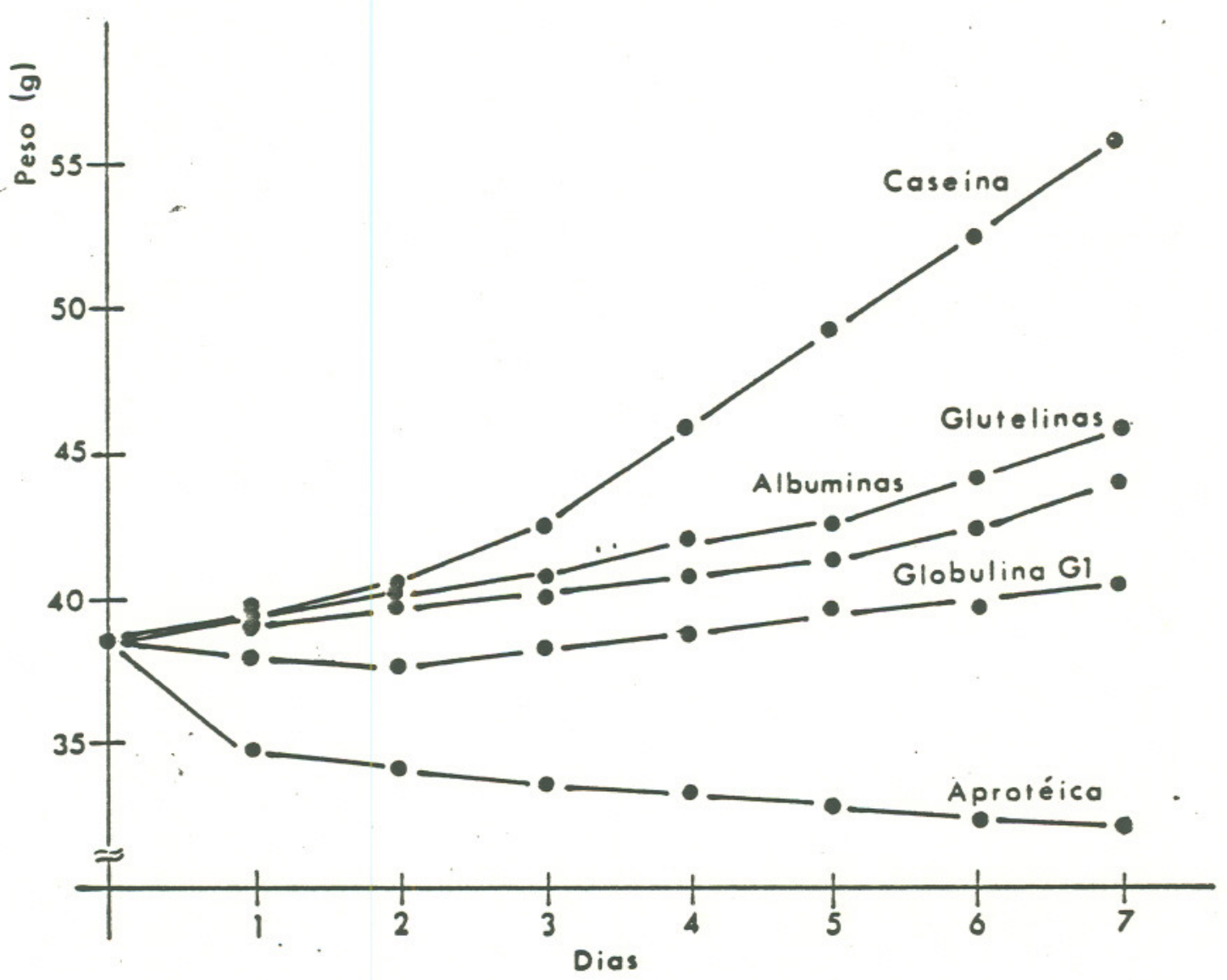

FIGURA 1 - Curvas de peso de ratos, alimentadós com rações de caseina e proteinas do feijão (10\% de proteina).

Ainda, na Tabela 5 são mostrados os resultados refe rentes às quantidades de proteina e nitrogênio ingeridos, bem como à excreção fecal de matēria seca, calculada em função da quantidade de ração consumida.

Os grupos de animais que receberam as rações à base de caseina, albuminas, globulina Gl e glutelinas excretaram res pectivamente 34,$0 ; 46,8 ; 54,6$ e $68,4 \mathrm{mg}$ de matëria fecal seca/g ração ingerida. As comparações estatisticas mostram que apesar de todas as frações protéicas parecerem estimular uma maior ex- 
creção fecal, apenas a da albumina foi estatisticamente seme lhante à da caseína.

Na Tabela 6 são apresentados os resúltados de um experimento, no qual grupos de seis ratos, foram alimentados com ração cujo teor protēico (10\%) foi fornecido por caseina, farinha de feijão integral ou farinha de feijão suplementada com a fração albuminica ao nível de $10 \%$ em relação a proteina (tanto a farinha intëgral como a farinha já suplemen tada foram aquecidas durante 30 minutos a $121^{\circ} \mathrm{C}$, para a inativa ção dos fatores antinutricionais).

\subsection{2 - Ensaio biolögico do feijão integral, albumi - nas e globulina Gl, marcados isotopicamente}

Essa experiência foi realizada de acordo com o esquema experimental descrito no item 6.4.3.

Basicamente dividiu-se 0 ensaio em três fases: numa primeira fase de adaptação, os animais receberam durante 3 dias as dietas não marcadas, contendo $10 \%$ de proteina proveniente do feijão integral, albuminas, globulina Gl ou caseina.

$\mathrm{Na} 2 \mathrm{a}$. fase, os animais foram alimentados durante 6 dias com raç̃̃es preparadas de forma semelhante à anterior, com a única diferença das fontes protéicas estarem marcadas isotopi camente.

Numa 3a. fase "de decaimento" de 6 dias de duração os animais voltaram a receber as rações "frias". 
Paralelamente à determinação diāria das concentrações isotōpicas das raçōes ingeridas e do material fecal eliminado, avaliamos a "digestibilidade" e a "utilização biológica" pela metodologia convencional (de anālise química), reunindo esses re sultados como comparação e confirmação daqueles já descritos.

As variações de peso, e a utilização biológica das proteinas, apresentadas pelos animais submetidos às diferentes rações, são mostradas na Tabelia 7 .

Durante os 12 dias da experiência, apenas os animais que receberam ração à base de albuminas, tiveram um crescimento mensurável, um "NPR" de $71 \%$ e digestibilidade de $90 \%$ em relação à caseỉna considerada $100 \%$.

A globulina Gl, apesar de sua boa digestibilidade, não proporcionou nenhum crescimento aos animais. No grupo de animais alimentados com ração à base de feijão integral, observou-se reduzido Indiće de digestibilidade (67\%), ganho de peso e "NPR", acompanhado de uma elevada excreção de nitrogênio, três vezes superior à da caseina.

\section{3 .3 - Efeito do feijão integral, da fração albumina e da globulina Gl na perda de nitrogênio}

Estudaram-se aqui, separadamente, cada uma das frações protéicas (albuminas e globulina Gl) como tambēm o feijão integral, determinando-se o balanço diärio entre o nitrogênio total $e^{15} \mathrm{~N}$, ingeridos e excretados nas fezes durante os doze dias da experiência. 
TABELA 7 - Experiência 3 - Digestibilidade e "NPR" do feijão integral e de suas proteínas isoladas. (Ensaio de 12 dias de duração)*.

\begin{tabular}{|c|c|c|c|c|c|c|c|c|}
\hline $\begin{array}{l}\text { Fonte } \\
\text { Protéica }\end{array}$ & $\begin{array}{l}\text { Ganho de } \\
\text { peso } \\
(\mathrm{g})\end{array}$ & $\begin{array}{l}\text { Proteỉna } \\
\text { ingerida } \\
\text { (g) }\end{array}$ & NPR & ingerido & fecal & "aparente" & "real" & $\begin{array}{l}\text { 'Matēria se } \\
\text { ca fecã } \\
\text { mg/g ração }\end{array}$ \\
\hline
\end{tabular}

\begin{tabular}{|c|c|c|c|c|c|c|c|c|}
\hline Caseîna & $36,3 \pm 7,8$ & $10,05 \pm 1,81$ & $4,46 \pm 0,10^{\mathrm{a}}$ & $1,61 \pm 0,29$ & $0,18 \pm 0,04$ & $89,0 \pm 0,7$ & $91,8 \pm 1,1^{a}$ & $41,3 \pm 1,0^{\mathrm{a}}$ \\
\hline $\begin{array}{l}\text { Feijão } \\
\text { integral }\end{array}$ & $4,8 \pm 1,7$ & $5,85 \pm 0,59$ & $2,27 \pm 0,29^{\mathrm{be}}$ & $1,03 \pm 0,10$ & $0,38 \pm 0,08$ & $62,8 \pm 6,5$ & $67,2 \pm 6,6^{\mathrm{bd}}$ & $127,9 \pm 19,8 \mathrm{bd}$ \\
\hline Albuminas & $13,7 \pm 1,1$ & $7,02 \pm 0,59$ & $3,18 \pm 0,39^{\mathrm{cfh}}$ & $1,23 \pm 0,10$ & $0,26 \pm 0,03$ & $79,1 \pm 2,1$ & $82,8 \pm 2,0^{\mathrm{ceg}}$ & $68,3 \pm 6,1^{\text {ceg }}$ \\
\hline Globulina Gl & $-2,1 \pm 0,8$ & $4,36 \pm 2,09$ & $1,51 \pm 0,41{ }^{d g i}$ & $0,76 \pm 0,10$ & $0,08 \pm 0,01$ & $89,5 \pm 1,6$ & $95,4 \pm 0,7^{\text {afh }}$ & $37,6 \pm 4,9^{\mathrm{afh}}$ \\
\hline
\end{tabular}

*Valores médios \pm desvio padrão de 4 animais por grupo.

Perda de peso dos animais sob dieta aprotéica: $8,5 \mathrm{~g}$ rato/12 dias.

Nitrogênio fecal dos animais sob dieta aprotéica: 3,77mg N/dia/rato.

$a, b, c, \ldots$ Valores nas mesmas colunas verticais, com letras diferentes, diferem estatisticamente.

$(P \leqslant 0,05)$. 
As Tabelas 8 a 10 mostram, como era de se esperar, que a porcentagem de excreção de nitrogênio total se manteve aproxi madamente constante para cada fonte protéica durante todo $\circ$ experimento. Assim, para o feijão integral, a eliminação de nitrogênio total foi muito elevada, da ordem de $34,4 \%$ em média; $20,4 \%$ para as albuminas e $10,7 \%$ para a globulina Gl.

Quanto à excreção fecal de ${ }^{15} \mathrm{~N}$ observamos, nos primeiro três dias após a administräção da ração marcada, um aumento na excreção desse isótopo, atingindo neste periodo um estado que tomamos como "estacionārio" e no qual a relação entre a quantidade de ${ }^{15} \mathrm{~N}$ ingerido e excretado se manteve praticamente inalte rada, até o sexto dia, quando os animais passaram a receber novamente as rações não marcadas, com o intuito de observar a velocidade de decaimento da concentração do isotópo nas fezes.

A excreção de ${ }^{15} \mathrm{~N}$ na fase de equilíbrio (48-68 dia ) mostrou ser constánte e especifica para cada fonte de proteina, apesar de ser inferior às quantidades médias de nitrogênio total excretadas. Esses resultados serão discutidos mais adiante, sendo possivel, como veremos, aṫribuir esse efeito a diversas cau sas.

\subsection{4 - Efeito do feijão integ::al e das frações pro- tēicas isoladas, na eliminação de enxofre}

Paralelamente às determinações de nitrogênio total e $15_{\mathrm{N}}$ nas rações ingeridas e no material fecal, determinou-se tam 
TABELA 8 - Experiência 3 - Ensaio do feijão integral: Ingestão e excreção fecal diárias nitrogênio total $\left({ }^{14} \mathrm{~N}+{ }^{15} \mathrm{~N}\right)$ e de ${ }^{15} \mathrm{~N}$. *

\begin{tabular}{|c|c|c|c|c|c|c|c|}
\hline \multirow{8}{*}{ 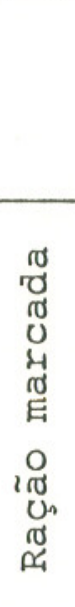 } & \multirow{3}{*}{$\frac{\text { Dia }}{1}$} & \multicolumn{2}{|c|}{$\mathrm{N}$ total (mg)/rato } & \multicolumn{2}{|c|}{${ }^{15} \mathrm{~N}$ (mg ${ }^{15} \mathrm{~N}$ em excesso) /rato } & \multicolumn{2}{|c|}{$\begin{array}{l}\text { \& de excreção em } \\
\text { relação ao ingerido }\end{array}$} \\
\hline & & ingerido & excretado & ingerido & excretado & \multirow{2}{*}{$\frac{N \text { total }}{31,95}$} & \multirow{2}{*}{$\frac{{ }^{15} \mathrm{~N}}{8,67}$} \\
\hline & & $95,02 \pm 9,16$ & $30,36 \pm 7,75$ & $0,45 \pm 0,04$ & $0,039 \pm 0,016$ & & \\
\hline & 2 & $93,31 \pm 10,45$ & $35,22 \pm 4,07$ & $0,44 \pm 0,05$ & $0,104 \pm 0,010$ & 37,74 & 23,64 \\
\hline & 3 & $94,60 \pm 9,38$ & $38,71 \pm 11,20$ & $0,45 \pm 0,04$ & $0,138 \pm 0,035$ & 40,91 & 30,67 \\
\hline & 4 & $95,02 \pm 9,16$ & $35,09 \pm 11,88$ & $0,45 \pm 0,04$ & $0,125 \pm 0,041$ & 36,93 & 27,78 \\
\hline & 5 & $86,93 \pm 15,93$ & $35,45 \pm 11,30$ & $0,41 \pm 0,07$ & $0,134 \pm 0,040$ & 40,78 & 32,68 \\
\hline & 6 & $91,19 \pm 12,48$ & $31,90 \pm 8,69$ & $0,43 \pm 0,06$ & $0,119 \pm 0,035$ & 34,98 & 27,67 \\
\hline \multirow{6}{*}{ 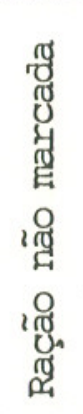 } & 7 & $88,42 \pm 9,44$ & $28,62 \pm 3,19$ & - & $0,080 \pm 0,009$ & 32,37 & - \\
\hline & 8 & $88,63 \pm 10,04$ & $31,18 \pm 9,03$ & - & $0,044 \pm 0,014$ & 35,18 & - \\
\hline & 9 & $93,32 \pm 15,95$ & $27,92 \pm 10,33$ & - & $0,019 \pm 0,006$ & 29,92 & - \\
\hline & 10 & $98,01 \pm 21,76$ & $28,52 \pm 8,97$ & - & $0,01,9 \pm 0,007$ & 29,10 & - \\
\hline & 11 & $102,69 \pm 29,01$ & $31,54 \pm 8,11$ & - & $0,014 \pm 0,004$ & 29,10 & - \\
\hline & 12 & nd & $32,59 \pm 10,15$ & - & $0,013 \pm 0,005$ & nd & - \\
\hline \multicolumn{2}{|c|}{ Média } & & & 0,44 & $0,126 * *$ & 34,4 & 29,37 * * \\
\hline
\end{tabular}

*Valores médios \pm desvio padrão $(n=4)$

Marcação isotópica da ração: 0,493 átomos 8 de ${ }^{15} \mathrm{~N}$ em excesso ** 8 de excreção média de ${ }^{15} \mathrm{~N}$ na fase de "equilíbrio". (48 ao 68 dia) nd $=$ não determinado. 
TABELA 9 - Experiêncła 3 - Ensaio da fração albumininca: Ingestão e excreção fecal diárias de nitrogênio total $\left({ }^{14} \mathrm{~N}+{ }^{15} \mathrm{~N}\right)$ e de ${ }^{15} \mathrm{~N} *$.

\begin{tabular}{|c|c|c|c|c|c|c|c|}
\hline & \multirow{2}{*}{ Dia } & \multicolumn{2}{|c|}{$\mathrm{N}$ total (mg) / rato } & \multicolumn{2}{|c|}{${ }^{15} \mathrm{~N}\left(\mathrm{mg}{ }^{15} \mathrm{~N}\right.$ em excesso) /rato } & \multicolumn{2}{|c|}{$\begin{array}{l}\text { \& de excreção em } \\
\text { relação ao ingerido }\end{array}$} \\
\hline & & ingerido & excretado & ingerido & excretado & $\mathrm{N}$ total & ${ }^{15} \mathrm{~N}$ \\
\hline \multirow{6}{*}{ 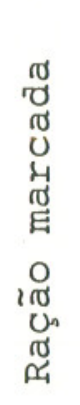 } & 1 & $93,31 \pm 6,72$ & $19,93 \pm 5,11$ & $1,00 \pm 0,07$ & $0,037 \pm 0,017$ & 21,36 & 3,70 \\
\hline & 2 & $93,32 \pm 9,10$ & $24,07 \pm 6,71$ & $1,00 \pm 0,10$ & $0,166 \pm 0,033$ & 25,79 & 16,60 \\
\hline & 3 & $94,12 \pm 9,56$ & $21,34 \pm 5,31$ & $1,01 \pm 0,10$ & $0,158 \pm 0,042$ & 22,67 & 15,64 \\
\hline & 4 & $92,32 \pm 8,00$ & $19,11 \pm 4,43$. & $1,04 \pm 0,08$ & $0,154 \pm 0,034$ & 19,64 & 14,81 \\
\hline & 5 & $113,34 \pm 13,24$ & $20,49 \pm 8,55$ & $1,22 \pm 0,14$ & $0,169 \pm 0,076$ & 18,08 & 13,85 \\
\hline & 6 & $114,95 \pm 12,01$ & $22,68 \pm 2,84$ & $1,23 \pm 0,13$ & $0,193 \pm 0,026$ & 19,73 & 15,69 \\
\hline \multirow{6}{*}{ 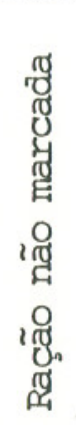 } & 7 & $110,94 \pm 18,61$ & $20,93 \pm 1,01$ & - & $0,146 \pm 0,018$ & 18,87 & - \\
\hline & 8 & $114,14 \pm 15,22$ & $23,70 \pm 4,50$ & - & $0,059 \pm 0,029$ & 20,76 & - \\
\hline & 9 & $114,94 \pm 14,53$ & $22,49 \pm 4,61$ & - & $0,026 \pm 0,002$ & 19,57 & - \\
\hline & 10 & $117,34 \pm 13,17$ & $19,49 \pm 4,17$ & - & $0,019 \pm 0,003$ & 16,61 & - \\
\hline & 11 & $117,34 \pm 8,81$ & $25,21 \pm 6,99$ & - & $0,021 \pm 0,005$ & $21 ; 48$ & - \\
\hline & 12 & nd & $18,06 \pm 4,23$ & - & $0,012 \pm 0,003$ & nd & - \\
\hline \multicolumn{2}{|c|}{ Média } & & & 1,08 & 0,172 ** & 20,41 & 14,78 ** \\
\hline
\end{tabular}

* Valores médios \pm desvio padrão $(n=4)$

Marcação isotópica da ração: 1,076 átomos \& de ${ }^{15} \mathrm{~N}$ em excesso.

** \& de excreção média de ${ }^{15} \mathrm{~N}$ na fase de "equilíbrio" (48 ao 68 dia)

nd = não determinado 
TABELA 10 - Experiência 3 - Ensaio da globulina Gl: Ingestão e excreção fecal diárias de nitrogênio total $\left({ }^{14} \mathrm{~N}+{ }^{15} \mathrm{~N}\right)$ e de ${ }^{15} \mathrm{~N}$. *

\begin{tabular}{|c|c|c|c|c|c|c|c|}
\hline & \multirow{2}{*}{ Dia } & \multicolumn{2}{|c|}{$\mathrm{N}$ total $(\mathrm{mg}) /$ rato } & \multicolumn{2}{|c|}{${ }^{15} \mathrm{~N}\left(\mathrm{mg}{ }^{15} \mathrm{~N}\right.$ em excesso)/rato } & \multicolumn{2}{|c|}{$\begin{array}{c}\text { \& excreção em relação } \\
\text { ao ingerido }\end{array}$} \\
\hline & & ingerido & excretado & ingerido & excretado & $\mathrm{N}$ total & ${ }^{15} \mathrm{~N}$ \\
\hline \multirow{6}{*}{ 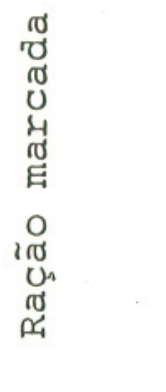 } & 1 & 81,25 & 11,75 & 0,405 & traços & 14,46 & traços \\
\hline & 2 & 77,50 & 8,25 & 0,385 & 0,012 & 10,64 & 3,12 \\
\hline & 3 & 69,75 & 5,25 & 0,345 & 0,010 & 7,53 & 2,90 \\
\hline & 4 & 71,00 & 5,50 & 0,35 & 0,013 & 7,75 & 3,69 \\
\hline & 5 & 118,75 & 6,00 & 0,59 & 0,016 & 5,05 & 2,71 \\
\hline & 6 & 118,75 & 8,00 & 0,59 & 0,025 & 6,74 & 4,24 \\
\hline \multirow{6}{*}{ 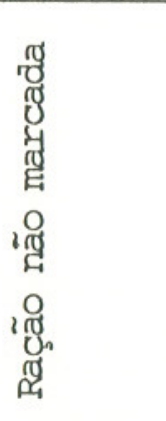 } & 7 & 44,25 & 5,50 & - & 0,014 & 12,43 & - \\
\hline & 8 & 42,00 & 6,00 & - & 0,010 & 14,28 & - \\
\hline & 9 & 44,00 & 5,50 & - & nd. & 12,50 & - \\
\hline & 10 & 44,75 & 7,25 & - & 0,004 & 16,20 & - \\
\hline & 11 & 67,25 & 6,52 & - & 0,003 & 9,69 & - \\
\hline & 12 & nd & 5,52 & - & traços & nd & - \\
\hline Média & & & & , 0,44 & 0,018 ** & 10,66 & $3,54 * *$ \\
\hline
\end{tabular}

*Valores médios de um "pool" de 4 animais

Marcação isotópica da ração: 0,498 átomos \& de ${ }^{15} \mathrm{~N}$ em excesso.

** $\%$ de excreção média de ${ }^{15} \mathrm{~N}$ na fase de "equilíbrio" (48 ao 68 dia)

nd $=$ não determinado. 


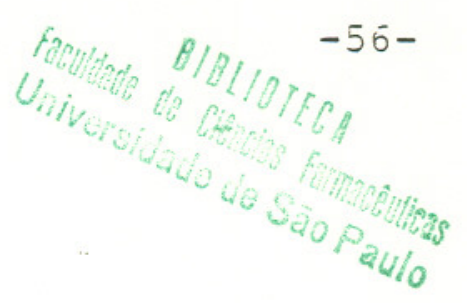

bém o balanço do enxofre para o feijão integral e para a fração albuminica, sendo a globulina Gl dispensada por possuir re duzido teor de aminoácidos sulfurados.

As Tabelas 11 e 12 mostram a ingestão e excreção fecal diārias do enxofre total para essas duas fontes protéicas. Os resultados mostram que apesar da ração à base de feijão integral conter um teor de enxofre $17 \%$ superior em relação à ração contendo albuminas, a ingiestão média diäria de enxofre total foi semelhante nos dois grupos de animais $(9,0$ e 9,2mg/dia/ /rato) pois a diferença foi compensada por uma maior quantidade de ração consumida pelos animais mantidos com a ração à base de albuminas.

A eliminação, calculada como porcentagem do enxofre ingerido, foi estatisticamente semelhante entre o feijão integral e as albuminas, sendo de 26,8 e 23,3\%, respectivamente.

A excreção de enxofre-35 determinada tambēm para a globulina Gl, apresentada nas Tabelas 11 a 13,elevou-se nos pri meiros três dias semelhante ao que aconteceu com $\circ{ }^{15} \mathrm{~N}$ atingindo após esse tempo um valor praticamente constante. Nesta fase estacionāria (do 4 9 ao 69 dia) o valor médio de excreção do ${ }^{35} \mathrm{~S}$ em relação ao ingerido, foi de $32,4,18,7$ e 6,7 respectivamente, para ○ feijão integral, albuminas e globulina Gl. 
TABELA 11 - Experiência 3 - Ensaio do feijão Integral: Ingestão e excreção fecal diárias de enxofre total e de ${ }^{35} \mathrm{~S}^{*}$.

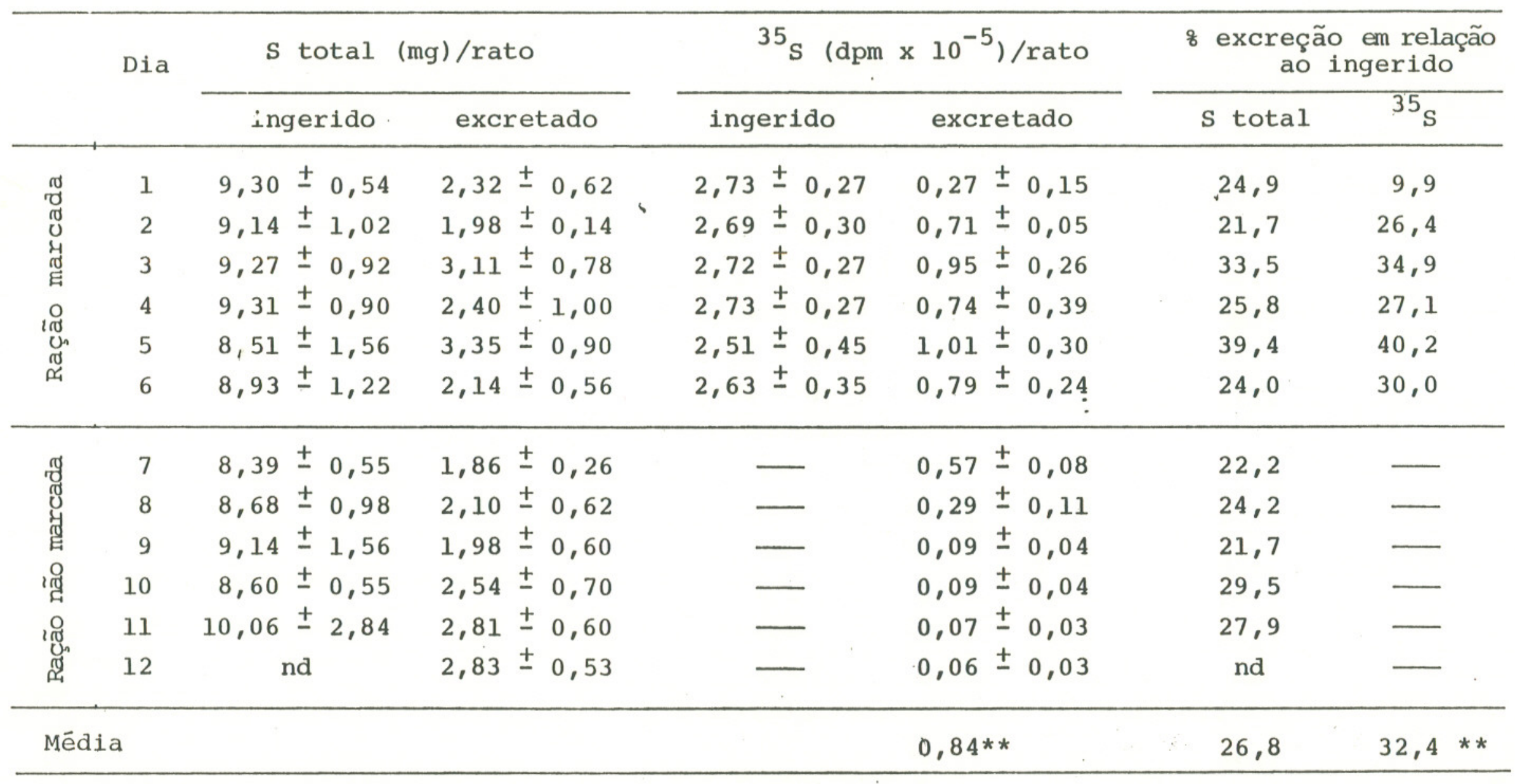

* Valores mëdios \pm desvio padrão $(n=4)$ Atividade do ${ }^{35} \mathrm{~S}$ na ração: $49,1 \mathrm{dpm} \cdot 10^{-5} / 100 \mathrm{~g}$ ** \& de excreção média de ${ }^{35} \mathrm{~S}$ na fase de equilíbrio ( 48 ao 68 dia) nd $=$ não determinado. 
TABELA 12 - Experiência 3 - Ensaio da fração albuminica: Ingestão e excreção fecal diārias de enxofre total e de ${ }^{35} \mathrm{~S}^{*}$.

\begin{tabular}{|c|c|c|c|c|c|c|c|}
\hline & \multirow{2}{*}{ Dia } & \multicolumn{2}{|c|}{$\mathrm{s}$ total $(\mathrm{mg}) /$ rato } & \multicolumn{2}{|c|}{${ }^{35} \mathrm{~s}\left(\mathrm{dpm} \times 10^{-5}\right) /$ rato } & \multicolumn{2}{|c|}{$\begin{array}{l}\text { \& excreção em } \\
\text { relação ao ingerido }\end{array}$} \\
\hline & & ingerido & excretado & Ingerido & excretado & S & ${ }^{35} \mathrm{~s}$ \\
\hline \multirow{6}{*}{ 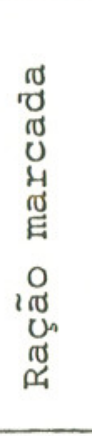 } & 1 & $7,98 \pm 0,58$ & $2,00 \pm 0,38$ & $4,15 \pm 0,30$ & $0,18 \pm 0,14$ & 25,06 & 4,36 \\
\hline & 2 & $7,98 \pm 0,78$ & $2,31 \pm 0,62$ & $4,16 \pm 0,40$ & $0,75 \pm 0,07$. & 28,95 & 18,00 \\
\hline & 3 & $8,05 \pm 0,82$ & $1,50 \pm 0,26$ & $4,19 \pm 0,42$ & $0,87 \pm 0,19$ & 18,63 & 20,74 \\
\hline & 4 & $8,32 \pm 0,68$ & $1,56 \pm 0,39$ & $4,34 \pm 0,35$ & $0,80 \pm 0,13$ & 18,75 & 18,34 \\
\hline & 5 & $9,69 \pm 1,13$ & $1,69 \pm 0,63$ & $5,05 \pm 0,59$ & $0,89 \pm 0,33$ & 17,44 & 17,58 \\
\hline & 6 & $9,83 \pm 1,02$ & $1,99 \pm 0,20$ & $5,13 \pm 0,53$ & $\begin{array}{c}1,03 . \\
\pm 0,11 \\
\end{array}$ & 20,24 & 20,17 \\
\hline \multirow{6}{*}{ 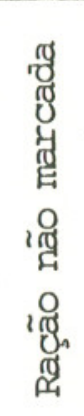 } & 7 & $9,48 \pm 1,59$ & $2,24 \pm 0,09$ & - & $0,75 \pm 0,08$ & 23,63 & - \\
\hline & 8 & $9,76 \pm 1,30$ & $2,76 \pm 0,53$ & - & $0,39 \pm 0,17$ & 28,28 & - \\
\hline & 9 & $9,83 \pm 1,24$ & $2,00 \pm 0,37$ & - & $0,21 \pm 0,05$ & 20,34 & - \\
\hline & 10 & $10,03 \pm 1,12$ & $2,24 \pm 0,46$ & - & $0,13 \pm 0,02$ & 22,33 & - \\
\hline & 11 & $10,03 \pm 0,76$ & $3,24 \pm 0,69$ & - & nd & 32,30 & - \\
\hline & 12 & nd & $1,68 \pm 0,37$ & - & $0,08 \pm 0,03$ & nd & - \\
\hline \multicolumn{2}{|c|}{ Média } & & & & $0,91 * *$ & $, 23,30$ & $18,70 * *$ \\
\hline
\end{tabular}

* Valores médios \pm desvio padrão $(n=4)$

Atividade do ${ }^{35} \mathrm{~S}$ na ração: $71,4 \mathrm{dpm} \cdot 10^{-5} / 100 \mathrm{~g}$

** $q$ de excreção média de ${ }^{35} \mathrm{~S}$ na fase de equilíbrio (48 ao 68 dia)

nd $=$ não determinado. 
TABELA 13 - Experiência 3 - Ensaio da globulina Gl: Ingestão e excreção fecal diārias de ${ }^{35} \mathrm{~S}$.

\begin{tabular}{|c|c|c|c|c|}
\hline & \multirow{2}{*}{ Dia } & \multicolumn{2}{|c|}{${ }^{35} \mathrm{~s}\left(\mathrm{dpm} \cdot 10^{-5}\right) /$ rato } & \multirow{2}{*}{$\begin{array}{l}\text { \% excreção en } \\
\text { relação ao in- } \\
\text { gerido }\end{array}$} \\
\hline & & ingerido & excretado & \\
\hline \multirow{6}{*}{ 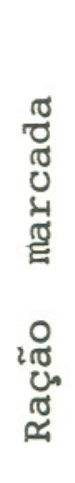 } & 1 & 0,611 & 0,004 & 0,65 \\
\hline & 2 & 0,582 & 0,038 & 6,53 \\
\hline & 3 & 0,527 & 0,024 & 4,55 \\
\hline & 4 & 0,533 & 0,035 & 6,57 \\
\hline & 5 & 0,889 & 0,051 & 5,74 \\
\hline & 6 & 0,889 & 0,069 & 7,76 \\
\hline \multirow{3}{*}{$\begin{array}{l}\pi \\
\pi \\
0 \\
0 \\
0 \\
0 \\
\Xi\end{array}$} & 7 & - & 0,031 & - \\
\hline & 8 & - & 0,033 & - \\
\hline & 9 & & 0,022 & \\
\hline i⿱乛龰 & 10 & 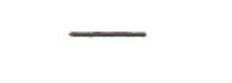 & 0,027 & - \\
\hline \multirow{2}{*}{ 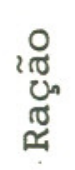 } & 11 & - & 0,013 & - \\
\hline & 12 & $\longrightarrow$ & 0,009 & - \\
\hline \multicolumn{2}{|c|}{ Média } & & $0,052 * *$ & $6,69 * *$ \\
\hline
\end{tabular}

* Valores médios de um "pool." de 4 animais.

Atividaçe do ${ }^{35} \mathrm{~S}$ na ração: $11,73 \mathrm{crm} \cdot 10^{-5} / 100 \mathrm{~g}$

** \& de excreção média na fase de "equilíbrio" (4\% ao $6 \%$ dia) 
8 - DISCUSSÃO

\section{1 - Propriedades nutricionais do feijão e digestibilidade de suas frações protēicas}

As experiências "in vitro", realizadas anteriormente, nos haviam mostrado que a globulina Gl e a fração glutelínica a presentavam uma melhora significativa na sua susceptibilidade ao ataque enzimātico, após o aquecimento; a fração albuminica, porém, contrariamente, sofria uma redução na velocidade de hidrólise enzimätica (Lanfer Marquez \&. Lajolo, 1981; Deshpande \& Nielsen, 1987c).

Podemos, agora, atravēs de novos ensaios, comparar aqueles resultados obtidos "in vitro" com a digestibilidade "in vivo" em ensaios com ratos, e tentar explicar algumas de suas propriedades nutricionais.

Assim, com as principais frações protēicas (albuminas, globulina Gl e glutelinas) do feijão Carioca, marcadas ou não isotopicamente, procuramos evidenciar primeiramente em ensaios com animais, os efeitos tanto da ingestão do feijão integral, como de suas proteinas isoladas, sobre os indices de digestibilidade e valor nutricional. A interpretação conjunta dos re- 
sultados de três experiências, permitiu delinear um comportamen to especifico para cada fonte protéica, que passaremos a discutir.

As Tabelas 5 e 6 e a Figura 1 mostram os resultados re ferentes a dois ensaios biológicos.

As albuminas e glutelinas parecem ser as frações protēicas mais interessantes sob o ponto de vista nutricional, pois promoveram "Ganhos de Peso" e valores de "NPR" maiores, superiores mesmo aos obtidos com $\circ$ feijão integral. Apesar dis so, os indices de "NPR" ainda são reduzidos, atingindo apenas $70 \%$ dos valores obtidos com a caseina.

Esses resultados não podem ser explicados somente com base nas diferenças de digestibilidade dessas fontes protéicas: a ração contendo a fração glutelínica mostrou uma digestibilida de significativamente inferior à da caseina, enquanto que a fra ção albuminica aṕresentou uma digestibilidade semelhante.

Dedicamos impoṛtância especial à discussão da globulí na Gl,por ser a proteina predominante do feijão e por ter mostrado uma digestibilidade elevada, semelhante à da caseína, mas um valor biológico muito reduzido, não permitindo o crescimento dos animais.

A presença de fatores antinutricionais, tais como ini bidores de tripsina, antiamilases e hemaglutininas, não. foi a causa do reduzido aproveitamento biológico, uma vez que não foram detectados em nenhuma das frações protéicas. O aquecimento utilizado para as proteinas ( $30 \mathrm{~min}$. em autoclave a $121^{\circ} \mathrm{C}$ ) foi suficiente: para eliminar totalmente a atividade antitriptica e 
hemaglutinante, apesar de poder ter causado uma perda do valor biológico, por reduzir a biodisponibilidade de aminoácidos essenciais, como discutiremos adiante.

A resistência da globulina Gl, crua, ao ataque enzimä tico, por enzimas digestivas de mamiferos, tem sido demonstrada por diversos autores (Chang \& Satterlee,1981; Lanfer Marquez \& Lajolo, 1981; Liener \&.Thompson, 1980; Romero e Ryan, 1978), representando importante fator ria reduzida digestibilidade do fei jão cru. Esse comportamento pode ser atribuido à sua estrutura tridimensional compacta, estabilizada ainda pela presença de carboidratos, causando um impedimento estērico, à aproximação da enzima (Chang \& Satterlee, 1981; Semino et al., 1985).

No entanto, o mesmo não se verifica após um tratamento tērmico adequado, quando então a fração Gl se torna altamen te susceptivel à hidrölise enzimätica "in vitro", fato descrito por diversos pesqưisadores e confirmado recentemente por Deshpan de e Nielsen, 1987b).

Outras hipóteses, que pudessem explicar a reduzida di gestibilidade de leguminosas, tais como: interação das proteinas com amido, minerais, àcido fítico e polifenóis tambēm jä foram aventadas (Boonvisut \& Whitaker, 1976; Deshpande et al., 1982; Aw \& Swanson, 1985), sendo pouco provável, no entanto ocorrerem na globulina purisicada e aquecida isoladamente.

O reduzido aproveitamento biológico da globulina Gl observado, talvez possa ser explicado pelo baixo teor de aminoácidos sulfurados nessa fração. Os teores encontrados por diversos autores tem sido discrepantes, variando entre 0,3 e $1,2 \mathrm{~g}$ 
metionina, e 0,0 e $1,1 \mathrm{~g}$ de cisteina por $\mathrm{l} 6 \mathrm{~g}$ de nitrogênio (Antul nes \& Sgarbieri, 1980; Barker et al., 1976; Bradbear \& Boulter, 1984; Chang \& Satterlee, 1981; Ericson \& Chrispeels, 1973; Lan fer Marquez \& Lajolo, 1981; Liener \& Thompson, 1980; Pusztai \& Watt, 1970).

Essas diferenças nos teores em aminoácidos sulfurados podem ser. atribuidas às variações nas técnicas de extra ção e purificação associadas ào reduzido teor desses aminoãci dos nessa fração, dificultando o seu doseamento. Não pode ainda ser excluída a variação real no teor desses aminoácidos, devida à variedade estudada.

De qualquer forma, mesmo na melhor das hipöteses, o cômputo químico dos aminoácidos sulfurados da globulina Gl, em relação à proteỉna do ovo, não passa de $40 \%$.

Esta situação pode ser agravada por uma reduzida biodisponibilidade desses aminoácidos limitantes nos feijões, em torno de $50 \%$ para a metionina e de 40 a $75 \%$ para a cisteina (Evans et al., 1974; Evans \& Bauer, 1978; Liener, 1976). Sgar bieri et al. (1979), relatam valores ainda menores, variando entre 29,3 a 40,6\% para a metionina, em função da variedade de feijão estudada.

Preocupamo-nos em seguida com a fração Gl e o seu des tino no organismo animal. A literatura cientifica concernente (apesar de existirem poucos trabalhos publicados), indica uma boa digestibilidade aparente e um valor biológico reduzido (Lie ner \& Thompson, 1980). O conjunto de informações obtidas sobre a fração Gl e a experiência por nós realizada, parecem confir- 
mar que a reduzida utilização biológica da globulina Gl isolada, não è causada por um impedimento na sua hidrôlise enzimática "in vivo" .

Alēm da deficiência em aminoācidos sulfurados, uma re dução da biodisponibilidade de outros aminoácidos essenciais pode ser prevista. O elevado teor de carboidratos na fração globulina Gl (12\%) e a elevada reatividade de carbonilas, permi tem reações de condensação carb̈onil-amina e formação de produ tos de Amadori (Reação de Maillard), reduzindo também a disponibilidade da lisina, originalmente presente na globulina Gl em quantidades suficientes. O efeito do aquecimento em autoclave a $121^{\circ} \mathrm{C} / 30$ min. foi demonstrado por Antunes e Sgarbieri (1980) . Nessas condições uma farinha de feijão Rosinha G2 (Phaseolus vulgaris) mostrou uma queda na biodisponibilidade da lisina, de 42\%. Esse tratamento levou a uma destruição completa dos inibi dores de tripsinare das fitohemaglutininas, apesar do melhor valor biológico em ratos, ter sido obtido após aquecimento por apenas 10 min. a $97^{\circ} \mathrm{C}$, quando uma quantidade considerävel da ati vidade antitriptica e hemaglutinante ainda estava presente.

Para o feijão integral os indices de valor nutricional observados foram reduzidos, bem como a sua digestibilidade (ao redor de 70\%) indicando haver problemas de aproveitamento . Cabe rersiltar tambēm a elevada excreção fecal determinada em matéria seca ou em nitrogênio, 3 a 4 vezes superior àquela causada pela ingestão da ração controle de caseina, e mesmo muito superior àquela dos animais alimentados com as proteinas isoladas. 
Os resultados quanto à eliminação fecal foram apresen tados para mostrar que as frações protēicas isoladas são capa zes de causar apenas um discreto aumento na excreção, ocorrendo o inverso porēm, apōs a ingestão de feijão integral. Paralela mente ao ensaio do feijão integral foi incluído também, um grupo de animais alimentados com uma ração a base de feijão integral adicionado da fração albuminica. O melhor desempenho da albumina, sob $\circ$ ponto de vista'nutricional, nos induziu a pensar que a adição dessa proteina pudesse melhorar o aproveitamento bio lógico do feijão integral. Essa hipōtese se justifica pelo menos em parte, uma vez que a albumina possui aproximadamente 25\% dos aminoācidoss sulfurados totais presentes no feijão.

Os resultados observados nesses animais, no entanto, não mostraram diferença significativa $(P \leqslant 0,05)$ na digestibili dade, "NPR" (utilização protéica líquida) e Ganho de Peso.

Esses dados podem ser interpretados como indicativos da existência de algum componente presente no feijão integral , ou de algum mecanismo a nivel intestinal, levando à formação de complexos protéicos indigeríveis, com possivel cömprometimen to da biodisponibilidade da metionina, ou então, estimulando a secreção de nitrogênio endógeno.

Os resultados de Kakade \& Evans (1966), apoiam de certa forma a hipötese da excreção endEyena: a análise do conteúdo intestinal de ratos que haviam recebido uma dieta contendo feijões cozidos, mostrou que o nitrogênio total excretado nas fezes, representava cerca de $40 \%$ do total ingerido com a ração. 
Resultados semelhantes foram descritos por Bressani et al. (1977); Bender \& Mohammadiha (1981) e Fairweather-Tait et al., (1983), e, mesmo em humanos, foram feitos relatos sobre a elevada excreção fecal de nitrogênio apōs a ingestão de dietas a base de feijão (Navarrete \& Bressani, 1981 e Rosales A $z \overline{\text { ú, }}$ 1977).

o terceiro ensaio biológico teve como finalidade estụ dar, a niviel de excreção, o dëstino do nitrogênio e enxofre pró venientes do feijão e das suas frações protēicas, diferencian do-os daqueles de origem endógena, pelo emprego de is.ótopos. Es te mesmo ensaio foi tambëm utilizado para reavaliar a digestibi lidade e utilização biológica pela metodologia convencional.

A anālise dos resultados (Tabela 7), permitiu afirmar que não houve diferenças significativas em relação aos dois ensaios anteriores: isto è,o feijão integral apresentou a menor digestibilidade "real" (67\%) seguido da fração albumina ( $83 \%$ ) e da globulina Gl (9.5\%); ○ "NPR" da albumina foi significativa mente maior do que das demais fontes protëicas do feijão, o que vem comprovar mais uma vez a superioridade nutricional des ta fração em relação ao feijão integral. o valor biológico das albuminas, foi de $71 \%$ em relação ao controle de caseina e pode estar limitado ainda, por reações entre carboidratos e protei nas, ou mesmo entre taninos e proteỉnas com formação de estrutū ras não digeriveis pelas enzimas digestivas.

E oportuno comentar que a concentração de glicides, determinada na fração albuminica, foi muito elevada (30mg/100mg proteina), favorecendo reações do tipo Maillard, durante o tra- 
tamento térmico (30 min. em autoclave a $121^{\circ} \mathrm{C}$ ). Semino et al. , (1985), relatam a redução da proteólise da globulina de Lupinus albus (tremoço) pela triṕsina, na presença de carboidratos liga dos, e um aumento na liberação de pequenos peptideos solúveis em TCA, proporcional à quantidade de carboidratos removidos por via enzimática. O trabalho de Evans \& Bauer (1978) comenta também a existência de um fator de baixo peso molecular, dialisável, presente em extratos aquosos, ćapaz de inibir o crescimento de ratos, mesmo após tratamento tērmico.

o valor biológico da globulina Gl, novamente, foi mui to reduzido, podendo este quadro ter sido agravado, pelo baixo consumo de ração, associado a uma ingestão calórica inferior ao valor recomendado para ratos, em crescimento, levando os animais a uma desnutrição protéico calórica progressiva (Rogers , 1979; NATIONAL RESEARCH COUNCIL. Nutrient requirements of the laboratory rat, 1972). Já a ingestão de ração está intimamente relacionada com a palatabilidade e o seu valor biológico.

Enquanto os animais alimentados com caseina mantive ram uma ingestão calórica adequada ao crescimento, o mesmo não acontecia com os animais que ingeriram as rações experimentais. Os cálculos mostraram que os animais alimentados com o feijão e com as albuminas, receberam respectivamente, 84 e $88 \%$ de suas necessidades calóricas, enquanto que os animais sustentados por uma ração à base de globulina Gl receberam apenas $70 \%$ da quanti dade de energia ideal para manter um crescimento satisfatório . Considerou-se para esses cálculos, um aporte calörico de $416 \mathrm{Kcal}$ /100g ração e a seguinte relação para animais a partir do desma me até o peso de 155g: 
$(\text { Peso animal) })^{0,882}=$ ingestão calörica diāria adequada

Nessa experiência observamos novamente a elevada excreção fecal causada pela ingestão do feijão integral, quatro ve zes superior a da caseina e decrescente na seguinte ordem: glutelinas > albuminas > caseina $\cong$ globulina Gl.

Fato esperado foi a observação de uma relação direta entre o teor de fibra nas rações e a excreção fecal de matēria seca. A presença de outros componentes no feijão levou a um aumento de matéria fecal e ém decorrência provocou, nos animais alimenta dos com a ração de feijão, um aumento paralelo de nitrogênio excretado (Quadro I e Figura 2). Este fato sugere ocorrer uma complexação da proteina com esses componentes, tornando-a inaproveitāvel ao organismo animal, ou mesmo, um incremento na secreção de proteínas de origem endögena.

QUADRO I - Relação entre a excreção fecal e o teor de fibra da dieta*

\begin{tabular}{|lccc|}
\hline $\begin{array}{c}\text { Fonte } \\
\text { Protēica }\end{array}$ & $\begin{array}{c}\text { Matëria fecal seca } \\
\text { mg/g ração }\end{array}$ & $\begin{array}{c}\text { Matéria seca fecal/ } \\
\text { /Nitrogênio fecal }\end{array}$ & $\begin{array}{c}\text { \% } \text { Fibra dieta } \\
\text { da }\end{array}$ \\
\hline Feijão integral & 134,1 & 22,5 & 14,5 \\
Glutelinas & 68,4 & 17,5 & 7,4 \\
Albuminas & 57,5 & 18,9 & 6,2 \\
Globulina Gl & 46,1 & 22,2 & 3,1 \\
Caseina & 36,4 & 25,9 & 1,0 \\
\hline
\end{tabular}

* Média dos valores das três experiências. 


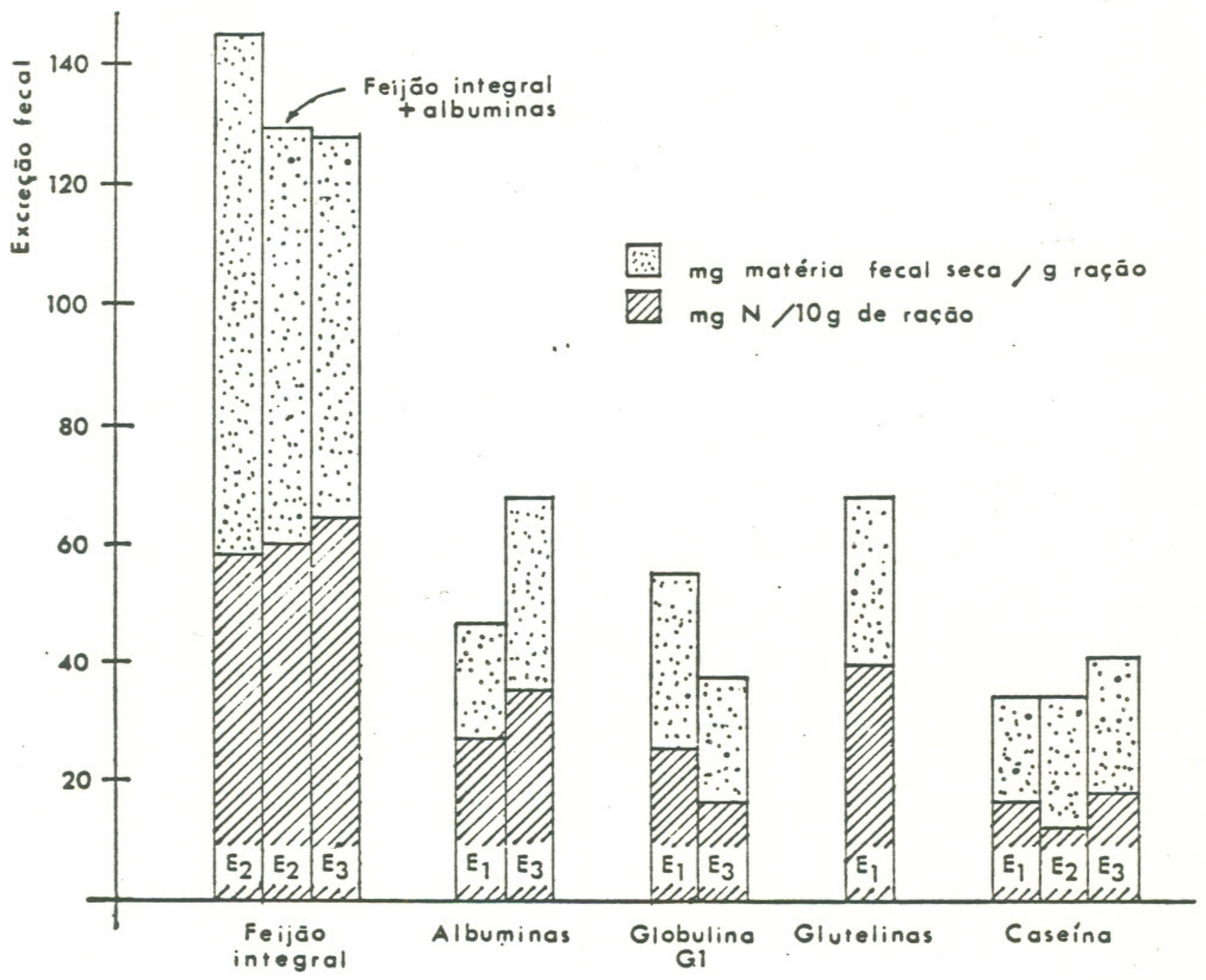

FIGURA 2 - Efeito da ingestão das rações contendo feijão integral ou suas proteínas isoladas, sobre a excreção fecal de matēria seca e de nitrogênio. Experiência l:El; Experiência 2-E2; Experiência 3:E3. 
8.2 - Efeito do feijão integral, das albuminas e da globulí na Gl, na perda de nitrogênio total e nitrogênio-15

Com a metodologia empregada nos experimentos realiza dos, baseada no șimples balanço entre o nitrogênio ingerido e excretado, não foi possível identificar a origem do nitrogênio fecal dos animais que ingeriram rações à base de feijão e de suas frações protéicas isoladäs.

A exploração dos resultados da terceira experiência com o emprego de proteínas marcadas, foi útil, porém, para explicar os resultados: se relacionados com a reduzida digestibilidade do feijão e (ou) com as elevadas perdas fecais de nitrogênio : endógeno.

As Tabelas 8 a 10 mostram as anālises diărias relativas à ingestão e excreção de nitrogênio total e ${ }^{15} \mathrm{~N}$.

Oś valores de excreção fecal de ${ }^{15} \mathrm{~N}$, doze horas após o início da ingestão da ração marcada, forneceram dados sobre a participação do ${ }^{15} \mathrm{~N}$ proveniente da dieta.

A escolha da's doze horas para efetuar a primeira anälise isotópica, baseou-se nos trabalhos de Souffrant et al., (1981); Zimmer et al., (1975) e Zebrowska et al., (1976) que consideram a reciclagem do ${ }^{15} \mathrm{~N}$, durante as 16 horas iniciais, muito reduzida, considerando ser o nitrogênio marcado e excretado neste periodo, quase exclusivamente proveniente da dieta.

A excreção fecal de ${ }^{15} \mathrm{~N}$ nessas primeiras 12 horas foi reduzida, mas variável para as três rações experimentais, e os 
valores encontrados podem ser interpretados comparativamente . Os animais que receberam o feijão integral, excretaram nestas 12 horas, $9 \%$ do ${ }^{15} \mathrm{~N}$ ingerido; os animais que ingeriram a ração contendo as albuminas eliminaram $4 \%$ e aqueles alimentados com a globulina Gl excretaram menos do que $1 \%$ do ${ }^{15} \mathrm{~N}$, ingerido nesse mesmo periodo.

Apesar dos desvios da média de quatro animais em cada grupo experimental, estes resurltados podem representar uma dife rença na excreção do ${ }^{15} \mathrm{~N}$ originārio da dieta: a ingestão de feijões cozidos causou uma elevada excreção de nitrogênio prove niente do próprio feijão (aproximadamente 10 vezes superior aque : la provocada pela ingestão de globulina Gl) acompanhada tambēm de uma alta excreção de nitrogênio endógeno, sendo a soma de am bas, responsāvel pela excreção dos $34 \%$ do nitrogênio ingerido.

Conclusões semelhantes se obtēm, calculando-se a diluição isotōpica que ${ }^{15} \mathrm{~N}$ da ração sofreu ao passar pelo trato gastro-intestinal. No Quadro II estão apresentadas as concen trações isotópicas das três rações e das fezes colhidas 12 horas após o início da ingestão das rações marcadas, expressas em átomos \& de ${ }^{15} \mathrm{~N}$ em excesso.

Observamos nesse quadro que $0^{15} \mathrm{~N}$ fecal, proveniente do feijão integral, foi diluído 3,9 vezes com o nitrogênio não marcado; o nitrogênio proveniente das albuminas em 5,8 vezes e - da globulina Gl em 17,8 vezes. Estes valores indicam que 0 ${ }^{15} \mathrm{~N}$ excretado em concentração muito reduzida nas fezes dos animais que haviam recebido a ração à base de globulina Gl vem con firmar não haver problemas de digestão e (ou) absorção dessa frą 
QUADRO II - Diluição isotópica do ${ }^{15} \mathrm{~N}$ das rações, pela passagem no trato gastro-intestinal dos animais.

\begin{tabular}{|c|c|c|c|c|}
\hline $\begin{array}{l}\text { Fonte } \\
\text { protēica }\end{array}$ & $\begin{array}{l}{ }^{15} \mathrm{~N} \text { na } \\
\text { ração* }\end{array}$ & $\begin{array}{l}15_{\mathrm{N}} \text { nas } \\
\text { fezes** }\end{array}$ & $\begin{array}{l}\text { Fator de } \\
\text { diluição } \\
\text { do } 15 \mathrm{~N}\end{array}$ & $\begin{array}{l}\text { Excreção fecal } \\
\text { de } \mathrm{N} \text { total } \\
\left({ }^{14} \mathrm{~N}+{ }^{15} \mathrm{~N}\right) \\
\text { (\% da ingestão) }\end{array}$ \\
\hline $\begin{array}{l}\text { Feijão inte- } \\
\text { gral }\end{array}$ & 0,493 & 0,125 & 3,9 & 34 \\
\hline Albuminas & 1,076 & 0,185 & 5,8 & 20 \\
\hline $\begin{array}{l}\text { Globulina } \\
\text { Gl }\end{array}$ & 0,498 & 0,028 & 17,8 & 11 \\
\hline
\end{tabular}

* Atomos o de ${ }^{15} \mathrm{~N}$ em excesso.

* Fezes coletadas 12 horas após o início da ingestão da ração marcada; teor expresso em ätomos o de ${ }^{15} \mathrm{~N}$ em excesso.

ção protēica do fẹijão. Nesse caso, a elevada diluição isotōpi ca do nitrogênio marcado na ração, evidencia que o nitrogênio endógeno representa uma elevada porcentagem da quantidade total de nitrogênio excretada. No entanto, a reduzida quantidade de nitrogênio eliminada, pelos animais que ingeriram a globulina Gl, sugere que a proteina predominante do feijão, pouco contri bui na elevada excreção de nitrogênio decorrente da ingestão do feijão integral.

A ração à base de albuminas do feijão evocou, nos ani mais que a ingeriram, uma resposta intermediāria, com significa tiva participação tanto do nitrogênio exógeno como do endógeno. 
ratos, indicam que, mesmo até 8 horas após a ingestão de uma ração à base de cevada, a excreção fecal de dicromato, utilizado como indicador não absorvivel, não ultrapassou $10 \%$ do ingeri do. Apesar dessa critica relativa à possibilidade do esvazia mento incompleto do intestino grosso, 12 horas apōs a ingestão, a anālise fecal ém tempos mais longos forneceria um valor para - ${ }^{15} \mathrm{~N}$ da dieta, falseado (aumentado) pela secreção de nitrogênio endógeno, jā marcado isotọpicamente.

Nas Tabelas 8 a 10 observamos ainda um aumento na excreção diāria de ${ }^{15} \mathrm{~N}$, atingindo um "estado quase-estacionārio" dentro de três dias, no qual a relação entre $0^{15} \mathrm{~N}$ ingerido e o excretado se manteve aproximadamente constante, para cada dieta experimental. Assim, o valor dessa relação foi de $29,4 \%$ para o feijão integral, 14,8\% para as albuminas e de apenas 3,5\% para - globulina Gl. Nessa fase "quase estacionária" os valores de excreção de ${ }^{15} \mathrm{~N}$ jạ contém, além de ${ }^{15} \mathrm{~N}$ proveniente da dieta, um componente de origem endógena marcado isotopicamente. As diges tibilidades calculadas a partir desses dados, através do balanço entre $\circ{ }^{15} \mathrm{~N}$ ingerido e excretado, representariam "digestibilidades aparentes", e jã não distinguem a origem do ${ }^{15} \mathrm{~N}$ fecal. Na Figura 3, encontramos as diferenças na excreção de ${ }^{15} \mathrm{~N}, 12$ horas após o início da ingestão das rações marcadas e na fase de equilibrio.

Comparando-se o nivel de excreção de ${ }^{15} \mathrm{~N}$ (em relação ao ingerido) com $\circ$ do $\mathrm{N}$ total $\left({ }^{14} \mathrm{~N}+{ }^{15} \mathrm{~N}\right)$, observamos para $\bigcirc \mathrm{N}$ total, uma excreção constante durante o periodo de ensaio, embora a quantidade de $\mathrm{N}$ total excretada tenha sido diferente para cada fonte protéica. Assim, os animais que receberam feijão 


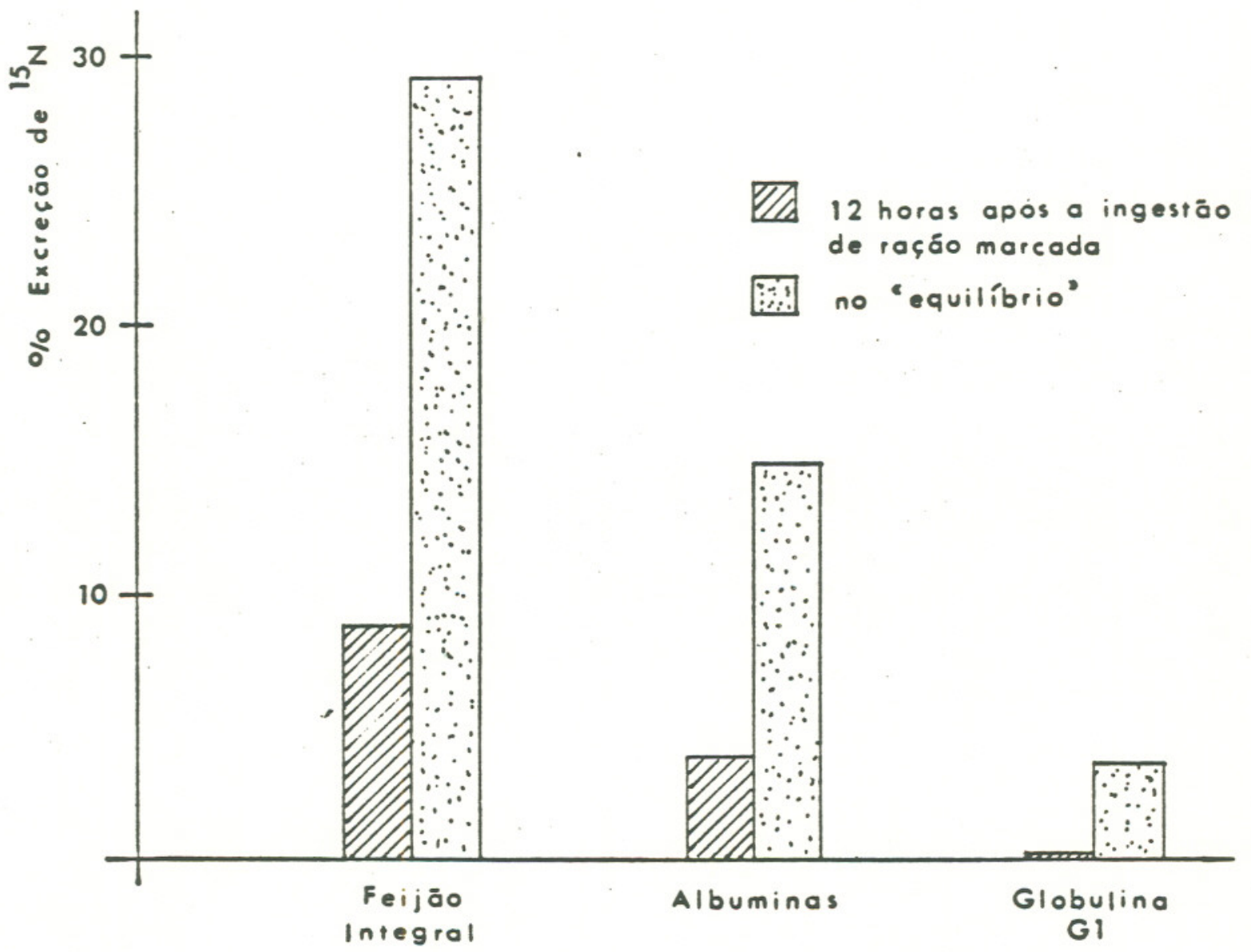

FIGURA 3 - Excreção fecal de ${ }^{15} \mathrm{~N}$ (percentagem da ingestão média diāria) 12 horas apōs o início da ingestão da ração marcada e na fase de equilibrio (40 ao $6 \%$ dia da experiêncici). 
integral, apresentaram uma excreção de $\mathrm{N}$ total muito elevada, da ordem de $34,4 \%$. Na fração albuminica a excreção foi de $20,4 \%$ e para a globulina Gl de 10,7\%.

Já o nível de excreção do ${ }^{15} \mathrm{~N}$ na fase de equilibrio (49 ao 69 dia) foị inferior ao do $\mathrm{N}$ total. No feijão integral e nas albuminas, a diferença foi de 15 e $18 \%$ respectivamente, e para a globulina Gl da ordem de 67\%. Embora a diferença encontrada na globulina Gl entre $0^{.15} \mathrm{~N}$ e $\circ \mathrm{N}$ total excretados, seja muito grande, possivelmente, foi causada pela reduzida excreção de ${ }^{15} \mathrm{~N}$, dificultando a análise e elevando o erro analítico; a digestibilidade aparente para $\circ \mathrm{N}$ total e $0^{15} \mathrm{~N}$ calculada dessa forma variou no entanto de apenas $91 \%$ para $96 \%$.

Em trabalho recente, realizado no Brasil, Costa de Oliveira \& Sgarbieri (1986b), estudando a interferência do $\mathrm{N}$ en dógeno na digestibilidade e no valor biolögico do feijão ou de seu extrato protéíco, cru ou autoclavado, relataram que a diges tibilidade e o valor biológico calculados a partir do balanço de ${ }^{15} \mathrm{~N}$ ingerido e excretado em ensaio com ratos, durante 4 dias, foram superiores em relação aos valores baseados no nitrogênio total. Estes autores acreditam não haver secreção de nitrogênio endógeno marcado, durante os quatro dias do experimento, de modo que a digestibilidade calculada com base no ${ }^{15} \mathrm{~N}$, representaria a digestibilidade real do feị̂ão.

No entanto, a diferença na excreção de $\mathrm{N}$ total e ${ }^{15_{\mathrm{N}}}$ pode ser explicada de outras formas: é possivel ocorrer uma re tenção de parte do ${ }^{15} \mathrm{~N}$ absorvido, pela própria parede intesti nal, sem ingressar no "pool nitrogenado". Rerat et al. (1980), 
demonstraram em porcos, que 10-15\% dos aminoácidos livres são retidos pela mucosa intestinal, principalmente do intestino del gado.

Anteriormente, Krawielitzki (1972) tambēm jā havia oḅ servado em ratos, que receberam uma dieta contendo metionina mar cada, que $14 \%$ da metionina ingerida, ficavam retidos na parede gastro-intestinal. Acredita o autor, que esta metionina absorvida seja rapidamente incorporada nas secreções digestivas, reexcretada e submetida novamente aos processos de degradação e absorção.

Outra hipótese e que complementa a anterior, seria a de uma incorporação de ${ }^{1 \zeta_{\mathrm{N}}}$ em proteínas musculares ou em protei nas dos pelos dos animais em crescimento, que sabidamente possuem uma reduzida atividade metabólica, retirando este ${ }^{15} \mathrm{~N}$ de circulação. Desta forma $\circ{ }^{15} \mathrm{~N}$ não teria atingido ainda um esta do de equilibrio to organismo animal.

A análise da excreção fecal de ${ }^{15} \mathrm{~N}$, durante a fase do experimento na qual os animais jā voltaram a receber ração não marcada (78 ao 128 dia), forneceu informações sobre a velocidade de excreção do nitrogênio marcado.

Assim, apresentamos na Figura 4 as curvas de excreção do ${ }^{15} \mathrm{~N}$ em relação ao valor médio de ${ }^{15} \mathrm{~N}$ ingerido diariamente. $\mathrm{A}$. concuntração isotōpica fecal correspondente ac feijão integral e às albuminas, mostrou a partir do 60 dia uma fase inicial de queda rápida da concentração de ${ }^{15} \mathrm{~N}$. 


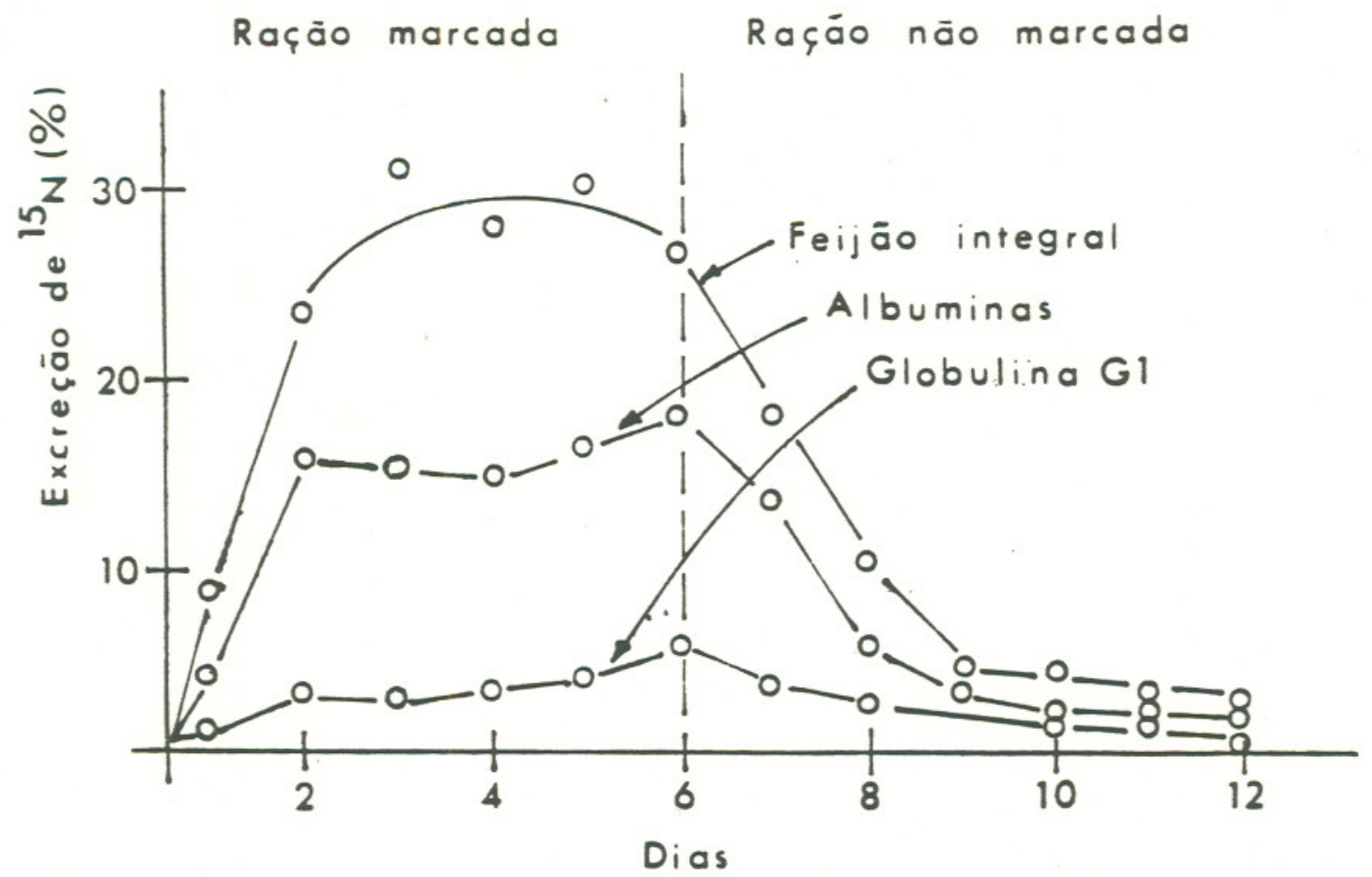

FIGURA 4 - Curvas de excreção fecal de ${ }^{15} \mathrm{~N}$ ( $\%$ da ingestão média diária) dos animais $(n=4)$, alimentados com feijão in tegral, albuminas e globulina Gl.

Na Figura 5 representamos os valores de ${ }^{15} \mathrm{~N}$ fecais, on tidos a partir do $6 \%$ dia, em escala semilogaritmica contra o tempo no qual ocorreu a excreção. Obtivemos curvas que mostram entre o $6 \%$ e 09 9 dia as velocidades correspondentes à eliminação de ${ }^{15} \mathrm{~N}$ endögeno + exögeno. Nesse período, as curvas correspondentes ao feijão integral e à fração albuminica, foram praticamente paralelas, ocorrendo redução de $50 \%$ da concentração do ${ }^{15} \mathrm{~N}$ fecal em aproximadamente 24 horas. A partir do 99 dia a eliminação do ${ }^{15} \mathrm{~N}$ foi aparentemente mais lenta, correspondendo $\mathrm{k}$ incipalmente do ${ }^{15} \mathrm{~N}$ de origem endógena.

A globulina Gl, por sua vez, mostrou entre $\circ 6 \%$ e $\circ$ 120 dia, uma velocidade menor de eliminação de ${ }^{15} \mathrm{~N}$ fecal, com uma "meia-vida" de aproximadamente 48 horas. Nesse caso a ele- 


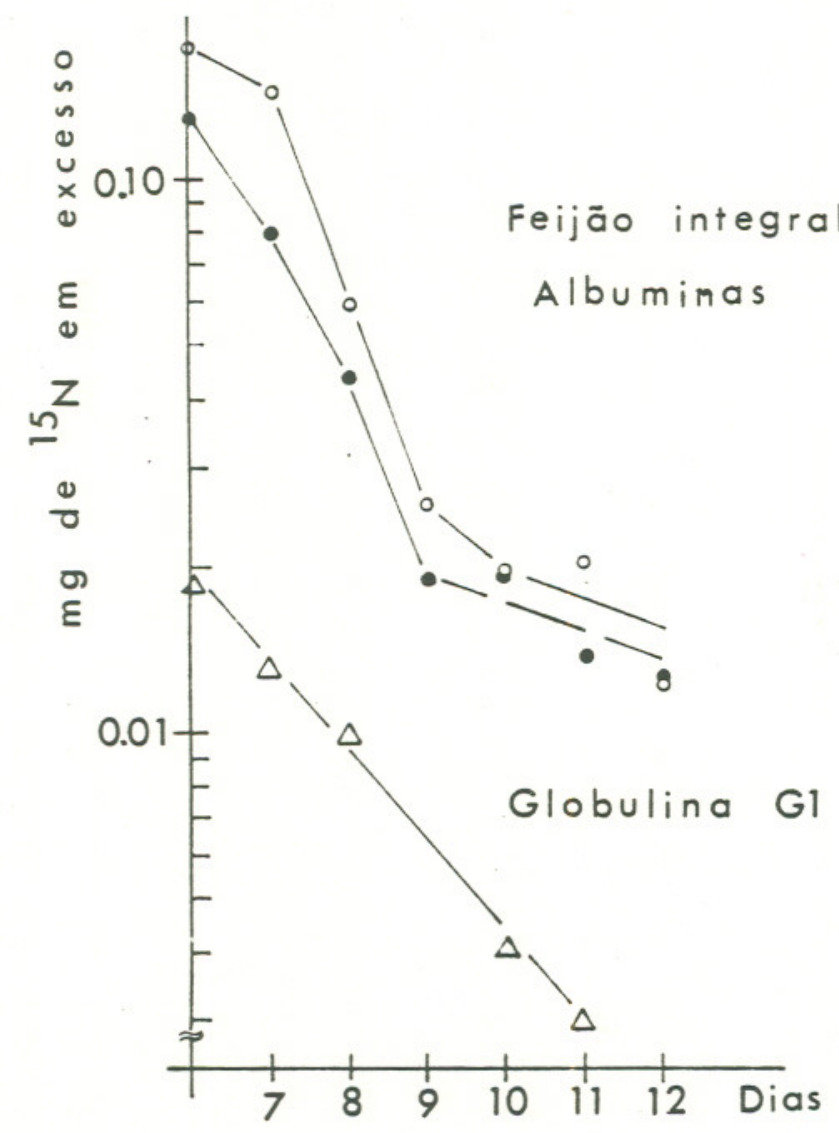

FIGURA 5 - Redução da concentração de ${ }^{15} \mathrm{~N}$ nas fezes, durante a fase de decaimen to $(6 \%-12 \%$, dia), dos animais alimentados com feijão integral, albuminas e globulina Gl.

vada digestibilidade da globulina Gl, determina uma participação predominante de ${ }^{15} \mathrm{~N}$ endógeno durante a fase de decaimento (do 69 ao 12 ? dia).

8.3 - Efeito do feijão integral, das albuminas e da globulina Gl na eliminação de enxofre.

Concomitante à anālise do nitrogênio total e do ${ }^{15} \mathrm{~N}$, acompanhamos a excreção fecal do enxofre total e do seu isótopo radioativo ${ }^{35} \mathrm{~S}$, com a finalidade de detectar algum desvio na metabolização dos aminoácidos sulfurados em relação ao nitrogênio total, que ajudasse explicar a reduzida biodisponibilidade desse 
aminoácido.

Os efeitos da ingestão das três fontes protéicas sobre a eliminação fecal diāria do enxofre total estão apresenta dos nas Tabelas 11 e 12. Verificamos que, tanto os animais que receberam o feijão integral, como aqueles alimentados com a fração albuminica, excretaram respectivamente, 26,8 e 23,3\% do enxofre total ingerido. Este balanço não foi realizado com a globulina Gl, por possuir teor.de enxofre total muito reduzido.

Nas Tabelas 11 a 13 apresentamos os dados relativos à ingestão e excreção fecal de ${ }^{35} \mathrm{~S}$. Incluimos nesse balanço a globulina Gl, pois a sensibilidade da análise isotópica permitiu a sua determinação quantitativa.

A excreção do ${ }^{35} \mathrm{~S}$ durante as primeiras 12 horas após - início da ingestão da ração marcada, foi semelhante à observa da para ${ }^{15} \mathrm{~N}$. Os grupos de feijão integral, albuminas e globu lina Gl excretaram respectivamente, $9,9 \%, 4,3 \%$ e $0,6 \%$ do ${ }^{35} \mathrm{~s}$ in gerido, e que consideramos ser de origem exógena.

Raciocinio semelhante ao adotado para ${ }^{15} \mathrm{~N}$, permitiu calcular a diluição que $0^{35} \mathrm{~S}$ da ração sofreu ao passar pelo trato gastro-intestinal. Apresentamos no Quadro III a relação entre $\circ$ enxofre total e $\circ{ }^{35} \mathrm{~S}$ nas rações e nas fezes coletadas 12 horas após o início da ingestão das rações marcadas.

observamos, um aumento da relação $s$ total $/^{35} \mathrm{~s}$ nas fezes dos animais que ingeriram o feijão integral ou as albuminas, - que significa uma diluição do ${ }^{35}$ S proveniente da ração por en xofre não marcado de origem endógena. Assim, quanto maior for a diluição, maior será tambēm a participação da secreção enđógena. . 
QUADRO III - Diluição isotōpica do ${ }^{35}$ S das rações, pela passagem no trato gastrointestinal dos animais.

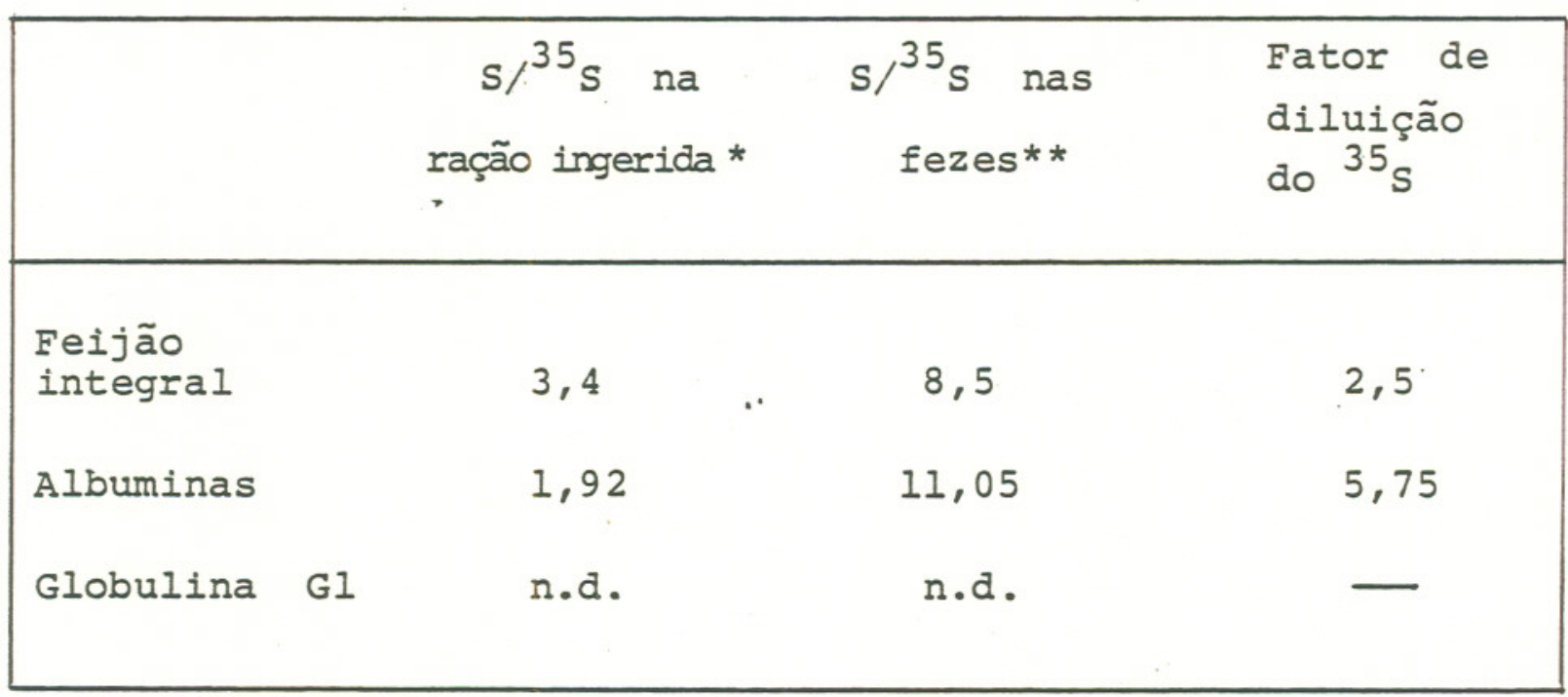

$n \cdot d=$ não determinado

${ }^{*} \mathrm{mg} \mathrm{s} / \mathrm{dpm} \cdot 10^{-5}$ ingeridos durante as primeiras 12 horas

** fezes coletadas 12 horas após o início da ingestão da ra ção marcada.

As curvas de eliminação do ${ }^{35}$ s para as três rações eś tão representadas na Figura 6 , com a finalidade de compará-las às curvas de excreção do ${ }^{15} \mathrm{~N}$. O comportamento do ${ }^{35} \mathrm{~S}$ foi semelhante ao do ${ }^{15} \mathrm{~N}$, apesar de ser excretado em niveis levemente supeitiores, o que poderá causar, a longo prazo, uma depleçao de sulfurados. 


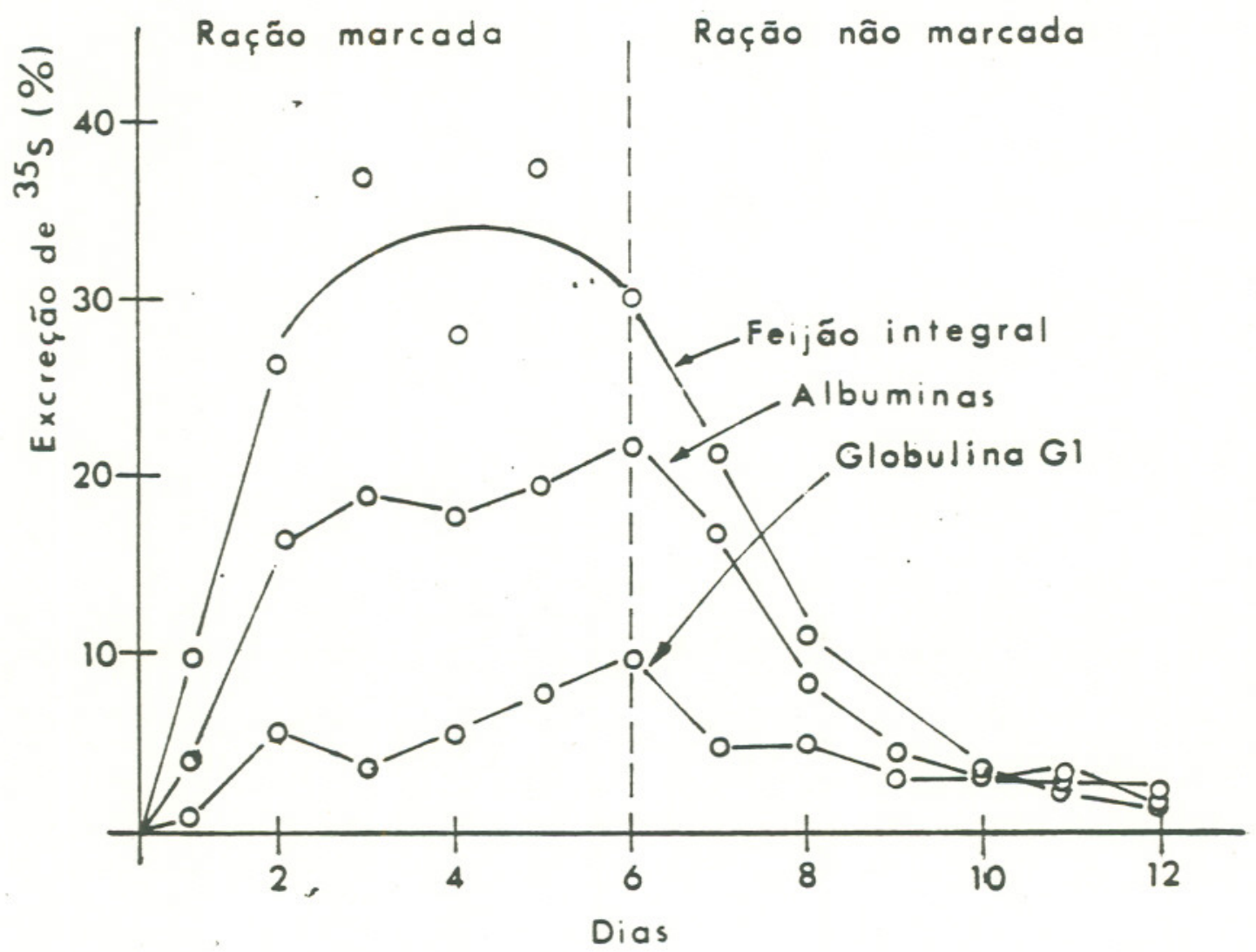

FIGURA 6 - Curvas de excreção fecal de ${ }^{35} \mathrm{~S}$ (\% da ingestão mê dia diäria) dos animais $(n=4)$ alimentados com $f e \underline{i}$ jão integral, albuminas e globulina Gl. 
Na Figura 7 observamos que ambas as rações (feijão in tegral e albuminas) provocaram nos 3 dias subsequentes à suspensão da ração marcada (69 ao 9\% dia), um rápido declínio da atividade isotōpica, semelhante ao obtido para ${ }^{15} \mathrm{~N}$ (redução da atividade para $50 \%$ em \pm 24 horas). A eliminação de ${ }^{35} \mathrm{~S}$, aparen temente mais lenta a partir do 99 dia,sugere novamente ter se esgotado $\circ{ }^{35} \mathrm{~S}$ proveniente do próprio feijão ou da fração albuminica, sendo ${ }^{35} \mathrm{~s}$ eliminado, proveniente de fontes endögenas.

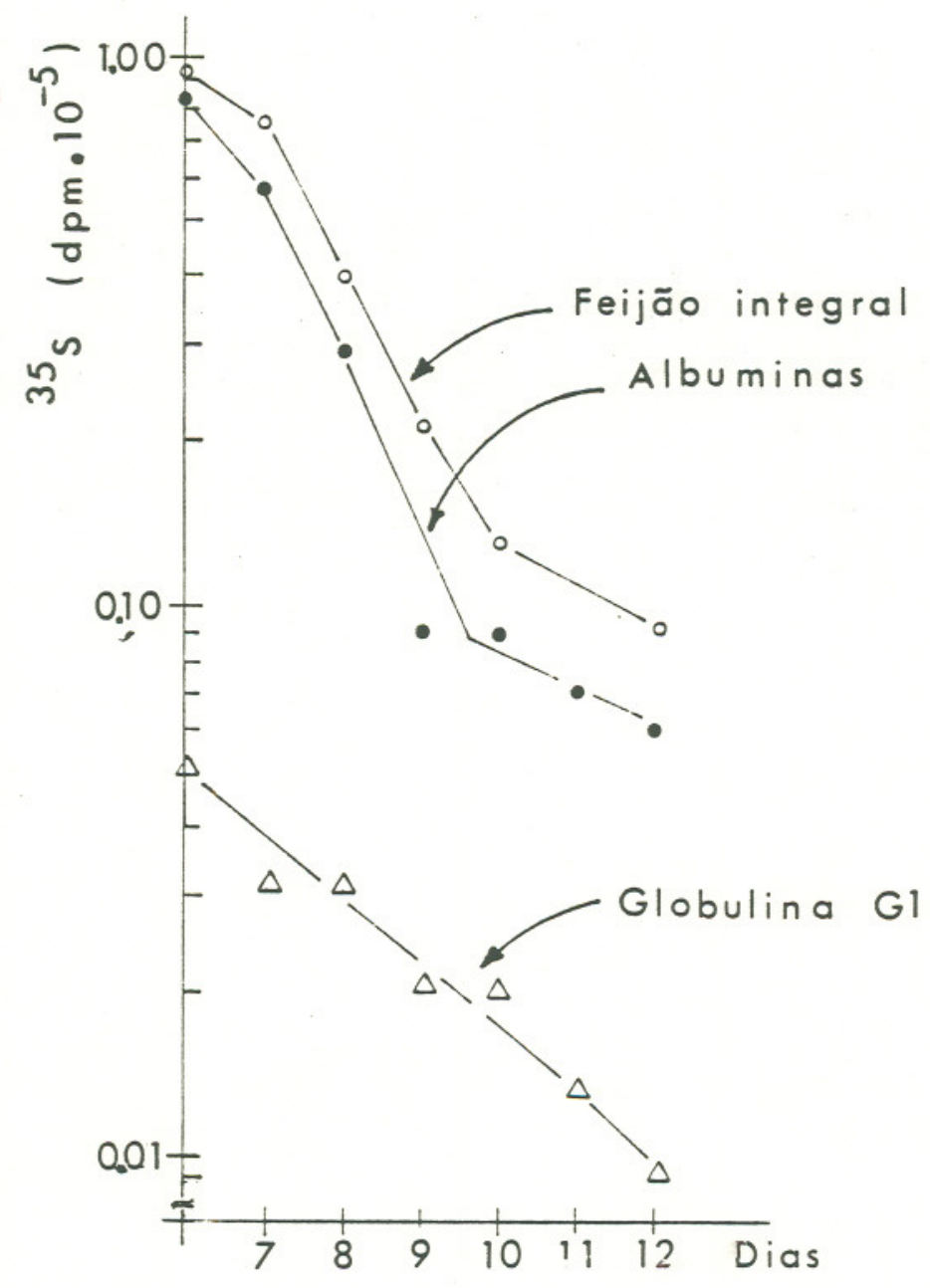

FIGURA 7 - Redução da atividade isotópica do ${ }^{35}$ S nas fezes, durante a fase de decaimento (6\%-12\% dia), dos animais alimentados com feijão integral, albuminas e globulina Gl. 
A reduzida excreção isotópica fecal manifestada pela ingestão da globulina Gl, torna impreciso o cálculo da "meia-ví da biológica" do ${ }^{35} \mathrm{~S}$, embora pareça ser semelhante à do ${ }^{15} \mathrm{~N}$, (48 horas) com participação predominante de ${ }^{35} \mathrm{~S}$ de origem endógena.

Apōs termos discutido isoladamente o efeito da ingestão do feijão e de suas proteinas sobre a excreção de nitrogênio e enxofre, apresentamos ägora a Figura 8, que reune os re sultados da eliminação desses elementos, diferenciados de acordo com a sua origem, em endógena e exógena.

Visualizamos a elevada excreção de nitrogênio e de enxofre, pelos animais que ingeriram a ração contendo o feijão integral, superior a $30 \%$ do ingerido. As fezes coletadas 12 horas após o início da ingestão dessa fonte protéica, apresentaram um teor de ${ }^{15} \mathrm{~N}$ e uma atividade do ${ }^{35} \mathrm{~S}$ correspondente a apro ximadamente $1 / 3$ do ingerido, que consideramos ser proveniente quase que exclusivamente do prōprio feijão. Evidenciamos, assim, paralelamente à excreção de nitrógênio e enxofre exógeno, uma elevada perda de material endögeno.

A ingestão da fração albuminica provocou uma excreção de nitrogênio e enxofre menor, da ordem de aproximadamente $20 \%$ do ingerido, havendo participação significativa tanto de fontes exogēnas como endógenas.

observamos finalmente que a ingestão da ração contendo a globulina Gl, provocou uma perda fecal muito reduzida, inferior atē à eliminação dos animais sob a ração de caseina. Es 

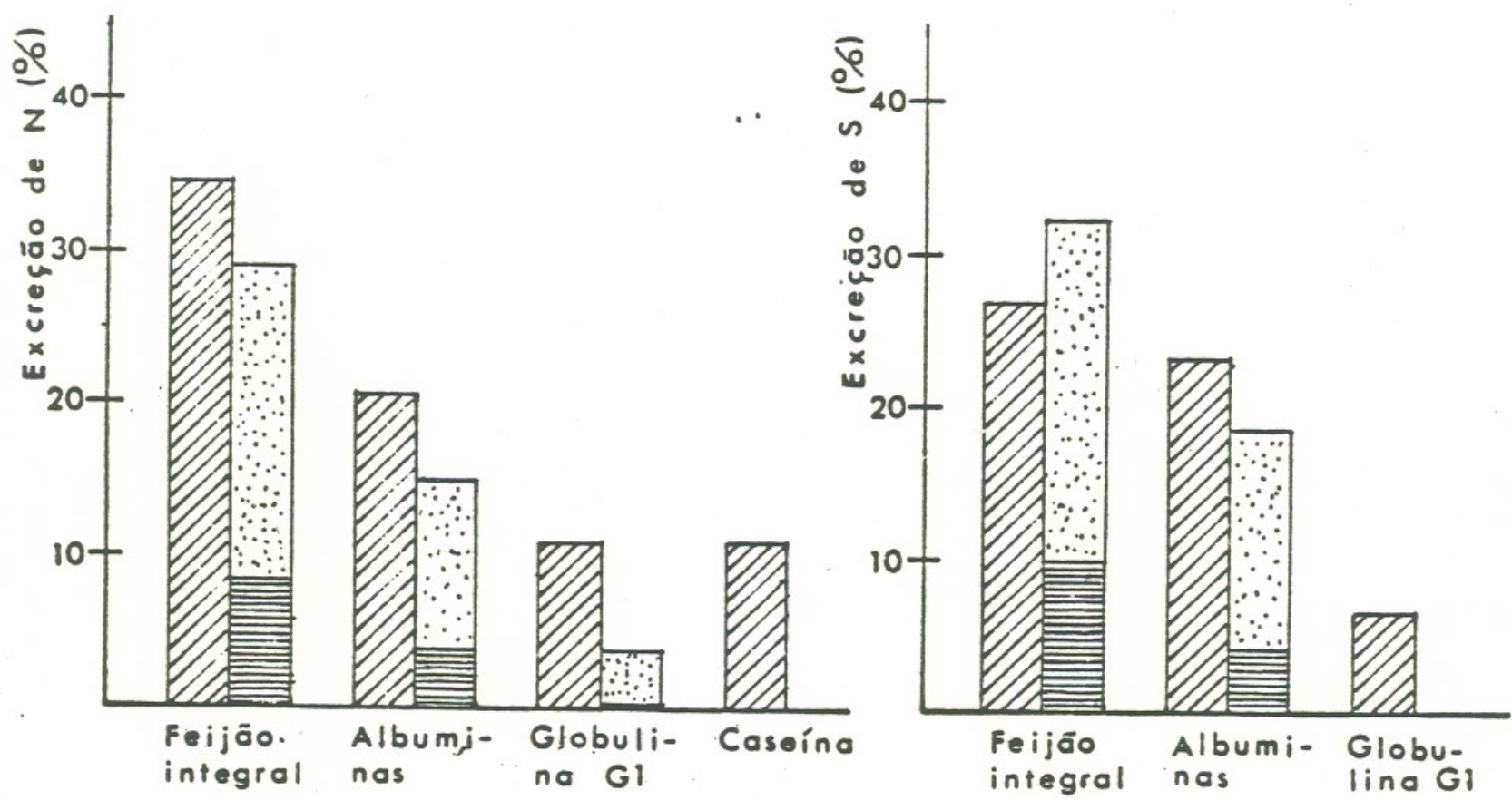

FIGURA 8 - Efeito da ingestão de rações contendo feijão integral, albuminas ou globulina Gl, marcados isotopica mente, sobre a excreção de nitrogênio e enxofre.

nitrogênio total $\left(14 \mathrm{~N}+{ }^{15} \mathrm{~N}\right)$ ou enxofre quimico.

害 nitrogênio $\left({ }^{15} \mathrm{~N}\right)$ ou enxofre $\left({ }^{35} \mathrm{~S}\right)$ nas primeiras 12 horas (exögeno).

nitrogênio $\left({ }^{15} \mathrm{~N}\right)$ ou enxofre $\left({ }^{35} \mathrm{~S}\right)$ na fase de "equilïbrio" (endógeno + exōgeno). 
ta reduzida excreção fecal, embora possa estar subestimada devi do a relativa "desnutrição" dos animais que ingeriram essa fonte protēica, mostram mais uma vez não haver problemas de digestibilidade e (ou) absorção; o nitrogênio e enxofre excretados provinham principalmente de fontes endögenas. 
9 - CONCLUSÕES

9.1 - O feijão integral bem como as suas frações protéicas isoladas mostraram um aproveitamento biológico redu zido.

A globulina Gl tem elevada digestibilidade, mas reduzidos indices de "NPR" e "Ganhos de Peso". O reduzí do aproveitamento da globulina Gl isolada não é causa do por um impedimento na sua hidrólise enzimática "in vivo" •

As frações, albuminica e glutelinica são as mais interessantes sob ponto de vista nutricional, ten do apresentado os melhores aproveitamentos biológicos, apesar de sua digestibilidade relativamente baixa.

9.2 - A ingestão de feijão integral provocou elevada excreção de matéria e nitrogênio fecais, 3-4 vezes superior àquela provocada pela ingestão da ração controle de caseina, enquanto as frações protéicas isoladas, causaram apenas um discreto aumento na excreção. Exis te uma relação direta entre o teor de fibra proveniente do feijão e a excreção fecal de $\mathrm{N}$, o que su- 
gere, uma complexação da proteina, com esses componen tes, tornando-a inaproveitável ao organismo animal, ou um incremento do $\mathrm{N}$ excretado por via endógena,.

9.3 - Em ensaios empregando isótopos do nitrogênio, demonstramos que a ingestão de feijões cozidos causou uma excreção de nitrogênio proveniente do próprio feijão, 10 vezes superior àquela provocada pela ingestão da globulina, acompanhada de uma alta excreção de nitrogênio endógeno, sendo a soma equivalente a $34 \%$ do nitrogênio ingerido.

9.4 - O nitrogênio fecal decorrente da ingestão da globulina Gl, parece ser quase exclusivamente de origem endōgena, apesar desta excreção ter pouco significado devido à reduzida excreção de material nitrogenado (mä ximo 10\%).

9.5 - A ingestão da ração à base de albuminas, provocou nos animais uma excreção fecal com participação significa tiva tanto do nitrogênio exógeno como endógeno, sendo a excreção total de nitrogênio de $20 \%$.

9.6 - A excreção de ${ }^{35} \mathrm{~S}$ pelos animais alimentados com rações à base de feijão integral ou suas frações protéi cas isoladas, mostrou um perfil semelhante à excreÇão de ${ }^{15} \mathrm{~N}$, embora em niveis levemente superiores. 
o estudo da digestibilidade e do aproveitamento bioló gico do feijão (Phaseolus vulgaris, L.), variedade Carioca e de suas principais frações protēicas foi realizado em ensaios biolögicos com ratos, após tratamento tērmico adequado (cocção).

A metodologia convencional, baseada no "Ganho de Peso" e na razão entre $\circ \mathrm{N}$ ingerido e excretado, seguiu-se uma tēcnica utilizando feijões e suas frações protēicas previamente marcadas com ${ }^{15} \mathrm{~N}$ e ${ }^{35} \mathrm{~s}$.

A ingestão das rações causou respostas diferentes nos animais, especificos para cada fonte protēica.

Os anima,is alimentados com o feijão integral tiveram reduzido aproveitamento biolögico e excretaram $34 \%$ do nitrogênio ingerido, sendo este valor 3-4 vezes superior ao causado pe la ingestão da ração controle de caseina. As frações, albumini cas e glutelinicas, apresentaram valores de "NPR" e "Ganhos de Peso" superiores, apesar de sua relativa baixa digestibilidade (70-80\%). A globulina Gl, altamente digerivel (92\%) teve uma utilização biológica muito reduzida; não permitindo o crescimen to dos animais.

O ensaio biológico do feijão e de suas proteinas, marcados isotopicamente, permitiu diferenciar a origem do nitrogênio e do enxofre fecal, se endōgena ou exógena. A concentração de ${ }^{15} \mathrm{~N}$ em excesso, determinado nas fezes 12 horas após o ini- 
cio da ingestão das rações marcadas, consideramos ser de origem exógena, sendo esses valores interpretados comparativamente. A ingestão de feijões cozidos causou nos animais uma excreção de nitrogênio proveniente do prōprio feijão, 10 vezes superior à provocada pela ingestão da globulina Gl, que aliada à elevada perda de nitrogênio endógeno, totalizou o equivalente a $34 \%$ do nitrogênio ingerido. Ratos alimentados com a globulina Gl excretaram nas primeiras 12 horas apenas quantidades muito reduzi das de ${ }^{15} \mathrm{~N}$, e mesmo na fase de equilibrio (40-6\% dia de inges tão da ração marcada) quando $\circ{ }^{15} \mathrm{~N}$ excretado corresponde ao e xōgeno + endógeno jā marcado, a perda de $\mathrm{N}$ total não ultrapassou $10 \%$ do ingerido.

A ingestão da fração albuminica, por sua vez, causou uma eliminação de $20 \%$ do $\mathrm{N}$ total ingerido, com participação tan to do $\mathrm{N}$ exógeno como endögeno.

A interpretação dos resultados baseados na eliminação do enxofre e de seu radioisótopo ${ }^{35} \mathrm{~s}$, mostrou um perfil de excreção semelhante ao observado para $\circ{ }^{15} \mathrm{~N}$, embora em niveis levemente superiores. 
SUMMARY

Studies with growing rats were carried out to determine the digestibility, and nutritive value of beans (Phaseolus vulgaris, L.) Carioca variety, and their major protein fractions, after proper heat treatment in order to inactivate the antiphysiological factors.

The conventional method based on weight gain and the relation between the ingested and excreted nitrogen was followed by a balance technique, employing either whole beans or their protein fractions, previously labeled with ${ }^{15} \mathrm{~N}$ and ${ }^{35} \mathrm{~S}$.

The ingestion of the diets showed different nutritive responses, which were specific for each of the diets.

Low biological value and digestibility were observed by rats fed on whole bean-containing diets, and as a consequence an excretion of $34 \%$ of the ingested nitrogen was noted. This value was 3-4 times higher than the one excreted by the casein-control animals. Higher values of "weight gain" and NPR were obtained with the albumin and glutelin based diets, although their digestibilities were relatively low (70-80\%). The globulin Gl was highly digestible $(92 \%)$ nevertheless it appeared to have very low nutritional values and did not allow the growth of rats.

The biological assay with isotopically labeled beans and proteins, allowed to differenciate the origin of fecal nitrogen and sulfur, as exogenous or endogenous. The concentration 
of ${ }^{15} \mathrm{~N}$ in excess, which appeared in the feces 12 hours after the first ingestion of the labeled diets, was considered to be of exogenous origin; these values can be interpreted comparatively. The ingestion of the cooked whole beans promoted an excretion of exogenous nitrogen, 10 times higher than that excreted by the rats on the globulin Gl diet, which with the high excretion of endogenous nitrogen, totalized $34 \%$ of the ingested one. Rats fed on the globulin Gl diet excreted, in the first 12 hours, anly small amounts of ${ }^{15} \mathrm{~N}$, even in the steady-state $(4 \%-6 \%$ th day on feeding the labeled diet), when the excreted ${ }^{15} \mathrm{~N}$ corresponded to both, exogenous and labeled endogenous excretion reached, the maximum loss (about $10 \%$ of the ingested total nitrogen). The feeding of albumin based diets stimulated an excretion of $20 \%$ of the ingested nitrogen, due to exogenous and endogenous origin.

The interpretation of the results based on the balance of total sulfur and their radioactive isotope $\left({ }^{35} \mathrm{~S}\right)$ showed an excretion pattern, similar to that of the ${ }^{15} \mathrm{~N}$, although in absolute values (of excretion) it was a little higher than that representing the nitrogen loss. 
ANTUNES, P.L. \& SGARBIERI, V.C. - Influence of time and conditions of storage on technological and nutritional properties of a dry bean (Phaseolus vulgaris, L.) variety Rosinha G2. J. Food Sci., Chicago, 44:1703-6, 1979.

ANTUNES, P.I. \& SGARBIERI, V.C. - Effect of heat treatment on the toxicity and nutritive value of dry bean (Phasecius vulgaris, var. Rosinha G2) proteins. J.Agric. Food Chem., Washington, 28:935-8, 1980.

ANTUNES, P.I.; SGARBIERI, V.C.; GARRUTI, R.S. - Nutrification of dry beans (Phaseolus vulgaris) by methionine infusion. J. Food Sci., Chicago, 44:1302-5, 1979.

ARTZ, W.E.; BISHOP, P.D.; DUNKER, A.K.; SCHANUS, G.; SWANSON, B.G. - Interaction of synthetic proanthocyanidin dimer and trimer with bovine serum albumin and purified bean globulin fraction G-1. J.Agric. Food Chem., Washington, 35:417-21, 1987.

ASP, N.-G.; JOHANSSON, C.-G.; HALLMER, H.; SILJESTROM, M. Rapid enzymatic assay of insoluble and soluble dietary fiber. J.Agric. Food Chem., Washington, 31:476-82, 1983.

* De acordo com as normas preconizadas pela ASSOCIAÇÃO BRASIIEIRA DE NORMAS TECNICAS (ABNT). As abreviaturas dos títulos de periódicos seguem 0 Chemical Abstracts Service Source Index (CASSI) Columbus, 1985. 
ASSOCIATION OF OFFICIAL ANALYTICAL CHEMISTS - Official methods of analysis, 12.ed. Washington, 1975. p.927-8.

AW, T-L. \& SWANSON, B.G. - Influence of tannin on phaseolus vulgaris protein digestibility and quality. J. Food Sci., Chicago, 50:67-71, 1985 .

BARKER, R.D.J.; DERBYSHIRE, E.; YARWOOD, A.; BOULTER, D. Purification and characterization of the major storage proteins of phaseolus vulgaris seeds, and their intracellular and cotyledonary distribution. Phytochemistry, New York, 15: $751-7,1976$.

BENDER, A.E. \& MOHAMMADIHA, H. - Low digestibility of legume nitrogen. Proc. Nutr. Soc., Cambridge, 40:66A, 1981.

BHATTY, R.S. - Albumin proteins of eight edible grain legume species: electrophoretic patterns and amino acid composition. J. Agric. Food Chem., Washington, 30:620-2, 1982.

BICUDO, M.H. - Efeito da casca de feijão (Phaseolus vulgaris) na utilização da caseina. Belo Horizonte, 1978. 70 p. |Dissertação Mestrado - Universidade Federal de Minas Gerais|.

BOONVISUT, S. \& WHITAKER, J.R. - Effect of heat, amylase, and disulfide cleavage on the in vitro digestibility of soybean proteins. J.Agric. Food Chem., Washington, 24:1130-5, 1976.

BRADBEAR, N. \& BOULTER, D. - The use of enzymic hydrolysis in vitro to study the digestibility of some phaseolus seed proteins. Qual. Plant.-Foods Hum. Nutr., The Hague 34:3-13, 1984 . 
BRAY, G.A. - A simple efficient liquid scintillator for counting aqueous solutions in a liquid scintillation counter. Anal. Biochem., Baltimore, 1:279-85, 1960.

BRESSANI, R. \& ELIAS, L.G. - Evaluación de la calidad protéinica de varias leguminosas de grano usando diversos mētodos biológicos. Arch. Latinoam. Nutr., Caracas, 26:325-39, 1976.

BRESSANI, R. \& ELIAS, L.G. - Relación entre la digestibilidad y el valor proteinico del frijol comun (Phaseolus vulgaris). Arch. Latinoam. Nutr., Caracas, 34:189-97, 1984.

BRESSANI, R.; ELIAS, L.G.; BRAHAM, J.E. - Reduction of digestibility of legume proteins by tannins. J. Plant. Foods, London, $\underline{4}: 43-55,1982$.

BRESSANI, R.; ELIAS, L.G.; MOLINA, M.R. - Estudios sobre la digestibilidad de la proteina de varias especies de legumino sas. Arch. Latinoam. Nutr., Caracas, 27:215-31, 1977.

BRESSANI, R.; ELIÁS, L.G.; VALIENTE, T. - Effect of cooking and of amino acid supplementation on the nutritive value of black beans. (Phaseolus vulgaris, L.). Br. J. Nutr., London, 17: $69-78,1963$.

CALLOWAY, D.H. \& KRETSCH, M.J. - Protein and energy utilization in men given a rural Guatemalan diet and egg formulas with and without added oat bran. Am. J. Clin. Nutr., Bethesda, 31: $1118-26$, 1978 .

CHANG, K.C. \& SAITERLEE, L.O. - Isolation and characterization of the major protein from Great Northern Beans (Phaseolus vulgaris). J. Food Sci., Chicago, $\underline{46}: 1368-73, .1981$. 
COSTA DE OLIVEIRA, A. \& SGARBIERI, V.C. - The influence of rat endogenous nitrogen excretion on the assessment of bean protein quality. J. Nutr. Sci., Vitaminol., Tokyo, 32:425-39, 1986b.

COSTA DE OLIVEIRA, A.; SGARBIERI, V.C. - Effects of diets ' containing dry beans (Phaseolus vulgaris, L.) on the rat excretion of endogenous nitrogen. J. Nutr., Philadelphia, $\underline{116}: 2387-92$, $1986 \mathrm{a}$.

DA COSTA, L.R.; CROFT, D.N.; CREAMER, B. - Protein loss and cell loss from the small-intestinal mucosa. Gut, Iondon, 12:179-83, 1971.

DERBYSHIRE, E.; WRIGHT, D.J.; BOULTER, D. - Review. Legumin and vicilin, storage proteins of legume seeds. Phytochemistry, New York, 15:3-24, 1976.

DESHPANDE, S.S. \& NIELSEN, S.S. - Nitrogenous constituents of selected grain legumes. J. Food Sci., Chicago, 52:1321-5, 1987a.

DESHPANDE, S.S. \& NIELSEN, S.S. - In vitro enzymatic hydrolysis of phaseolin, the major storage protein of phaseolus vulgaris, L. F. Food Sci., Chicago, 52:1326-9, 1987b.

DESHPANDE, S.S. \&,NIEISEN, S.S. - In vitro digestibility of dry bean (Phaseolus vulgaris, L.) proteins: the role of heat-stabile protease inhibitors. J. Food Sci., Chicago, $\underline{52}$ : $1330-4,1987 \mathrm{c}$.

DESHPANDE, S.S. \& PRADESH, A. - Tannin analysis of food products. CRC Crit. Rev. Food Sci. Nutr., Cleveland, 24:401-49, 1986.

DESHPANDE, S.S.; SATHE, S.K.; SALUNKHE, D.K.; CORNFORTH, D.P. - Effects of dehulling on phytic acid, polyphenols, and enzyme inhibitors of dry beans (Phaseolus vulgaris, L.). J. Food Sci., Chicago, 47:1846-50, 1982 .

DUBOIS, M.; GILLES, K.A.; HAMILTON, J.K.; REBERS, D.A.; SMITH, F. - Colorimetric methods of determination of sugars and related substances. Anal. Chem., Washington, 28:350-6, 1956 , 
DURIGAN, J.F.; SGARBIERI, V.C.; BULISANI, E.A. - Protein value of dry bean cultivars: factors interfering with biological utilization. J.Agric. Food Chem., Washington, 35:694-8, 1987 .

DREYER, J.J. \& van der WALT, W.H. - A system for assessment of dietary protein quality based on an updated version of the nitrogen metabolism method using young rats.

1. Determination of digestibility. S. Afr. J. Sci., Johannesburg, 80:417-23, 1984 .

ELIAS, L.G.; DE FERNANDEZ, D.G.; BRESSANI, R. - Possible effects of seed coat polyphenolics on the nutritional quality of bean protein. J. Food Sci., Chicago, 44:524-7, 1979.

ERICSON, M.C.; CHRISPEELS, M.J. - Isolation and characterization of glucosamine - containing storage glycoproteins from the cotyledons of Phaseolus aureus. Plant Physiol., Bethesda, 52:98-104, 1973 .

EVANS, R.J. \& BAUER, D.H. - Studies of the poor utilization by the rat of methionine and cystine in heated dry bean seed (Phaseolus vulgaris). J.Agr. Food Chem., Washington, 26: $779-84,1978$.

EVANS, R.J.; BAUER, D.H.; SISAK, K.A.; RYAN, P.A. - The availability for the rat of methionine and cysteine in dry bean seed (Phaseolus vulgaris). J. Agric. Food Chem., Washington, 22:130-3, 1974 .

FAIRWEATHER-TAIT, S.J.; GEE, J.M.: JOHNSON, I.T. - The influence of cooked kidney beans (Phaseolus vulgaris) on intestinal cell turnover and faecal nitrogen excretion in the rat. Br. J. Nutr., London, 49:303-12, 1983. 
FERNANDEZ, D.G. - Estudio sobre las posibles relaciones entre los pigmentos presentes en la cáscara de frijol y el valor nutritivo de este. Apud BICUDO, M.H. - Efeito da casca de feijão (Phaseolus vulgaris) na utilização da caseina. Belo Horizonte, 1978. 70p. |Dissertação Mestrado - Universidade Federal de Minas Gerais|.

FINARDI FILHO, F. \& LAJOLO, F.M. - Identificação eletroforética de inibidor de alfa-amilase em gëis de poliacrilamida-amilopectina. Ciênc. Tecnol. Aliment., Campinas, 20:21-32, 1982 .

GALLAHER, D. \& SCHNEEMAN, B.O. - Nutritional and metabolic response to plant inhibitors of digestive enzymes. Adv. Exp. Med. Biol., New York, 177:299-319, 1984.

GRAHAM, G.G.; MORALES, E.; PLACKO, R.R.; MaC LEAN, Jr. W.C. - Nutritive value of brown and black beans for infants and small children. Am. J. Clin. Nutr., Bethesda, 32:2362-6, 1979.

GREEN, G.M. \& NASŚET, E.S. - Role of dietary protein in rat pancreatic enzyme secretory response to a meal. J. Nutr.,' Philadelphia, 113:2245-52, 1983.

GRIFFITHS, D.W. \& MOSELEY, G. - The effect of diets containing field beans of high or low polyphenolic content on the activity of digestive enzymes in the intestines of rats. J. Sci. Food Agric., London, 31:255-9, 1980.

HERNANDEZ-INFANTE, M.; HERRADOR-PENA, G.; SOTELO-LOPEZ, A. Nutritive value of different beans (Phaseolus vulgaris) supplemented with methionine. J.Agric. Food Chem., Washington, 27:965-8, 1979 . 
HERRIDGE, D.V.; ATKINS, C.A.; PATE, J.S.; RAINBIRD, R.M. - Allantoin and allantoic acid in the nitrogen economy of the Cowpea (Vigna unguiculata |L.| Walp). Plant Physiol., Bethesda, 62:495-8, 1978.

INSTITUTE OF LABORATORY ANIMAL RESOURCES. Committee on laboratory animal diets. a report. Nutr. Abstr. Rev. Ser. B, Slough, 49:413-9, 1979 .

ISHINO, K. \& ORTEGA, M.L. Fractionation and characterization of major reserve proteins from seeds of Phaseolus vulgaris. J. Agric. Food Chem., Washington, 23:529-33, 1975.

IVAN, M. \& BOWLAND, J.P. - Digestion of nutrients in the small intestine of pigs fed diets containing raw and autoclaved faba beans. Can. I. Anim. Sci., Ottawa, 56:451-6, 1976.

JAFFE, W.G. - Protein digestibility and trypsin inhibitor activity of legume seeds. Proc. Soc. Exp. Biol. Med., New York, 75: 219-20, 1950 .

JAFFE, W.G. - Hemagglutinins (lectins). In: LIENER, I.E. Toxic constituents of plant foodstuffs. 2.ed., New York, Academic Press, 1980. p.73-102.

KAKADE, M:L. \& EVANS, R.J. - Growth inhibition of rats fed raw navy beans (Phaseolus vulgaris). J. Nutr., Philadelphia, 90:191-8, 1966 .

KAKADE, M.L.; RACKIS, J.J.; MC GHEE, J.E.; PUSKI, G. - Determination of trypsin inhibitor activity of soy products: A collaborative analysis of an improved procedure. Cereal Chem., Saint-Paul, 51:376-82, 1974 .

KANTHA, S.S. \& ERDMAN JR, J.W. - Legume carotenoids. CRC Crit.

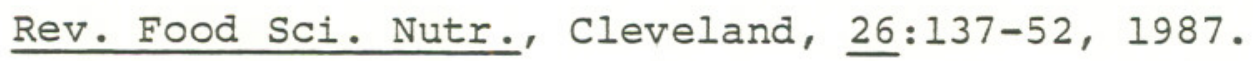

KOEHLER, R.; PAHLE, T.; GEBHARDT, G. - Absorption and utilisation of differently structured isolated proteins by cats. Arch. Tierernaehr., Berlin, 34:111-21, 1984. 
KRAWIELITZKI, K. - The compartment model as a method of estimating characteristic data on the resorption kinetics of amino acids. (2) Uses of the compartment model and discussion of results. Arch. Tierernaehr., Berlin, 22:563-591, 1972.

KRAWIELITZKI, K. \& BOCK, H.-D. - Problems of nitrogen metabolism in monogastric, animals. Arch. Tierernaehr., Berlin, 26:83$98,1976$.

KRAWIELITZKI, K.; SCHADEREIT,R.; VOELKER, T.; REICHEL, K. - Dependence of the metabolic fecal amino acids on the amino acid content of the feed. 1. Metabolic fecal amino acids of rats fed with maize. Arch. Tierernaehr., Berlin, 31: $433-46,1981$.

KRAWIELITZKI, K. \& TIM, E. - Tracerversuche mit ${ }^{15_{\mathrm{N}} \text {-markiertem }}$ Weizen zur Bestimmung des endogenen und exogenen faekalen N-Anteils. Arch. Tierernaehr., Berlin, 28:155-64, 1978.

KREUZER, M. \& KIRCHGESSNER, M. - Effects of type and quantity of starch in the ration on apparent and true $\mathrm{N}$ digestibility and on $\mathrm{N}$ balanće of sheep. Arch. Tierernaehr., Berlin, 10: 723-31, . 1985.

KRUG, F.J.; BERGAMIN FILHO, H.; ZAGATTO, E.A.S.; JOERGENSEN, S.S. - Rapid determination of sulphate in natural waters and plant digests by continuous flow injection turbidimetry. Analyst, London, 102:503-8, 1977.

KRUG, F.J.; ZAGATTO, E.A.G.; REIS, B.F.; BAHIA FILHO, O.; JACIN THO, A.O.; JOERGENSEN, S.S. - Turbidimetric determination of sulphate in plant digests and natural waters by flow injection analysis with alternating streams. Anal. Chim. Acta, Amsterdam, 145:179-87, 1983. 
LAJOLO, F.M. - Inibidor de amilase do (Phaseolus vulgaris): estudo bromatológico. São Paulo, 1977, 133p. |Tese de Livre-Docência - Faculdade de Ciências Farmacêuticas - Universida de de São Paulo|.

LAJOLO, F.M. \& FINARDI FILHO, F. - Purificação do inibidor de alfa-amilase do feijão preto (Phaseolus vulgaris) var. Rico 23. Ciênc. Tecnol. Aliment., Campinas, $\underline{4}: 1-11,1984$.

LANFER MARQUEZ, U.M. - Digestibilidade e caracteristicas bioquimicas de proteinas do Phaseolus vulgaris, L., são Paulo, 1979, 108p. |Dissertação Mestrado - Faculdade de Ciências Farmacêticas - Universidade de São Paulo|.

LANFER MARQUEZ, U.M. \& LAJOLO, F.M. - Composition and digestibility of albumin, globulin, and glutelins from Phaseolus vulgaris. J. Agric. Food Chem., Washington, 29:1068-74, 1981.

LASKOWSKI JR, M. \& KATO, I. - Protein inhibitors of proteinases. Annu. Rev.Biochem., Palo Alto, 49:593-626, 1980.

LAURENA, A.C.; GAŔCIA, V.V.; MENDOZA, E.M.T. - Effects of soaking in aqueous acidic and alkali solutions on removal of polyphenols and in vitro digestibility of cowpea. Qual. Plant.-Plant Foods Hum. Nutr., The Hague, 36:107-18, 1986.

LIEBERT, F. \& GEBHARDT, G. - Investigations into the influence of cellulose and various kinds of starch in the feed on nitrogen metabolization in growing pigs. Arch. Anim. Nutr., Berlin, 36:35-44, 1986.

LIENER, I.E. - The photometric determination of hemagglutinating activity of soyin and crude soybean extracts. Arch. Biochem. Biophys., New York, 54:223-31, 1955.

LIENER, I.E. - Legume toxins in relation to protein digestibility - a review. J. Food Sci., Chicago, 41:1076-81, 1976. 
IIENER, I.E. - Trypsin inhibitors: Concern for human nutrition or not ? J. Nutr., Philadelphia, 116:920-3, 1986.

LIENER, I.E. \& THOMPSON, R.M. - In vitro and in vivo studies on the digestibility of the major storage protein of the navy bean (Phaseolus vulgaris). Qual. Plant. - Plant Foods Hum. Nutr., The Hague, 30:13-25, 1980.

LOWRY, O.H.; ROSEBROUGH, N.J.; FARR, A.L.; RANDALL, R.J. Protein measurement with the.Folin phenol reagent. J. Biol. Chem., Baltimore, 193:265-75, 1951.

MA, Y. - Improvement of nutritive value of dry bean seeds (Phaseolus vulgaris, L.), (s.1.p.). 1977. 105p. |Tese de Doutoramento - University of Wisconsin - Madison|.

MCLEESTER, R.C.; HALL, T.C.; SUN, S.M.; BLISS, F.A. - Comparison of globulin proteins from phaseolus vulgaris with those from Vicia faba. Phytochemistry, New York, 2: 85-93, 1973.

MENEZES, E.W. \& LAJOLO,. F.M. - Inhibition of starch digestion by a black bean $\alpha$-amylase inhibitor in normal and diabetic rats. Nutr. Rep. Int., Los Altos, 36:1185-95, 1987.

MIFLIN, B.J., ed. Amino acids and derivatives, New York, Academic Press, 1980. 670p. |The Biochemistry of plants, v.5|.

MITCHELI,H.H. - A method of determining the biological value of protein. J. Biol. Chem., Baltimore, 58:873-903, 1924.

MITCHELL,H.H. \& BERT, M.H. - The determination of metabolic fecal nitrogen. J. Nutr., London, 52:483-97, 1954. 
MORAES e SANTOS, T. \& DUTRA DE OLIVEIRA, J.F. - Valor nutritivo de frações protéicas isoladas de feijão (Phaseolus vulgaris). Arch.Latinoam. Nutr., Caracas, 22:547-60, 1972.

NASSET, E.S. - Amino acid homeostasis in the gut lumen and its nutritional significance. World Rev. Nutr. Diet., New York, $\underline{14}: 134-153$, 1972 .

NASSET, E.S. \& JU, J.S. - Mixture of endogenous and exogenous protein in the alimentary tract. J. Nutr., Philadelphia, 74: $461-5,1961$.

NATIONAL RESEARCH COUNCIL. Nutrient requirements of the laboratory rat. In: NUTRIENT requirements of laboratory animals. 2. ed. Washington, National Academy of Sciences, 1972. p.56-93. (Nutrient requirements of domestic animals, 10).

NAVARRETE, D.A. \& BRESSANI, R. - Protein digestibility and protein quality of common beans (Phaseolus vulgaris) fed alone and with maize, in adult humans using a short-term nitrogen balanće assay. Am. J. Clin. Nutr., New York, 34: $1893-1898,1981$.

NETER, J.; WASSERMAN, W.; KUTNER,M.H. - Applied linear statistical models: regression, analysis of variance, and experimental designs. 2.ed. Homewood, Richard D. Irwin, 1985. 1127p.

PADHYE, V.W. \& SALUNKHE, D.K. - Biochemical studies on black gram (Phaseolus mungo L.) seeds: amino acid composition and subunit constitution of fractions of the proteins. J. Food Sci., Chicago, 44:606-14, 1979. 
PARTRIDGE, I.G.; SIMON, O.; BERGNER, U. - The passage and absorption of dietary and endogenous nitrogen in different regions of the digestive tract of rats given a single meal of ${ }^{15} \mathrm{~N}$ - labelled barley. Arch. Tierernaehr., Berlin, 35: $163-73,1985$.

PROKSCH, G. - Routine analysis of nitrogen-15 in plant material by mass-spectrometry. Plant Soil, The Hague, $\underline{31}(2): 380-4$, 1969.

PUSZTAI, A. \& PALMER,R. - Nutritional evaluation of kidney beans (Phaseolus vulgaris): the toxic principle. J. Sci. Food Agric., London, 28:620-623, 1977.

PUSZTAI, A. \& WATT, W.B. - The isolation and characterization of a major antigenic and non-haemagglutinating glycoprotein from Phaseolus vulgaris. Biochim. Biophys. Acta, Amsterdam, $\underline{20}: 413-431$, 1970 .

REDDY, N.R.; PIERSON, M.D.; SATHE, S.K.; SALUNKHE, O.K.-Chemical, nutritional and physiological aspects of dry bean carbohydrates - a review. Food Chem., Barking, 13:25-68, 1984.

RERAT, A.P.; VAUGELADE, P.; VILLIERS, P. - Digestion and absorption of nutrients in the pig. In: Low, A.G., Partridge, I.G. Current concepts of digestion on absorption in pigs. Nird, Reading, Techn. Bull. no 3, 1980. Apud: KRAWIELITZKI, K., SCHADEREIT, R.; ZEBROWSKA, T.; WÜNSCHE, J.; BOCK, H.D. Arch. Tierernaehr., Berlin, 34:1-18, 1984.

RICHARDSON, M. - Protein inhibitors of enzymes. Food Chem., Barking, $\underline{6}: 235-53$, 1980-1981.

ROGERS, A.E. - Nutrition. In: BAKER, H.J.; LINDSEY, J.R.; WEISBROTH, S.H. - The laboratory rat, New York, Academic Press, 1979. v.1, p.123-152. 
ROMERO, R. \& RYAN, D.S. - Susceptibility of the major storage protein of the bean, Phaseolus vulgaris L., to in vitro enzymatic hydrolysis. J.Agric. Food Chem., Washington, $\underline{26}: 784-8,1978$.

ROMERO, J.; SUN, S.M.; MCLEESTER, R.C.; BLISS, F.A.; HALL, T.C. - Heritable variation in a polypeptide subunit of the major storage protein of the bean, Phaseolus vulgaris, I. Plant Physiol., Bethesda, 56:776-9, 1975.

RONNENCAMP, P.R. - The effect of tannins on nutritional quality of dry beans. Phaseolus vulgaris. (s.1.p.), 1977. 52p. |Tese de Doutoramento - Purdue University|.

ROSALES ARZU, A.M. - Estudio sobre la calidad proteinica del frijol y la de tres fracciones derivadas por solubilidad diferencial in niños preescolares. Apud BRESSANI, R. et al. Estudios sobre la digestibilidad de la proteina de varias especies de leguminosas. Arch. Latinoam. Nutr., Caracas, 27:215-31, 1977 .

SALTER, D.N. - Thé influence of gut micro-organisms on utilization of dietary protein. Proc. Nutr. Soc.' Cambridge, 32:65-71, 1983.

SANDARADURA, S.S. \& BENDER, A.E. - The effect of cooked legumes on mucosal cell turnover in the rat. Proc. Nutr. Soc., Cambridge, 43:89A, 1984 .

SARWAR, G. \& PEACE, R.W. - Comparisons between true digestibility of total ritrogen and limiting amino acids in vegetable proteins fed to rats. J. Nutr., Philadelphia, 116:1172-84, 1986. 
SATHE, S.K. \& SALUNKHE, D.K. - Solubilization and electrophoretic characterization of the Great Northern Bean (Phaseolus vulgaris, L.) proteins. J. Food Sci., Chicago, 46:82-7, 1981.

SATHE, S.K.; IYER, V.; SALUNKHE, D.K. - Functional properties of the Great Northern bean (Phaseolus vulgaris, L.) proteins. Amino acid composition, in vitro digestibility, and application to cookies. J. Food Sci., Chicago, 47:8-11, 15, 1982.

SCHROEDER; H.F. - Major albumins of Pisum cotyledons. J. SCi. Food Agric., London, 35:191-8, 1984.

SCHUBERT, K.R. - Enzymes of purine biosynthesis and catabolism in Glycine max. I. Comparison of activities with $\mathrm{N}_{2}$ fixation and composition of xylem exsudate during nodule development. Plant Physiol., Bethesda, 68:1115-22, 1981.

SEIDL, D.; JAFFE, M.; JAFFE, W.G. - Digestibility and proteinase inhibitory action of a kidney bean globulin. J.Agric.Food Chem., Washington, 17:1318-21, 1969.

SEMINO, G.A.; RESTÁAN, P.; CERLETTI, P. - Effect of bound carbohydrate on the action of trypsin on lupin seed glycoproteins. J.Agric. Food Chem., Washington, 33:196-9, 1985.

SGARBIERI, V.C.; ANTUNES, P.L.; ALMEIDA, L.D. - Nutritional evaluation of four varieties of dry beans. (Phaseolus vulgaris, L.). J. Food Sci., Chicago, 44:1306-8, 1979.

SGARBIERI, V.C.; CLARKE, E.M.W.; PUSZTAI, A. - Prcteolytic breakdown of kidney bean (Phaseolus vulgaris) storage proteins : Nutritional implications. J.Sci. Food Agric., London, 33 : 881-91, 1982 . 
SGARBIERI, V.C. \& WHITAKER, J.R. - Physical, chemical, and nutritional properties of common bean (Phaseolus) proteins. Adv. Food Res., New York, 28:93-166, 1982.

SINGH, U. - The inhibition of digestive enzymes by polyphenols of chick pea (Cicer arietinum L.) and pigeon pea (Cajanus cajan (L.) Millsp.). Nutr. Rep. Int., Los Altos, 29:74553, 1984 .

SLUMP, P. \& VAN BEEK, L. - Amino acids in feces related to digestibility of food proteins. In: FRIEDMAN, M., ed. Protein nutritional quality of foods and feeds. New York, Marcel Dekker, 1975. part 1, p. 67-78.

SOSULSKI, F.W. \& HOLT, N.W. - Amino acid composition and nitrogen to protein factors for grain legumes. Can. J. Plant Sci., Ottawa, 60:1327-1331, 1980.

SOUFFRANT, W.B.; DARCY-VRILLON, B.; CORRING, T.; LAPLACE, J.D.; KÖHLER, R.; GEBHARDT, G.; RERAT, A. - Recycling of endogenous nitrogen in the pig (preliminary results of a collaborative study). Arch'. Anim. Nutr., Berlin, 36:269-274, 1986.

SOUFFRANT, W.B.; KÖHLER, R.; GEBHARDT, G. - Investigations of the absorption of protein-linked $\mathrm{N}$ and synthetic methionine in the small intestines of pigs. Arch. Tierernaehr. Berlin 31: $609-17,1981$.

SUN, S.M. \& HALL, T.C. - Solubility characteristics of globulins from Phaseolus seeds in regard to their isolation and characterization. J.Agric. Food Chem., Washington, 23:1849, 1975 .

TAMIR, M. \& ALUMOT, F. - Carob tannins - Growth depression and levels of insoluble nitrogen in the digestive tract of rats. J. Nutr., London, 100:573-80, 1970. 
TRIPLETT, E.W. - Two indirect methods for detecting ureide synthesis by nodulated legumes. Plant Physiol., Bethesda, 81: $566-71,1986$.

TRIVELIN, P.C.O.; SALATI, E.; MATSUE, E! - Preparo de amostras para anālise de nitrogênio-15 por espectrometria de massa. Piracicaba, Cena, 1973, 4lp. (Boletim Técnico no 002).

VAINTRAUB, I.A. \& SAYANOVA, O. - Effect of kidney bean 7S protein on the proteolytic activity. of trypsin. Izo. Akad. Nauk. Mold. SSR Ser. Biol. Khim. Nauk, 3:24-27. Apud. Chem. Abstr., Columbus, 87:147840d, 1977.

VAINTRAUB, I.A.; SELIGER, P.; SHUTOV, A.D. - The action of pepsin on the reserve proteins of some leguminous seeds. Nahrung, Berlin, 23:15-21, 1979 .

ZEBROWSKA, T. \& LOW, A.G. - The influence of diets based on whole wheat, wheat flour and wheat bran on exocrine pancreatic secretion in pigs: J. Nutr., Philadelphia, 117:1212-16, 1987.

ZEBROWSKA, T.; SIMON, O.; MUENCHMEYER, R.; BERGNER, H. - Studies on the amino acid absorption and the secretion of endogenic amino acids into the gastro-intestinal tract of pigs. Arch. Tierernaehr, Berlin, 26:69-82, 1976.

ZIMMER, M.; BERGNER, N.; SIMON, O. - Absorption and incorporation of labelled amino acids in rats fed various protein sources 1. Absorption of $14 \mathrm{C}-$ leucine and $3 \mathrm{H}-$ glycine in rats after intragastric administration. Arch. Tierernaehr., Berlin, 25:311-26, 1975. 
12 - APENDICE

LISTA DE FIGURAS

\section{Figura}

1 - Curvas de peso de ratos alimentados com rações de caseina e proteinas do feijão (10\% de proteína)...........4 48

2 - Efeito da ingestão das rações contendo feijão integral ou suas proteỉnas isoladas, sobre a excreção fecal de maté ria seca e de nitrogênio....................69

3 - Excreção fecal de ${ }^{15} \mathrm{~N}$ ( $\%$ da ingestão médịa diäria), doze horas após o início da ingestão da ração marcada e na fase de equilibrio (48 ao 6 \% dia da experiência)....... 74

4 - Curvas de excreção fecal de ${ }^{15} \mathrm{~N}$ (\% da ingestão média diāria) dos animais ( $n=4)$ alimentados com feijão integral,

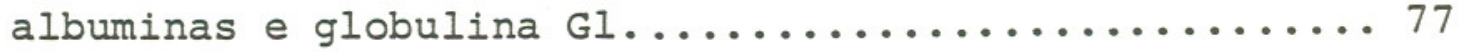

5 - Redução da concentração de ${ }^{15} \mathrm{~N}$ nas fezes, durante a fase de decaimento (6\%-12\% dia), dos animais alimentados com fei jão integral, albuminas e globulina Gl........... 78

6 - Curvas de excreção fecal de ${ }^{35} \mathrm{~S}$ (\% da ingestão média diària), dos animais ( $n=4)$ alimentados com feijão integral,

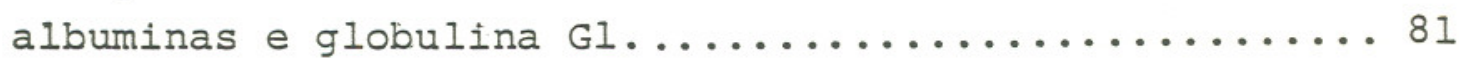




\section{Figura}

7 - Redução da atividade isotópica do ${ }^{35} \mathrm{~S}$ nas fezes, durante a fase de decaimento (6\%-12\% dia), dos animais alimentados com feijão integral, albumina e globulina Gl........ 82

8 - Efeito da ingestão de rações contendo feijão integral, albuminas ou globulina Gl, marcados isotopicamente, sobre a excreção de nitrogênio e enxofre............ 84 
IISTA DE TABELAS E QUADROS

\section{Tabela}

1 - Teor de nitrogênio total $\left({ }^{14} \mathrm{~N}+{ }^{15} \mathrm{~N}\right)$, nas fontes protéi cas e nas rações experimentais..................... 38

2 - Teor de ${ }^{15} \mathrm{~N}$ nas fontes protēicas e nas rações experimen -

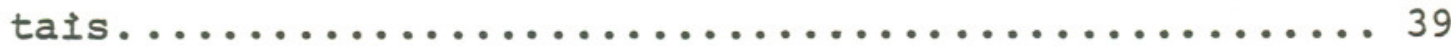

3 - Teor de enxofre total nas fontes protéicas e nas rações

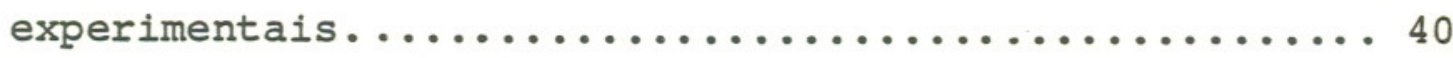

4 - Atividade do ${ }^{35} \mathrm{~S}$ nas fontes protēicas e nas rações experi

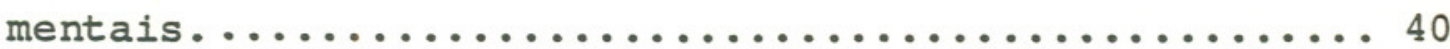

5 - Experiência 1. Digestibilidade e "NPR" (utilização protēica líquída) das proteinas isoladas do feijão. (Ensaio de 7 dias de duração) $\ldots \ldots \ldots \ldots \ldots \ldots \ldots \ldots \ldots . \ldots \ldots$

6 - Experiência 2. Digestibilidade e "NPR" (utilização protēica lîquida) do feijão, e do feijão suplementado com a fração albuminica. (Ensaio de 13 dias de duração)... 47

7 - Experiência 3. Digestibilidade e "NPR" (utilização protéica líquida) do feijão integral e de suas proteínas iso ladas. (Ensaio de 12 dias de duração)........... 51

8 - Experiência 3. Ensaio do feijão integral: Ingestão e ex creção fecal diārias de nitrogênio total $\left({ }^{14} \mathrm{~N}\right.$ e $\left.{ }^{15} \mathrm{~N}\right)$ e 15 
Tabela

9 - Experiência 3. Ensaio da fração albuminica: Ingestão e excreção fecal diārias de nitrogênio total $\left({ }^{14} \mathrm{~N}\right.$ e $\left.{ }^{15} \mathrm{~N}\right)$

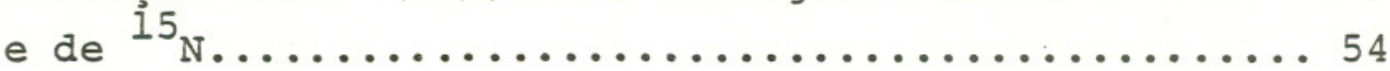

10 - Experiência 3. Ensaio da fração globulina Gl: Ingestão e excreção fecal diārias de nitrogênio total $\left({ }^{14} \mathrm{~N}\right.$ e $\left.{ }^{15} \mathrm{~N}\right)$

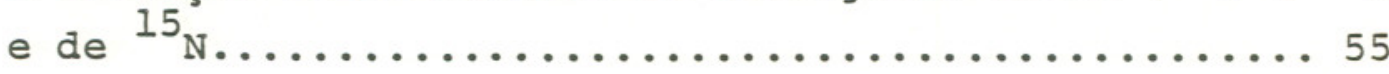

11 - Experiência 3. Ensaio do feijão integral: Ingestão e excreção fecal diărias de enxofre total e de ${ }^{35}$ S. .. 57

12 - Experiência 3. Ensaio da fração albuminica: Ingestão e excreção fecal diārias de enxofre total e de ${ }^{35}$ s. .. 58

13 - Experiência 3. Ensaio da globulina Gl: Ingestão e excreção fecal diärias de ${ }^{35}$ s................. 59

Quadro

I - Relação entre a excreção fecal e o teor de fibra da die

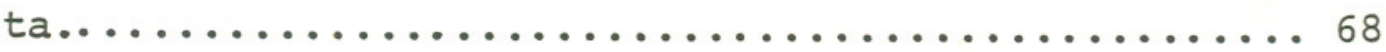

II - Diluição isotópica do ${ }^{15} \mathrm{~N}$ das rações pela passagem no trato gastro-intestinal dos animais.......... 72

III - Diluição isotópica do ${ }^{35}$ S das rações pela passagem no trato gastro intestinal dos animais. .......... 80 